F. med. Genet. (1965). 2, 48 .

\title{
Human Haemoglobins
}

\author{
E. R. HUEHNS* and E. M. SHOOTER
}

From Medical Research Council Group in Haemolytic Anaemia, University College Hospital Medical School and $\overrightarrow{\vec{\omega}}$ Department of Biochemistry, University College London, and Department of Genetics, Stanford University Medical Center, Palo Alt , California, U.S.A.

\section{I-Structure of Haemoglobin II-The Genetic Control of Haemoglobin Synthesis III-The Biosynthesis of Haemoglobin IV-Clinical Features of Abnormalities in Haemoglobin Synthesis}

During the past 15 years the study of the normal and abnormal human haemoglobins has advanced our understanding of the genetic control of protein synthesis and also provided an example of the various ways in which abnormalities of protein synthesis can cause disease. There have been a number of reviews on this subject (Itano, Bergren, and Sturgeon, 1956; Itano, 1957; Beaven and Gratzer, 1959; Lehmann and Ager, 1960; Bannerman, 196I; Hill, 196I ; Ingram, 196I ; Rucknagel and Neel, I96I; Baglioni, I963a; Jonxis, r963), and this review mentions only the more important early advances, but deals in more detail with those of present interest.

\section{I: STRUCTURE OF HAEMOGLOBIN}

Haemoglobins are large, complex, protein molecules, the function of which is to transport oxygen from the lungs to the tissues. Recent work by Perutz and his collaborators (Perutz, Rossman, Cullis, Muirhead, Will, and North, I960; Cullis, Muirhead, Perutz, Rossman, and North, 1962) has revealed the over-all arrangement of the molecules, and the model these workers have built on the basis of their x-ray crystallographic work is shown in Fig. I and 2. In over-all shape, the molecule resembles a spheroid $64 \AA \times 55 \AA \times 50 \AA$. It can be seen that each molecule consists of four polypeptide chains and that a haem group is

Received November 13, 1964.

* Senior Beit Memorial Fellow. attached to each chain. Each molecule consists $\overrightarrow{\mathscr{O}}$ of two pairs of identical chains, called $\alpha$ - and $\mathrm{c}$ $\beta$-chains, so that its structure can be written $\alpha_{2} \beta_{2}$. In Fig. I and 2, the two $\alpha$-chains are in white, while the two $\beta$-chains are in black. The internal arrangement of the two types of chain is very similar, the main difference being that $\stackrel{\square}{\perp}$ the $\beta$-chain is slightly longer, and this is confirmed $\underset{F}{\Rightarrow}$ by the amino acid sequence studies described later. The model further shows that there is relatively little contact between pairs of like chains, whereas there is striking complementarity between adjacent surfaces of $\alpha$ - and $\beta$-chains. The haem groups are not particularly close to one another, and their $\frac{0}{\circ}$ arrangement offers no clue to the influence they 3 exert on each other in the oxygenation reaction. Recently, however, Muirhead and Perutz (1963) and Perutz (1964) have found that the arrangement $O$ of the subunits alters during oxygenation. It appears that the $\beta$-chains move closer together on oxygenation, decreasing the distance between their haem groups by $7 \AA$.

The haem groups lie in four separate pockets $N$ on the surface of the molecule, each pocket being N formed by the folds of one of the four polypeptide $\sigma$ chains. Each haem group is attached to its polypeptide chain by a co-ordinate linkage from the iron of the haem group to a specific histidine $\stackrel{\infty}{\rightarrow}$ residue at position 87 in the amino acid sequence in the $\alpha$-chain and at position 92 in the $\beta$-chain. Another histidine occurs in each polypeptide $\mathbb{\Phi}$ chain on the opposite side of the haem group $\mathbb{D}$ $(58 \alpha$ and $63 \beta)$ and is linked to the iron of the haem 
group through either an oxygen molecule in oxyhaemoglobin or a water molecule in reduced haemoglobin.

\section{Normal Human Haemoglobins}

There are several normal human haemoglobins at different stages of human development: adult, foetal, and embryonic.

\section{Haemoglobins Found in Adult Life.}

HAEMogLobin A. As explained above, $\mathrm{Hb}$-A consists of two $\alpha^{\mathrm{A}}$-chains joined to two $\beta^{A}$-chains. The formula for $\mathrm{Hb}-\mathrm{A}$ can thus be written $\alpha_{2}^{\mathbf{A}} \beta_{2}^{\mathbf{A}}$ (superscripts, as, for example, $\alpha^{\mathrm{A}}$, designate the source of each chain, while subscripts denote the number of each type of chain present (Schroeder, 1959)). The amino acid sequences of each chain are given in Fig. 3. When the sequences of the two chains are compared, it is found that the $\beta$-chain has 5 amino acids more than the $\alpha$-chain and, although many parts of the amino acid sequence are the same, there are approximately 84 differences between the two chains. The molecular weight of the haemoglobin molecule calculated from the above structure is 64,500 .

HaEmoglobin $A_{2}$. Hb- $A_{2}$ occurs in all normal haemolysates after the postnatal period and amounts to I.5$3 \%$ of total haemoglobin (Kunkel, Ceppellini, Müller-Eberhard, and Wolf, 1957). It is distinguished from $\mathrm{Hb}-\mathrm{A}$ by its slower electrophoretic migration towards the anode and can be separated by all the conventional systems. It can also be separated by chromatography on carboxymethylcellulose (CMC) (Huisman, Martis, and Dozy, I958), diethylaminoethylcellulose (DEAE) (Huisman and Dozy, 1962) and Amberlite IRC 50 (Schnek and Schroeder, 196I). A convenient two-step preparative method has also been described (Huehns and Shooter, 196Ib). In its alkali denaturation rate and absorption spectrum, $\mathrm{Hb}-\mathrm{A}_{2}$ resembles Hb-A.

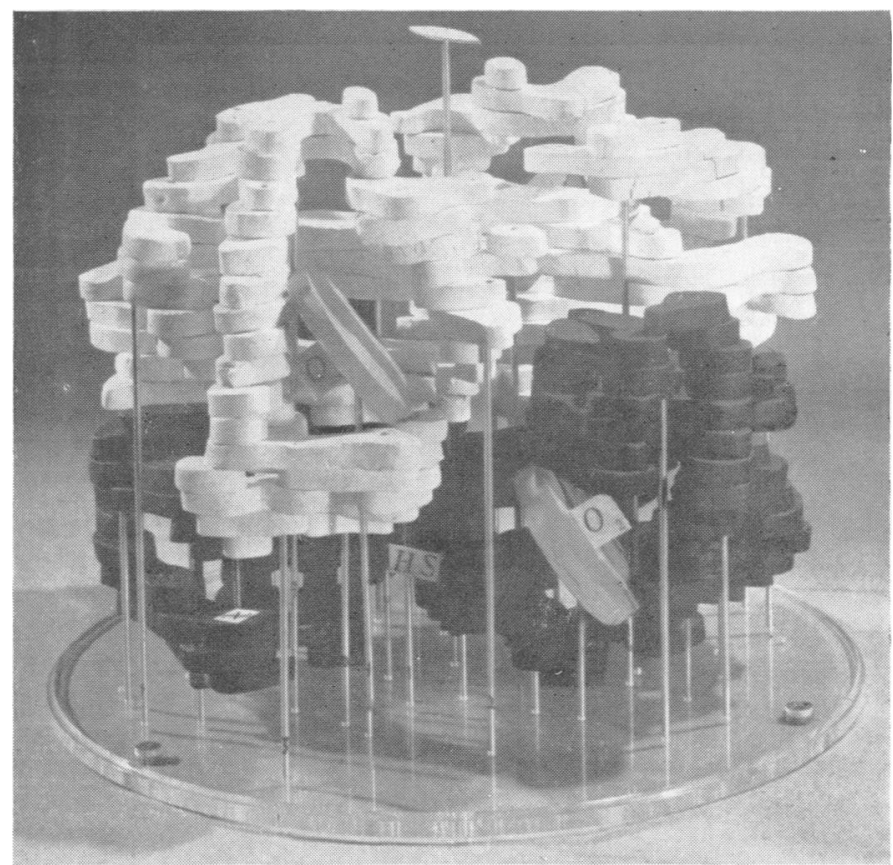

FIg. I. The structure of horse haemoglobin at $5.5 \AA$ showing the arrangement of the four subunits. The white chains are $\alpha$-chains and the black $\beta$-chains (from Perutz et al. (1960) with permission).

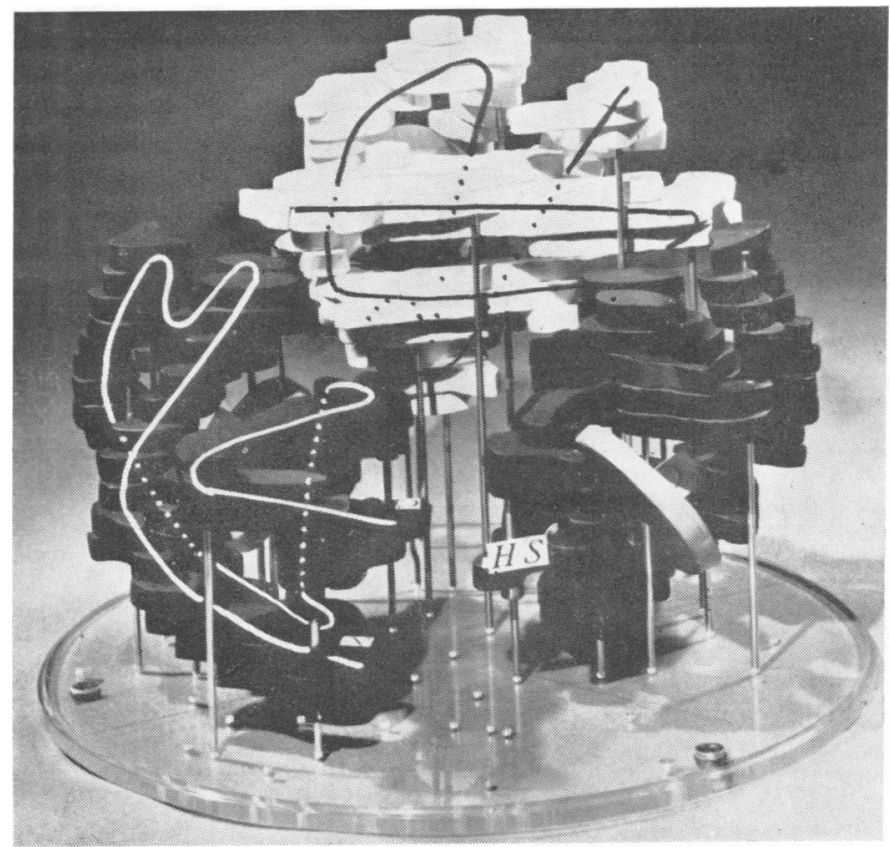

Fig. 2. A similar model to that in Fig. I with one of the white $\alpha$-chains omitted to show the close contact between white $\alpha$ - and black $\beta$-chain subunits (from Perutz et al. (1960) with permission). 


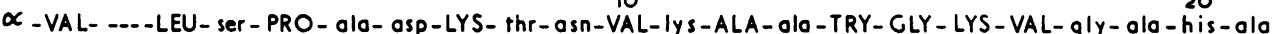

B-VAL- his - LEU - thr - PRO- glu- glu-LYS- ser- ala-VAL-thr-ALA- leu-TRY- GLY - LYS-VAL- osn-val---- 10 - 20

í $\alpha$-gly-GLU -tyr-GLY - olo-GLU-ALA-LEU - glu-ARG-met-phe-leu-ser-phe-PRO-thr-THR-Iys-th 30

$\because$ - $\alpha$ - pro-his-PHE - ... - ASP-LEU-SER-his-gly-ser-ALA- ... - ............. - 60 $\beta$ - glu-ser-PHE - gly - ASP-LEU-SER-thr-pro-osp-ALA-vol-met-gly-asn-pro-Iys-VAL-LYS-ala-HIS-GLY-LYS

V- $\alpha$-LYS-VAL-ola-osp-ALA-leu-thr-asn-olo-vol-ALA-HIS-val-ASP-osp-met-pro-asn-ola-leu-ser-ala- LEU B-LYS-VAL-leu-gly-ALA-phe-ser-asp-gly-leu-ALA-HIS-leu-ASP-osn-leu-lys-gly-thr-phe-ala-thr-LEU

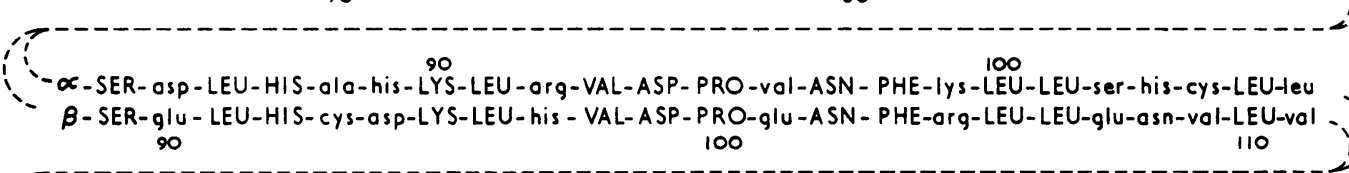

' $\alpha$ - vol-thr-LEU-ALA-olo-HIS-leu-pro-olo-GLU-PHE-THR-PRO-olo-VAL-his-ALA-ser-leU-osp-LYS-phe-leu

$\alpha$ - vol-thr - LEU-ALA-olo-HIS-leu-pro-olo-CLU-PHE-THR-PRO-alo-VAL-his-ALA-ser-leU-osp-LYS-phe-leU
$\beta$ - cys-val-LEU-ALA-his-HIS-phe-gly-lys-GLU-PHE-THR-PRO-pro-VAL-gln-ALA-olo-tyr-gln-LYS-vol-val 120 130

\footnotetext{
$130 \quad$ I40 C-terminus

A LA-ser-VAL-ser-thr-vol-LEU-thr-ser-LYS-TYR-org

B-ALA-gly-VAL-olo-osn-ola-LEU-ola-his- LYS-TYR-his

140
}

Fig. 3. The amino acid sequence of the $\alpha^{A_{-}}$and $\beta^{A}$-chains (compiled by Schroeder ( 1963 ) from the data of Braunitzer, GehringMüller, Hilschmann, Hilse, Hobom, Rudloff, and WittmanLiebold (196I); Konigsberg and Hill (1962); Schroeder, Shelton, Shelton, and Cormick (1962)). The amino acids that are identical in the two chains are indicated by capital letters.

\section{TABLE I}

AMINO ACID DIFFERENCES OF $\delta$-CHAIN OF Hb-A COMPARED WITH $\beta^{A}$-CHAINS (Ingram and Stretton, 1962a, $b$ Hill and Kraus I963; Jones, 1964)

\begin{tabular}{c|l|l}
\hline $\begin{array}{c}\text { Position in } \\
\text { Amino Acid Sequence }\end{array}$ & $\begin{array}{c}\text { Residue in } \\
\beta^{\mathbf{A}} \text {-chain }\end{array}$ & $\begin{array}{l}\text { Residue in } \\
\delta^{\mathbf{A}_{2} \text {-chain }}\end{array}$ \\
\cline { 1 - 3 } 9 & Ser & Thr \\
12 & Thr & AspNH \\
22 & Glu & Ala \\
50 & Thr & Ser \\
$86 ?$ & Ala & Ser \\
$87 ?$ & Thr & GluNH \\
116 & His & Arg \\
117 & His & AspNH \\
125 (or 124) & Pro & GluNH \\
126 & Val & Met \\
\hline
\end{tabular}

$\mathrm{Hb}-\mathrm{A}_{2}$, like other haemoglobins, consists of four polypeptide chains, two of which are identical to the $\alpha^{\mathrm{A}}$-chains (Muller and Jonxis, I960; Huehns and Shooter, I96ra, b; Ingram and Stretton, I96I; I962a, b). The other two are very similar to the $\beta$-chains but differ by ten amino acid substitutions (Table I) (Ingram and Stretton, 196I; 1962a, b; Hill and Kraus, 1963; Jones, 1964). These non- $\alpha$-chains have been called $\delta$-chains, and the structure of $\mathrm{Hb}-\mathrm{A}_{2}$ is therefore $\alpha_{2}^{\mathbf{A}_{2}} \delta_{2}^{\mathbf{A}_{2}}$.

Other Minor AdUlt Haemoglobins. Several other minor haemoglobin components are found in adult haemolysates. $\mathrm{Hb}-\mathrm{A}_{3}$, which forms approximately 10\% of total haemoglobin (Kunkel and Wallenius, 1955), appears to be derived from $\mathrm{Hb}-\mathrm{A}$ during in vivo ageing of the red cells (Kunkel and Bearn, 1957; Meyering, Israels, Sebens, and Huisman, 1960). Hybridization of $\mathrm{Hb}-\mathrm{A}_{3}$ shows that it differs from $\mathrm{Hb}-\mathrm{A}$ in the $\beta$-chains (Rosa and Labie, 1962). More recent work indicates 
that $\mathrm{Hb}-\mathrm{A}_{3}$ is a mixture of haemoglobins (Schnek and Schroeder, 196I; Huisman and Meyering, 1960). Schnek and Schroeder (I96I) have detected several minor components in normal haemolysates by chromatography on IRC 50 and have called

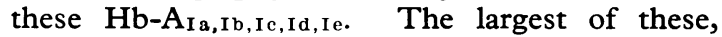
$\mathrm{Hb}-\mathrm{A}_{\mathrm{Ic}}$, amounting to approximately $5 \%$ of total haemoglobin, has the structure $\alpha_{2}^{\mathbf{A}} \beta^{\mathrm{A}} \beta \mathrm{x}$, the $\beta^{\mathrm{x}}$-chain differing from the $\beta^{\mathrm{A}}$-chain by the substitution of the terminal $\mathrm{NH}_{2}$ group (Holmquist and Schroeder, 1964). It has also been suggested that part of the $\mathrm{Hb}-\mathrm{A}_{3}$ fraction is composed of a complex of oxidized glutathione (GSSG) with Hb-A (Muller, 196I; Huisman and Dozy, 1962). However, it is not known whether this complex is present in vivo. Hybridization experiments show that the GSSG is attached to the $\beta$-chains.

A small quantity of foetal haemoglobin is also present in adult red cells (Chernoff, 1953b), but this does not amount to more than $0.4 \%$ (Beaven, Ellis, and White, I960b).

\section{Haemoglobins in Foetal Life.}

Foetal Haemoglobin. Hb-F is the major pigment found in the red cells during foetal life and differs in several respects from $\mathrm{Hb}-\mathrm{A}$. It was first detected in 1866 by Körber, who noticed that this pigment was denatured more slowly by alkali than that found in adult red cells.

Foetal haemoglobin, like Hb-A, consists of four polypeptide chains. Two of these are identical to the $\alpha^{\mathrm{A}}$-chains (Schroeder and Matsuda, 1958; Hunt, 1959; Schroeder, 1963), while the other two chains have the same number of amino acids as the $\beta$-chains but differ from them in 39 amino acid residues and are called $\gamma$-chains. The structure of $\mathrm{Hb}-\mathrm{F}$ is thus $\alpha_{2}^{\mathrm{A}} \gamma_{2}^{\mathrm{F}}$. The amino acid sequence of the $\gamma$-chains is given in Fig. 4 .

$\mathrm{Hb}-\mathrm{F}$ differs from $\mathrm{Hb}-\mathrm{A}$ by its greater resistance to alkali denaturation (Körber, I866), and this property is used to measure the amount of $\mathrm{Hb}-\mathrm{F}$ in various haemolysates (Singer, Chernoff, and Singer, I95I; Beaven, Ellis and White, I960a; Betke, Marti, and Schlicht, 1959). The haem absorption spectrum of $\mathrm{Hb}-\mathrm{F}$ is identical to that of $\mathrm{Hb}-\mathrm{A}$. However, there is a distinct difference in the protein absorption at about $290 \mathrm{~m} \mu$. In $\mathrm{Hb}-\mathrm{F}$ the tryptophan fine structure band is resolved at 2,896 $\AA$, while in $\mathrm{Hb}-\mathrm{A}$ it is unresolved at 2,910 $\AA$ (Jope, 1949; Beaven et al., 1960a), the difference arising from the altered tryptophan/tyrosine ratios of the two haemoglobins.

$\mathrm{Hb}-\mathrm{F}$ can be separated from Hb-A by electrophoresis either in agar gel, using a sodium citrate

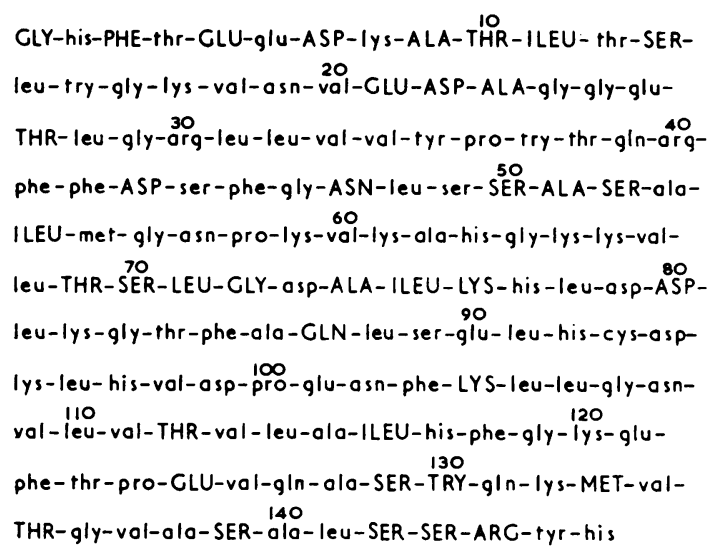

FIG. 4. The amino acid sequence of the $\gamma^{F}$ chain. The residues that differ from those in the $\beta^{\mathrm{A}}$ chain have been capitalized (Schroeder, 1963).

buffer at $p \mathrm{H} 6 \cdot 2$ (Robinson, Robson, Harrison, and Zuelzer, 1957), or in starch gel with a trisE.D.T.A.-borate buffer at $p \mathrm{H} 8.6$ (O. Smithies, unpublished). In other electrophoretic systems, consistent separation of $\mathrm{Hb}-\mathrm{A}$ and $\mathrm{Hb}-\mathrm{F}$ is difficult to achieve. Chromatographically, $\mathrm{Hb}-\mathrm{F}$ is most conveniently separated on IRC 50 resin, using a sodium phosphate buffer at approximately $\mathrm{pH} 7 \cdot 0$ (Allen, Schroeder, and Balog, 1958). This method is useful for the preparation of pure $\mathrm{Hb}-\mathrm{F}$.

Minor Foetal Haemoglobins. Several minor haemoglobins are present in foetal blood. The largest of these is $\mathrm{Hb}-\mathrm{F}_{\mathrm{I}}$ (Allen et al., 1958), which amounts to approximately $10 \%$ of total haemoglobin. This has the structure $\alpha_{2}^{A} \gamma^{F} \gamma^{X}$, the $\gamma^{\mathrm{X}}$-chain differing from the $\gamma^{\mathrm{F}}$-chain by the substitution of the terminal $\mathrm{NH}_{2}$ group with an acetyl group (Schroeder, Cua, Matsuda, and Fenninger, 1962). A small amount of $\mathrm{Hb}-\gamma_{4}$ is also detected by starch gel electrophoresis (Karaklis and Fessas, 1963) and amounts to approximately $0.3 \%$ of total haemoglobin in normal cord bloods (Huehns, Dance, Beaven, Hecht, and Motulsky, I964b).

After birth, the proportion of $\mathrm{Hb}-\mathrm{F}$ found in haemolysates rapidly falls (Fig. 5), only traces being present after the first year of life (White and Beaven, 1959).

Embryonic Haemoglobins. The possibility of the existence of a human embryonic haemoglobin was first suggested by Drescher and Künzer (I954). Recently, it has been shown by starch gel 


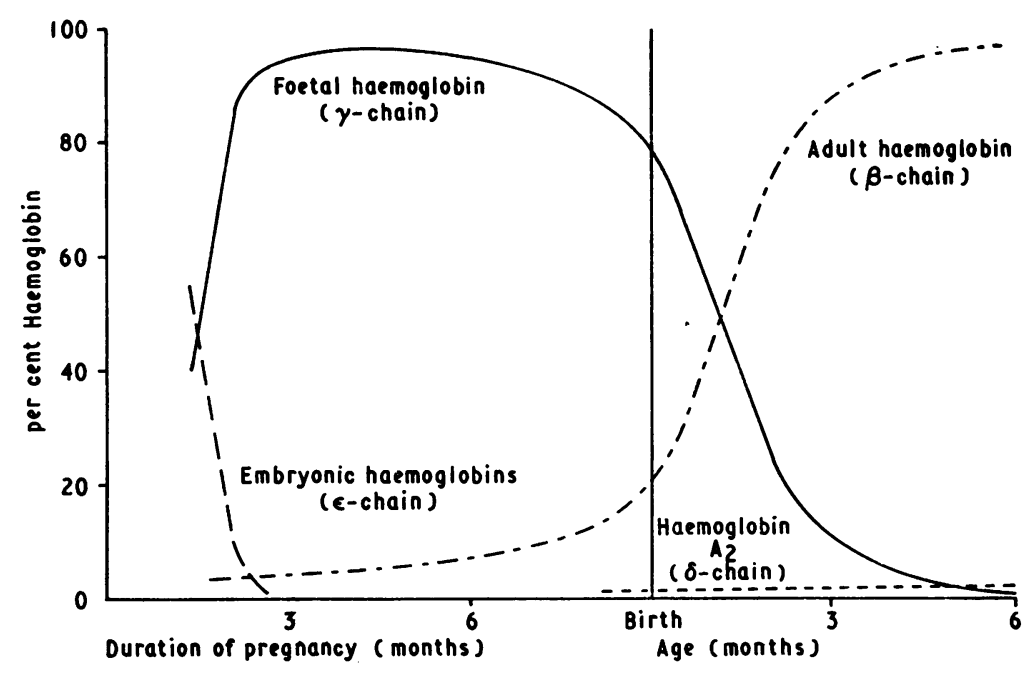

FIG. 5. The developmental changes in human haemoglobins.

electrophoresis (Fig. 6) that there are two embryonic haemoglobins, $\mathrm{Hb}$-Gower $\mathrm{I}$ and $\mathrm{Hb}-$ Gower 2 (Huehns, Flynn, Butler, and Beaven, 196ra; Huehns, Dance, Beaven, Keil, Hecht, and Motulsky, r964a).

$\mathrm{Hb}$-Gower 2 consists of four polypeptide chains. Again, two $\alpha^{\mathrm{A}}$-chains are present, while the other two chains differ from the $\beta$-, $\gamma$-, and $\delta$-chains by more than one amino acid substitution and have been called $\varepsilon$-chains (Huehns et al., 1964a; Huehns, Hecht, Keil, and Motulsky, 1964c).
Hb-Gower 2 has an alkali denaturation rate $\ddot{\mathscr{C}}$

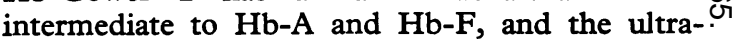
violet absorption spectrum resembles that of $\mathrm{Hb}-\mathrm{F}$ rather than that of $\mathrm{Hb}-\mathrm{A}$. It has not yet been possible to study $\mathrm{Hb}$-Gower I in detail, but it has been suggested that it consists solely of $\varepsilon$-chains.

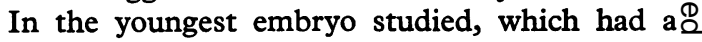
crown-rump (C.R.) measurement of $25 \mathrm{~mm}$., $\vec{\circ}$ the haemolysate contained mainly $\mathrm{Hb}-\mathrm{F}, 24 \% 3$ Hb-Gower I, $13 \% \mathrm{Hb}$-Gower 2, approximately? $5 \% \mathrm{Hb}-\mathrm{A}$, and $\mathrm{I} \% \mathrm{Hb}-\gamma_{4}$. The amount of these

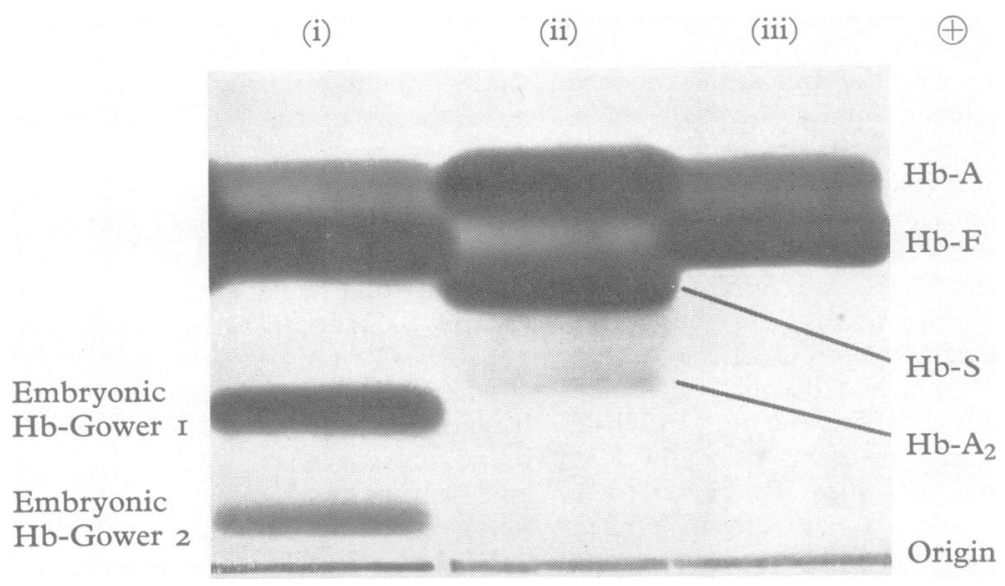

FIG. 6. Starch gel electrophoresis in a tris-E.D.T.A.-borate buffer pH 8.6: (i) haemolysate from $3.5 \mathrm{~cm}$. (crown rump) human embryo; (ii) Hb-A + S marker; (iii) normal cord blood. 
embryonic haemoglobins falls rapidly as development proceeds and they are not normally found after the $100 \mathrm{~mm}$. C.R. stage of development (Fig. 5).

\section{The Abnormal Haemoglobins}

The discovery by Pauling, Itano, Singer, and Wells (1949) that the haemoglobin in sickle cell disease differed from normal haemoglobin in its rate of migration on electrophoresis showed for the first time that an abnormal protein molecule could be the primary cause of a severe disease. Since then, a large number of haemoglobins have been discovered. Some of these have been found through the study of patients with various haematological disorders, but the majority have been discovered during surveys carried out in various parts of the world. These have been distinguished from each other by differences in behaviour on electrophoresis. Some of the abnormal haemo- globins with similar electrophoretic mobilities have been further differentiated by other methods, for example, by chromatography on IRC 50 (Huisman and Prins, 1955). The properties of the various abnormal haemoglobins have been reviewed by Beaven and Gratzer (I959), Lehmann (1960), and Lehmann and Ager (1960). The relative electrophoretic mobilities of various abnormal haemoglobins are shown in Figs. 7 and 8. More recently, the structure of a number of abnormal haemoglobins has been determined (as outlined in the next section) and on this basis the existence of definitive species has been firmly established (Table II).

The next discovery in the study of the abnormal haemoglobins was made by Ingram (1956, 1958, 1959) and Hunt and Ingram (1958), who showed that in sickle cell haemoglobin, or Hb-S, only the $\beta$-chains were abnormal, while the $\alpha$-chains were identical to those found in $\mathrm{Hb}-\mathrm{A}$. The structure of $\mathrm{Hb}-\mathrm{S}$ could then be written as $\alpha_{2}^{\mathrm{A}} \beta_{2}^{\mathrm{S}}$. Ingram also showed that in each $\beta^{\text {s }}$-chain only one amino

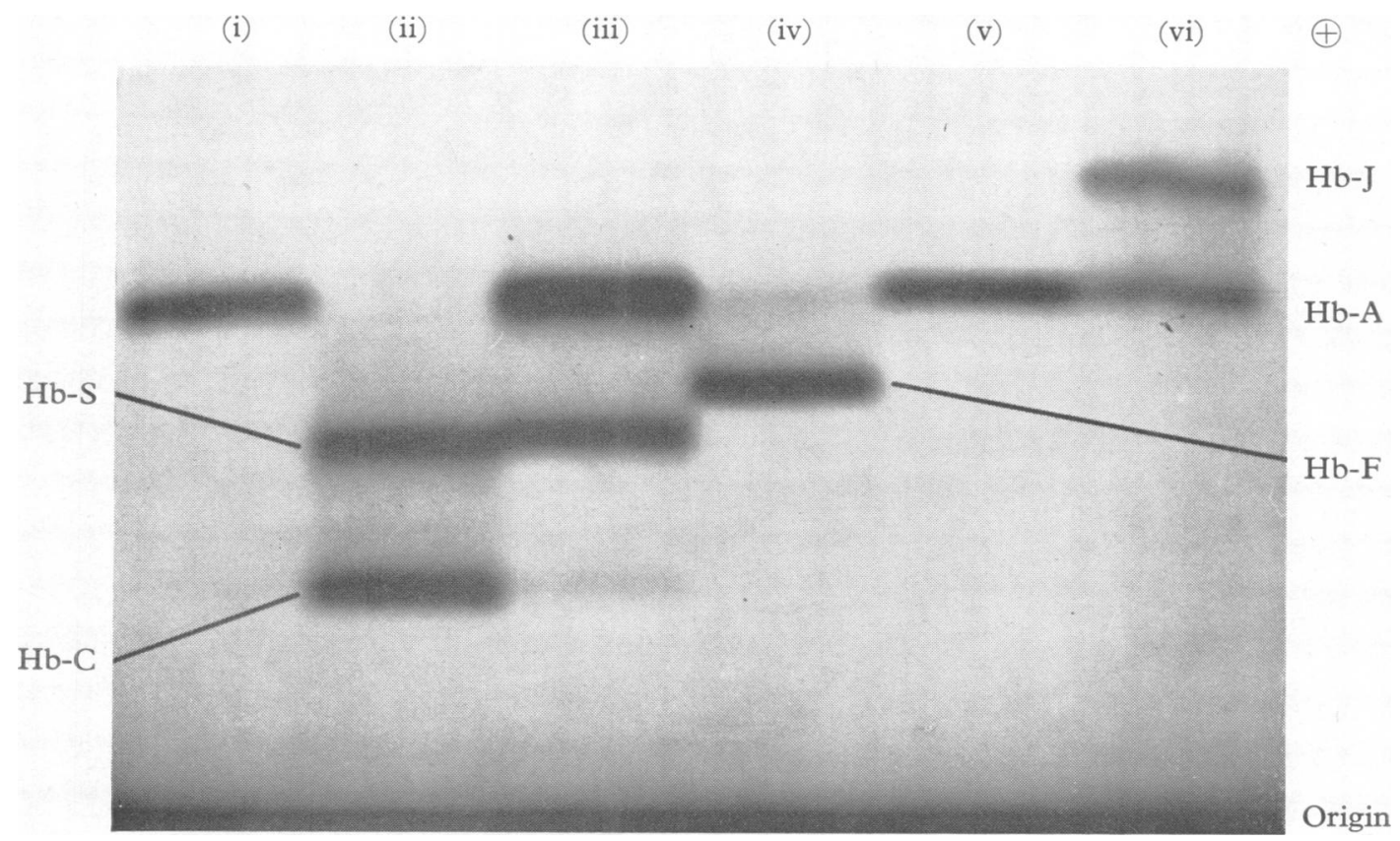

FIG. 7. Starch gel electrophoresis in a tris-E.D.T.A.-borate buffer pH 8.6: (i) normal adult haemolysate; (ii) $\mathrm{Hb}-\mathrm{S}+\mathrm{C}$; (iii) $\mathrm{Hb}-\mathrm{A}+\mathrm{S}$; (iv) normal cord blood; (v) normal adult; and (vi) $\mathrm{Hb}-\mathrm{A}+\mathrm{J}$. The slight difference in electrophoretic migration between $\mathrm{Hb}-\mathrm{S}$ in samples (ii) and (iii) is due to the effect of the other haemoglobins present in each haemolysate, illustrating one of the difficulties encountered in interpreting slight differences in electrophoretic mobility (from Huehns and Shooter, 1964a; with kind permission of Blackwell Scientific Publications Ltd.). 


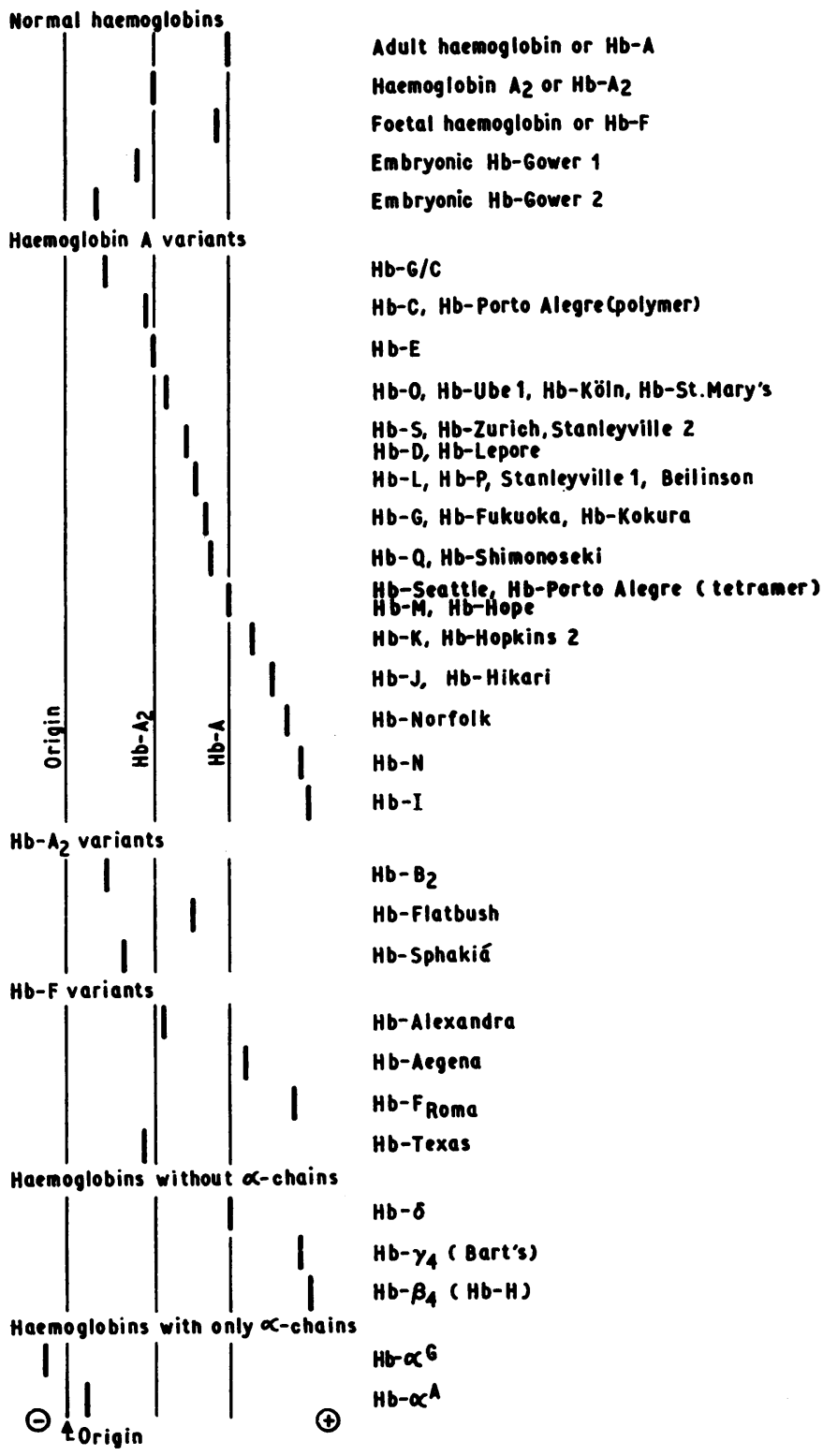

acid out of 146 was different, the glutamyl residue which is found in the $\beta^{A}$-chain at position 6 from the $N$-terminal end being replaced by a valyl residue. A shorthand for this structure gives the number of the amino acid residue substituted and the new amino acid as a superscript to the affected chains: Hb-S would then be $\alpha_{2}^{A} \beta_{2}^{6 V a l}$ (Gerald and Ingram, 196I).

A similar situation has now been found for almost all other abnormal haemoglobins so far analysed (except those mentioned later), one amino acid residue being substituted in either the $\beta$ - or the 
$\alpha$-chains. Thus, the abnormal haemoglobins fall into two main groups:

(i) those with abnormal $\alpha$-chains

(ii) those with abnormal $\beta$-chains, and these are listed in Table II.

It can be seen from Table II that several types previously thought to be identical are now known to differ; for example, there are at least three structurally different haemoglobins called Hb-D (Benzer, Ingram, and Lehmann, 1958). On the other hand, 5 independently described species of $\mathrm{Hb}-\mathrm{G}_{\alpha}$ or $\mathrm{Hb}-\mathrm{D}_{\alpha}$ have been shown to be chemically identical to $\mathrm{Hb}-\mathrm{G}_{\mathrm{Phil}}$ adelphia. Three types of Hb-J are known: Hb-J Baltimore, $\alpha_{2}^{A} \beta_{2}^{16 A s p}$ (Baglioni and Weatherall, 1963), Hb-J Rambam, $\alpha_{2}^{A} \beta_{2}^{\text {TpIX }}$ (Salomon, Tatarski, Dance, Huehns, and Shooter, 1964), and Hb-Joxford, $\alpha_{2}^{\mathrm{J}} \beta_{2}^{\mathrm{A}}$ (Beale and Lehmann, 1964). However, the species Hb-J Trinidad and Hb-Jirel and (Gammack, Huehns, Lehmann, and Shooter, I96I) are now known to be identical to $\mathrm{Hb}-\mathrm{J}_{\text {Baltimore }}(\mathrm{N}$. Dance, E. R. Huehns, and E. M. Shooter, unpublished).

Fig. 9 illustrates the distribution of the known amino acid substitutions along the $\alpha$ - and $\beta$-chains and indicates that substitutions can occur in most parts of both chains. However, some regions of the chains appear to have more than their fair share of the known anomalies. Several reasons for this can be advanced, but it is perhaps a reflection of the ability of any substitution to cause a change in electrophoretic mobility which would lead to its detection on routine electrophoresis. Thus, substitutions in parts of the polypeptide chain that are buried in the molecule are less likely to be detected than those that are on the surface. In other cases, the presence of disease such as methaemoglobinaemia or haemolytic anaemia has led to a number of very detailed studies, revealing the presence of several different abnormal haemoglobins with amino acid substitutions near the haem group.

It will also be seen from Fig. 9 that in some positions more than one substitution has been detected, for example, at position 6 in the $\beta$-chains. In $\mathrm{Hb}-\mathrm{S}$, valine is found at this site, while in $\mathrm{Hb}-\mathrm{C}$, lysine is present. Occasionally, substitutions at corresponding places in the $\alpha$ - and $\beta$-chains (allowing for the extra amino acids found in the $\beta$-chain) lead to haemoglobins which in their properties are almost indistinguishable. In this class are $\mathrm{Hb}-\mathrm{J}_{\mathrm{Baltimore}}\left(\alpha_{2}^{\mathrm{A}} \beta_{2}^{16 \mathrm{Asp}}\right)$ and $\mathrm{Hb}-\mathrm{J}_{\text {oxford }}$ $\left(\alpha_{2}^{15 A s p} \beta_{2}^{A}\right), \mathrm{Hb}-\mathrm{O}_{\mathrm{Arabia}}\left(\alpha_{2}^{\mathrm{A}} \beta_{2}^{121 \mathrm{ILS}^{2}}\right)$ and Hb-O Indonesia $\left(\alpha_{2}^{116 L 8 \mathrm{~s}} \beta_{2}^{A}\right)$. The significance, if any, of all these findings in relation to the natural occurrence of point mutations in man is not yet clear.
Haemoglobin $A_{2}$ Variants. $H b-A_{2}$ has the structure $\alpha_{2}^{\Lambda} \delta_{2}^{\Lambda}$, and both $\alpha$-chain and $\delta$-chain variants have been described.

$H b-B_{2}$, which was the first $\mathrm{Hb}-\mathrm{A}_{2}$ variant discovered (Ceppellini, r959; Huisman and Meyering, 1960), occurs in approximately $1 \%$ of American Negroes. On electrophoresis it migrates more slowly than $\mathrm{Hb}-\mathrm{A}_{2}$ (Fig. 8). Chemical studies indicate that it has abnormal $\delta$-chains (Horton, Payne, Bridges, and Huisman, 196I) and that the amino acid substitution is glycine $\rightarrow$ arginine at position I6 (A. O. W. Stretton, cited by Baglioni, r963a).

$\mathrm{Hb}$-Flatbush is another $\mathrm{Hb}-\mathrm{A}_{2}$ variant with abnormal $\delta$-chains (Ranney, Jacobs, Bradley, and Cordova, 1963). This haemoglobin migrates on electrophoresis with $\mathrm{Hb}-\mathrm{S}$ (Fig. 9).

$\mathrm{Hb}$-Sphakiá is probably another variant of Hb- $\mathrm{A}_{2}$ with abnormal $\delta$-chains (C. Krimbas, N. A. Barnicot, and R. B. MacConnell, unpublished). It was found in a single family in Greece. On electrophoresis it migrates between $\mathrm{Hb}-\mathrm{A}_{2}$ and $\mathrm{Hb}-\mathrm{B}_{2}$.

Haemoglobin $F$ Variants. Hb-F $F_{\text {Roma }}$ was found in an Italian neonate (Silvestroni and Bianco, 1963). These workers showed that this was a $\gamma$-chain variant of $\mathrm{Hb}-\mathrm{F}$ by hybridization, spectral and alkali denaturation studies. On electrophoresis, $\mathrm{Hb}-\mathrm{F}_{\mathrm{Rom} \text { a }}$ migrates more rapidly than either $\mathrm{Hb}-\mathrm{F}$ or $\mathrm{Hb}-\mathrm{A}$ towards the anode. Hb-Texas (Schneider, Arat, and Haggard, I964a) is another $\gamma$-chain variant. On electrophoresis, this haemoglobin migrates slightly slower (cathodally) than $\mathrm{Hb}-\mathrm{C}$. Chemical studies indicate that a glutamyl residue is replaced by a lysyl residue in tryptic peptide $\gamma \mathrm{TpI}$ either at position 5 or position 6 (R. Schneider and R. T. Jones, personal communication). This substitution is the same as that found in $\mathrm{Hb}-\mathrm{C} \quad(\beta 6 \mathrm{Glu} \rightarrow \mathrm{Lys})$ or Hb-C Geor getown $\left(\beta_{7} \mathrm{Glu} \rightarrow\right.$ Lys) and, similarly, occurs near the $\mathrm{N}$-terminal of the polypeptide chain involved. Other $\gamma$-chain variants of $\mathrm{Hb}-\mathrm{F}$ may be Hb-Alexandra (Fessas, Mastrokalos, and Fostiropoulos, 1959; Vella, Ager, and Lehmann, 1959) and Hb-Aegena (Fessas, Karaklis, and Gnafakis, 196I). On electrophoresis Hb-Alexandra migrates with $\mathrm{Hb}-\mathrm{O}, \mathrm{Hb}-A$ egena slightly faster than $\mathrm{Hb}-\mathrm{A}$ (Fig. 8).

$\alpha$-chain variants of $\mathrm{Hb}-\mathrm{A}_{2}$ and $\mathrm{Hb}-\mathrm{F}$ are found in all subjects who synthesize abnormal $\alpha$-chains; thus, for example, $\mathrm{Hb}-\mathrm{G}_{\alpha}\left(\alpha_{2}^{\mathrm{a}} \beta_{2}^{A}\right)$ is accompanied by its own $\mathrm{Hb}-\mathrm{A}_{2}$ variant, called $\mathrm{Hb}-\mathrm{G}_{2}\left(\alpha_{2}^{\mathrm{G}} \delta_{2}\right)$ (Huehns and Shooter, I96ra) and during foetal life the corresponding $\alpha$-chain variant of $\mathrm{Hb}-\mathrm{F}$, 
TABLE II

Chrmical. Differences between Abnormal Haemoglobins and Haemoglobin A

\begin{tabular}{|c|c|c|c|c|}
\hline Abnormal Haemoglobin & $\begin{array}{l}\text { Amino Acid } \\
\text { Residue Position }\end{array}$ & $\begin{array}{r}\text { Residue } \\
\text { in } \mathbf{H b}-\mathbf{A}\end{array}$ & $\begin{array}{l}\text { Residue in } \\
\text { Abnormal } \\
\text { Haemoglobin }\end{array}$ & Reference \\
\hline$\alpha$-CHAIN ABNORMALITIES & & & & \\
\hline $\begin{aligned} & \text { GPhiladelphia } \\
= & G_{\text {Bristol }} \\
= & G_{\text {Azuokoli }} \\
= & D_{\text {st. Louls }} \\
= & \text { D Washington }\end{aligned}$ & 68 & Asg & Lys & $\begin{array}{l}\text { Baglioni and Ingram, r961 } \\
\text { Dance, Huehns, and Shooter, } 1964 \\
\text { Weatherall, Sigler, and Baglioni, } 1962\end{array}$ \\
\hline $\mathbf{I}$ & 16 & Lys & Asp & Murayama, I962a \\
\hline JMedellin & 22 & Gly & Asp & Gottlieb, Restrepa, and Itano, 1964 \\
\hline MBoston & 58 & His & Tyr & Gerald and Efron, $196 \mathrm{I}$ \\
\hline $\begin{aligned} & \text { MIwate } \\
= & \text { M Kankakee }_{\text {Kan }}\end{aligned}$ & 87 & His & Tyr & $\begin{array}{l}\text { Miyaji et al., 1963a } \\
\text { Jones et al., } 1964\end{array}$ \\
\hline OIndonesia & 116 & Glu & Lys & Baglioni and Lehmann, 1962 \\
\hline Mexico & 54 & Glm & Glu & Jones, Koler, and Lisker, 1963 \\
\hline Norfolk & 57 & Gly & Asp & Baglioni, I962c \\
\hline Joxford & 15 & Gly & Asp & Beale and Lehmann, I964 \\
\hline LFerrara & 47 & Asp & Gly & Baglioni (personal communication) \\
\hline $\begin{aligned} & \text { GHonolulu }_{\text {Hingapore }} \\
= & \mathbf{G}_{\text {Sing Kong }}\end{aligned}$ & 30 & Glu & Gln & Swenson, Hill, Lehmann, and Jim, 1962 \\
\hline Shimonoseki & 54 & Glm & Arg & $\begin{array}{l}\text { Hanada and Rucknagel, r963; Miyaji, Iuchi. Takeda, } \\
\text { and Shibata, 1963b }\end{array}$ \\
\hline
\end{tabular}

$\mathbf{D}_{\boldsymbol{\alpha}}$

Q

Stanleyville II

Beilinson

Kokura (Umi)

In the following haemoglobins only the abnormal tryptic peptide has been determined

$$
\begin{gathered}
\alpha \text { TpIV } \\
\alpha \text { TpIX } \\
\text { 'core' } \\
\alpha \text { TpVI } \\
\alpha \text { TpVI }
\end{gathered}
$$

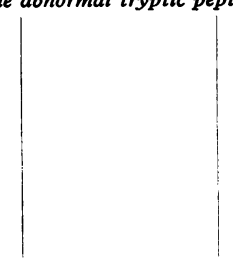

In the following haemoglobins only the abnormal polypeptide chains have been determined

\section{Gibadan \\ $\mathbf{K}_{\alpha}$ \\ $\mathbf{N}_{\alpha}$ \\ Russ}

Hopkins 2

B-CHAIN ABNORMALITIES

S

C

CGeorgetown

DPunjab

- Denicago

= DCyicago

$=$ DLos Angeles

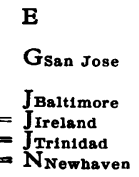

\section{Benzer et al., 1958}

Hill and Jones, cited by Schroeder, 1963

Hall-Craggs et al., 1964

De Vries, Joshua, Lehmann, Hill, and Fellow, 1963

Ohya, 1963

Gammack et al., 1960

Gammack et al., 196I

Silvestroni, Bianco, and Brancati, 1963

Huisman, 1962; Huisman and Sydenstricker, 1962?

Itano and Robinson, 1960

Ingram, 1959

Hunt and Ingram, 1960

Pierce et al., 1963

Baglioni, 1962a

Babin, Jones, and Schroeder, 1964

Hunt and Ingram, 1961

Hill, Swenson, and Schwartz, I960

Baglioni and Weatherall, 1963 Gammack et al., I960; Dance, Huehns, and Shooter, unpublished Chernoff and Perillie, r964 
TABLE II-continued

\begin{tabular}{|c|c|c|c|c|}
\hline Abnormal Haemoglobin & $\begin{array}{c}\text { Amino Acid } \\
\text { Residue Position }\end{array}$ & $\begin{array}{r}\text { Residue } \\
\text { in } \mathrm{Hb}-\mathrm{A}\end{array}$ & $\begin{array}{c}\text { Residue in } \\
\text { Abnormal } \\
\text { Haemogoblin }\end{array}$ & Reference \\
\hline \multicolumn{5}{|l|}{$\beta$-CHAIN ABNORMALITIES } \\
\hline $\begin{aligned} & \text { Msaskatoon } \\
= & M_{\text {Emory }} \\
= & M_{\text {Kurume }} \\
= & M_{\text {Radom }} \\
= & M_{\text {Chicago }}\end{aligned}$ & 63 & His & Tyr & $\begin{array}{l}\text { Gerald and Efron, 1961 } \\
\text { Shibata et al., r962a } \\
\text { Murawski et al., r964; Josephson et al., 1962; } \\
\text { P. Heller, personal communication }\end{array}$ \\
\hline$M_{\text {Milwaukee } 1}$ & 67 & Val & Glu & Gerald and Efron, I96I \\
\hline $\mathrm{O}_{\text {Arabla }}$ & 121 & Glu & Lys & Baglioni and Lehmann, 1962 \\
\hline Zurich & 63 & His & Arg & Muller and Kingma, I96I \\
\hline $\begin{aligned} & \mathrm{G}_{\text {Galveston }} \\
= & \mathrm{G}_{\text {Port Arthur }} \\
= & \mathrm{G}_{\text {Texas }}\end{aligned}$ & 43 & Glu & Ala & Bowman et al., 1964 \\
\hline Hikari & $6 I$ & Lys & Asg & Shibata, Miyaji, Iuchi, Ueda, and Takeda, I964 \\
\hline $\mathrm{G}_{\text {Accra }}$ & 79 & Asp & Asg & Lehmann, Beale, and Boi-Doku, 1964 \\
\hline $\mathrm{G}_{\text {Coushatta }}$ & $\begin{array}{l}22 \text { or } 26 \\
(\beta T \text { pIII })\end{array}$ & Glu & Ala & Schneider et al., 1964b \\
\hline Seattle & $\begin{array}{l}70 \text { or } 76 \\
(\beta \mathrm{TpIX})\end{array}$ & Ala & Glu & $\begin{array}{l}\text { Huehns, Hartmann, Hecht, and Motulsky, un- } \\
\text { published }\end{array}$ \\
\hline Rambam & $\begin{array}{l}69 \text { or } 74 \\
(3 \mathrm{TpIX})\end{array}$ & ? Gly & ? Asp & Salomon et al., 1964 \\
\hline Kenwood & I 43 & His & Glu or Asp & $\begin{array}{l}\text { Bayrakci, Josephson, Singer, Heller, and Coleman, } \\
\text { I } 964\end{array}$ \\
\hline \multicolumn{5}{|c|}{ In these haemoglobins only the abnormal tryptic peptide has been determined } \\
\hline Köln & ‘Core’ & & & Hutchinson et al., 1964 \\
\hline St. Mary's & ?'Core’ & & & Buchanan et al. (unpublished) \\
\hline R (Durham I) & ßTpI & & & Chernoff and Liu, I96I \\
\hline $\mathrm{D}_{\beta}$ & $\beta$ TpIII & & & Benzer et al., 1958 \\
\hline \multicolumn{5}{|c|}{ In these haemoglobins only the abnormal polypeptide chain has been determined } \\
\hline M Milwaukee: & & & & Gerald and Efron, $196 \mathbf{I}$ \\
\hline $\mathrm{K}_{\beta}$ & & & & $\begin{array}{l}\text { O'Gorman, Allsopp, Lehmann, and Sukumaran, } \\
\text { I } 963\end{array}$ \\
\hline $\mathrm{L}_{\beta}$ & & & & Gammack et al., 1961 \\
\hline $\mathbf{P}$ & & & & Silvestroni et al., 1963 \\
\hline
\end{tabular}

Hb-G F ( $\left.\alpha_{2}^{(\mathrm{i}} \gamma_{2}^{\mathrm{F}}\right)$, is found (Minnich, Cordonnier, Williams, and Moore, I962; see also later for further references).

\section{Haemoglobins with Unusual Structures.}

(a) Haemoglobins Without $\alpha$-Chains. Three haemoglobins without $\alpha$-chains have been desscribed, corresponding to the normal haemoglobins $A, F$, and $A_{2}$. All these haemoglobins migrate on electrophoresis more rapidly towards the anode than their $\alpha$-chain-containing parent species, and this difference in electrophoretic mobility is more marked near neutral $p \mathrm{H}$. $\mathrm{Hb}-\mathrm{H}$, the first of these to be discovered (Rigas, Koler, and
Osgood, 1955, 1956; Gouttas, Fessas, Tsevrenis, and Xefteri, I955), consists of four $\beta^{A}$-chains: Hb- $\beta_{4}^{\mathbf{A}}$ (Jones, Schroeder, Balog, and Vinograd, 1959). Fast foetal haemoglobin (Fessas and Papyspyrou, 1957) or Hb-Bart's (Ager and Lehmann, 1958) consists of four $\gamma^{\mathrm{F}}$-chains, $\mathrm{Hb}-\gamma_{4}^{\mathrm{F}}$ (Hunt and Lehmann, 1959; Kekwick and Lehmann, I960), and $\mathrm{Hb}-\delta$ consists solely of $\delta$-chains (Dance and Huehns, I962). Hb-Gower I may be a fourth haemoglobin without $\alpha$-chains, possibly consisting solely of $\varepsilon$-chains (Huehns et al., 1964a).

Huisman (1960) reports the occurrence of a haemoglobin consisting solely of $\beta^{\mathrm{s}}$-chains, $\mathrm{Hb}$ Augusta I, and another with only $\beta^{\mathrm{C}}$-chains, Hb-Augusta II. 

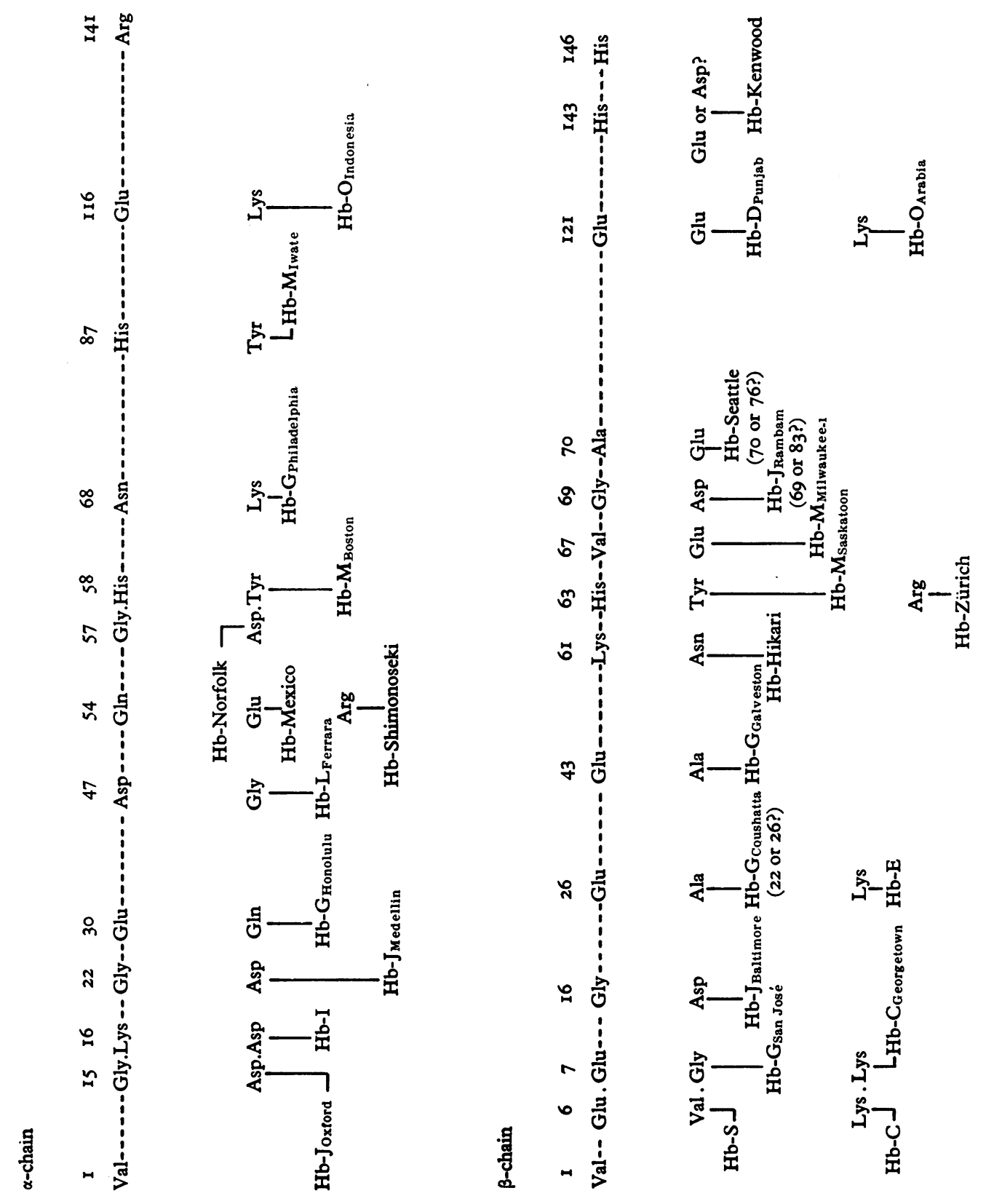
(b) Haemoglobins Consisting Solely of $\alpha$-CHAINS. Two haemoglobins of this type have been described: Hb- $\alpha^{A}$ (Huehns, Shooter, Dance, Beaven, and Shooter, I96Ib) and $\mathrm{Hb}-\alpha^{\mathrm{G}}$ (Huehns, Dance, Shooter, and Beaven, 1962b). These workers prepared the $\alpha$-chain haemoglobins by acid dissociation of $\mathrm{Hb}-\mathrm{A}$ or $\mathrm{Hb}-\mathrm{F}$. Since then, $\mathrm{Hb}-\alpha^{\mathbf{A}}$ has been detected by starch gel electrophoresis in small amounts in haemolysates from patients with $\beta$-thalassaemia major, particularly following splenectomy (Fessas and Loukopoulos, 1964), and from patients with unstable haemoglobins (Huehns and Shooter, unpublished). $\mathrm{Hb}-\alpha^{\mathrm{A}}$ cannot be detected in normal haemolysates prepared either from normal adult blood or cord blood by starch gel electrophoresis, though $0.02 \%$ of added $\mathrm{Hb}-\alpha^{\mathrm{A}}$ can be detected. Chernoff (1964) has isolated trace quantities $(0.05-0.3 \%)$ of $\mathrm{Hb}-\alpha^{\mathrm{A}}$ from normal haemolysates by DEAE column chromatography. However, the finding that when $\mathrm{Hb}-\mathrm{A}_{2}$ or $\mathrm{Hb}-\mathrm{F}$ are present more $\mathrm{Hb}-\alpha^{\mathrm{A}}$ can be detected on re-chromatography of the DEAE column eluate raises the possibility that DEAE promotes the dissociation of some haemoglobins.

(c) LePORE HAEMoglobin. Hb-Lepore was first described by Gerald and Diamond (1958b) in association with the clinical picture of thalassaemia. On starch block electrophoresis Hb-Lepore migrates with $\mathrm{Hb}-\mathrm{S}$ and amounts to approximately IO- $15 \%$ of total haemoglobin in the trait form. There are at least two forms of Hb-Lepore. Baglioni (1962b) has shown that these haemoglobins consist of the
$\mathrm{N}$-terminal part of the $\delta$-chain joined to the C-terminal part of the $\beta$-chain, the total number of amino acids in the new $\delta$ - $\beta$-chain being the same as in the $\beta$-chain. There are several types of Hb-Lepore, which differ in the proportion of $\delta$ - and $\beta$-chain present. In Hb-Lepore Boston, obtained from a subject of Italian origin (Gerald and Diamond, 1958b; Baglioni, 1962b), tryptic peptides $I-5$ are like those in the $\delta$-chain, and $6-$ I I could be either from the $\delta$ - or $\beta$-chain, while I2-I5 are $\beta$-like. Hb-Lepore Hollandia (Neeb, Beiboer, Jonxis, Kaars Sijpesteijn, and Muller, 196I ; Barnabas and Muller, 1962; Baglioni, 1962b) has tryptic peptides $I-3$ from the $\delta$-chain and 4-I5 from the $\beta$-chain (Fig. I0). Several other haemoglobins are probably of the Lepore type: Hb-Pylos (Fessas, Stamatoyannopoulos, and Karaklis, 1962) and Hb-G (Silvestroni and Bianco, 1958). A Hb-Lepore found in a subject of Italian origin has a similar structure to that of $\mathrm{Hb}$ Lepore $_{\text {Boston }}$ (Barkhan, Stevenson, Pinker, Dance, and Shooter, 1964).

Baglioni (1962b) has discussed the genetic event that could have led to the formation of a $\delta$ - $\beta$-polypeptide chain. Two possibilities are mentioned, both of which require the $H b_{\beta}$ and $\mathrm{Hb}$ \& loci to be closely linked (see later). The first possibility is a deletion of part of the $\delta$ and $\beta$ loci with the formation of a new $\delta-\beta$ gene. On this hypothesis it is difficult to understand why the $\delta$ - $\beta$-chain synthesized is the same length as the $\beta$ - or $\delta$-chain. The second, and apparently more likely, situation, which accounts for the

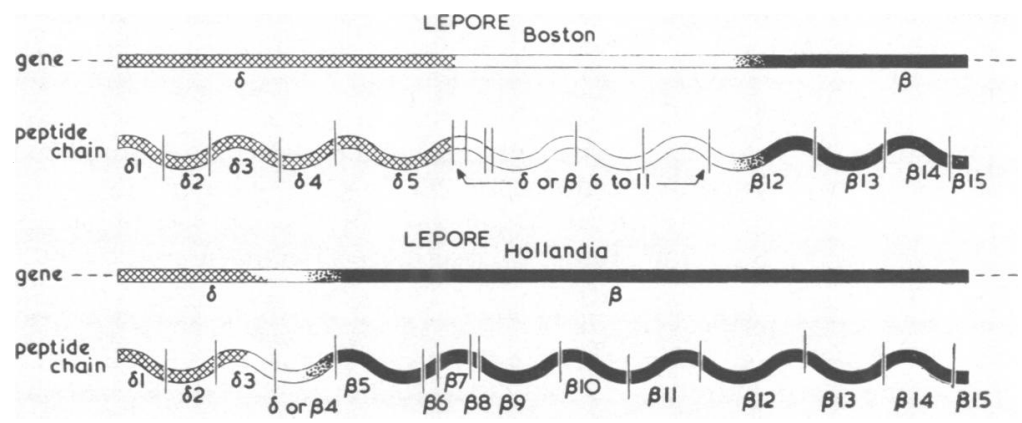

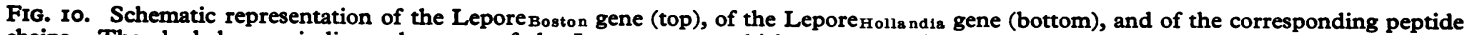
chains. The shaded areas indicate that part of the Lepore genes which appears to be derived from the $\mathrm{Hb}$ gene and that part of the corresponding peptide chains which is $\delta$-like. The area in solid colour indicates that part of the Lepore genes which appears to be derived from the $\mathrm{Hb}_{\mathrm{G}}$ gene and that part of the corresponding peptide chains which is $\beta$-like. The empty areas between shaded and solid colour areas indicate those portions of the genes and of the peptide chains that may be derived from either the Hb $\delta$ or Hb $\beta$ gene. The postulated joining of part of the $\mathrm{Hb} \delta$ gene to part of the $\mathrm{Hb} \beta$ gene has occurred presumably in this area. The lines along the peptide chains indicate schematically the peptide bonds that may be split by trypsin. The resulting peptides are indicated below and are numbered consecutively starting from the $\mathrm{N}$-terminus. The symbols $\delta$ or $\beta$ which precede the peptide numbers indicate whether the corresponding peptides are $\delta$-like or $\beta$-like. (From Baglioni, 1962b, with permission of National Academy of Sciences.) 
joining of the $\beta$ to the $\delta$-gene in such an exactly complementary way, is a non-homologous crossingover between corresponding points of the $\beta$ and the $\delta$ genes, resulting in the formation of unequal products, one of which is Hb-Lepore (Fig. II).

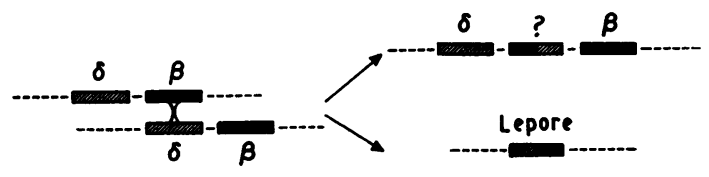

FIG. II. Schematic representation of the postulated non-homologous crossing-over leading to the formation of the Lepore genes. The shaded area indicates the nucleotide sequence corresponding to the $\mathrm{Hb}_{\delta}$ gene. The non-homologous crossing-over is supposed to have occurred in the areas shown as empty in Fig. Io. (From Baglioni, 1962b, with permission of National Academy of Sciences.)

\section{Methods for the Identification of the Abnormal Haemoglobins}

(i) ELECTROPHORESIS. This is the primary method for the detection of any haemoglobin variant. Originally, moving boundary electrophoresis was used, but this was soon replaced by paper electrophoresis, and this method is the most widely used technique. However, a number of the haemoglobins that are associated with disease, such as Hb-Lepore, Hb-St. Mary's, $\mathrm{Hb}-\mathrm{H}$, and $\mathrm{Hb}-\gamma_{4}$ are not easily detected by this procedure, particularly as they are often present in low concentrations, while variants of $\mathrm{Hb}-\mathrm{A}_{2}$ cannot be detected at all. Starch gel electrophoresis has a much greater sensitivity and is now the method of choice. Suitable buffer systems have been previously described (Gammack, Huehns, Shooter, and Gerald, 1960), but the greatest over-all sensitivity can be achieved using a tris-E.D.T.A.-borate buffer system (O. Smithies, unpublished). This is sensitive both to the rapidly migrating haemoglobins such as the non- $\alpha$-chain haemoglobins, $\mathrm{Hb}-\beta_{4}$ and $\mathrm{Hb}-\gamma_{4}$, as well as to 'slow' minor components. The usual $p \mathrm{H}$ used is 8.6 (I09 g. tris [2-amino-2-(hydroxy-methyl) propane- $\mathrm{I}: 3 \mathrm{diol}$ ] 5.84 g. disodium E.D.T.A., 30.9 g. boric acid/1., diluted 1 to 20 for making the gel and $I$ to 7 for the buffer vessels). One of the advantages of this system is that concentrated haemolysates can be applied without overloading the gel, thus facilitating the detection of minor components. The sensitivity can be further increased by staining the gel with benzidine or $o$-tolidine. Another advantage is that $\mathrm{I} \%$ of $\mathrm{Hb}-\mathrm{F}$ can be detected. In order to detect the presence of $\mathrm{Hb}-\alpha^{A}$, which remains on the origin in this system at $p \mathrm{H} 8.6$, the gel can be made at $\mathrm{pH} 8 \cdot 3$, using $69 \cdot 9 \mathrm{~g}$. tris/litre instead oft IO9 $\mathrm{g}$.

The relative concentration of $\mathrm{Hb}-\mathrm{A}_{2}$, which is of some importance in the diagnosis of thalassaemia trait, is best estimated by starch block electrophoresi (Kunkel, 1954). It can also be estimated by column chromatography on DEAE (Huisman and Dozy, 1962). In practice, these methods are timळ consuming and open to error if not carried ouf carefully. An estimate to determine whether: $\mathrm{Hb}-\mathrm{A}_{2}$ is raised can be obtained by careful comet parison of the $\mathrm{Hb}-\mathrm{A}_{2}$ zones obtained on starch ge? electrophoresis from normal haemolysates with those from suspected thalassaemia minor afteiv adjustment of the haemoglobin concentration in both.

Agar gel is also a good supporting medium fo electrophoresis of haemoglobins (Yakulis, Heller, Josephson, and Singer, 1960; Shibata and Iuchi3 1962) and gives some special separations wher used at acid $p \mathrm{H}$ (Robinson et al., r957).

(ii) Chromatography. This method is mainlo used for the purification of haemoglobins before chemical analysis and has been carried out on IRC 50 (Allen et al., I958; Clegg and Schroeder? 1959; Schnek and Schroeder, 196I; Jones anci Schroeder, 1963), carboxymethylcellulose (CMC) (Huisman et al., 1958) or diethylaminoethylcellu을 lose (DEAE) (Huisman and Dozy, I962). Huismap and Prins (1955) have described a qualitative method which has often been used for the identifi cation of haemoglobins (see Lehmann, 1960).

(iii) Hybridization. This method, first deviseç्व by Itano and his co-workers (Itano and Singer 1958; Itano, Singer, and Robinson, 1959), is usec in the identification of the abnormal chains of क haemoglobin variant. A suitable micro-adaptation of the original method, using starch gel for the analysis of the haemoglobins formed, has beent described (Gammack et al., 1960). More recently the formation of hybrid haemoglobins betweerf human and canine haemoglobins has been used (seêt Fig. 12) (Itano and Robinson, 1959; Robinson and Itano, 1960; Huehns, Shooter, and Beaven, 1962a; Shibata, Iuchi, Ueda, Miyaji, and Takeda? 1962b).

(iv) 'Fingerprinting'. This method is used to ${ }^{2}$ identify the abnormal tryptic peptide and is fully described by Ingram (1958) and Baglioni (196I) The globin of the purified abnormal haemoglobin? is prepared (Anson and Mirsky, 1930; Rossi- 


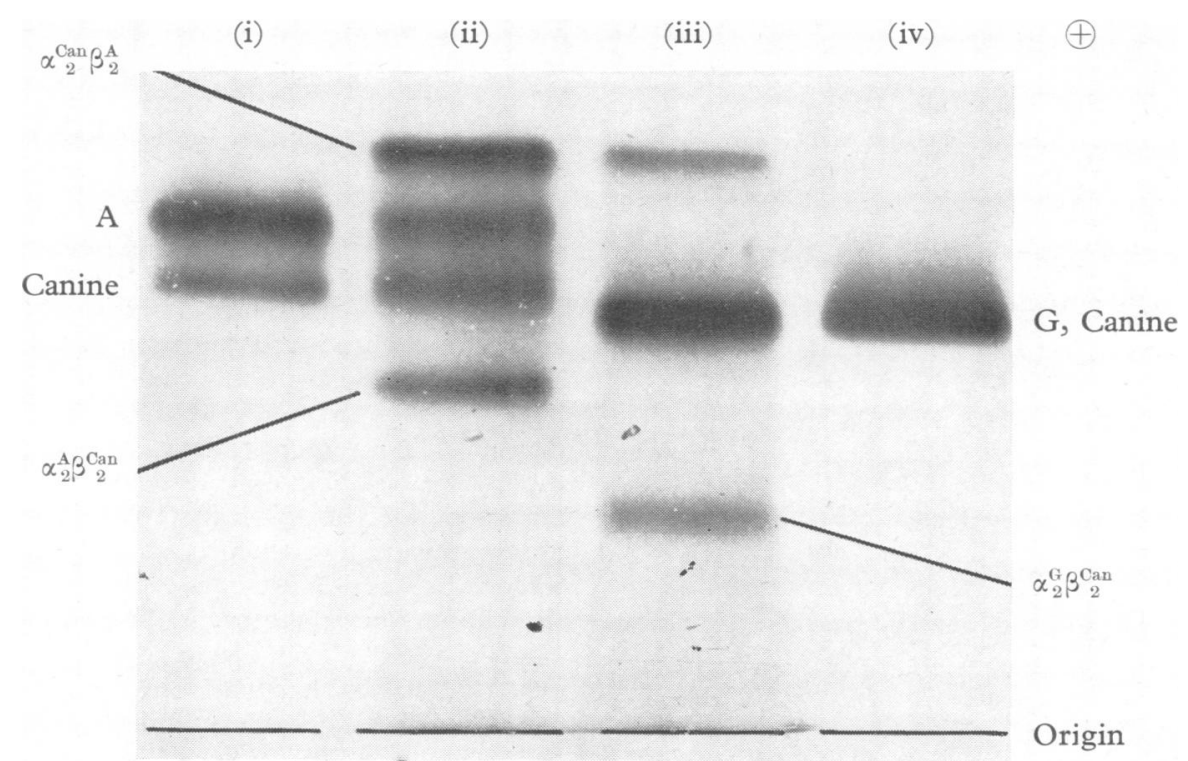

FIG. I2. The formation of hybrid haemoglobins between $\mathrm{Hb}-\mathrm{A}$ and canine haemoglobin and between $\mathrm{Hb}-\mathrm{G}$ and canine haemoglobin: (i) Hb-A + Hb-Canine control; (ii) Hb-A + Hb-Canine dissociated and recombined; (iii) $\mathrm{Hb}-\mathrm{G}+$ $\mathrm{Hb}-\mathrm{Canine}$ dissociated and recombined; and (iv) $\mathrm{Hb}-\mathrm{G}+\mathrm{Hb}-\mathrm{Canine}$ control. Since Hb-G has the structure $\alpha_{\alpha^{\mathrm{G}} \beta_{2}}$ it forms the same hybrid $\alpha_{2}^{\mathrm{Can}} \beta_{2}^{\mathrm{A}}$, as does $\mathrm{Hb}-\mathrm{A}$, but the second hybrid $\alpha_{2}^{\mathrm{G}} \beta_{2}^{\mathrm{Can}}$ is different from $\alpha_{2}^{\mathrm{A}} \beta_{2}^{\mathrm{Can}}$. This method can be used to find which chain is abnormal in a haemoglobin variant (from Huehns and Shooter, 1964a; with kind permission of Blackwell Scientific Publications Ltd.).

Fanelli, Antonini, and Caputo, 1958; Teale, 1959) and digested with trypsin. The resulting peptide mixture is then analysed by high-voltage electrophoresis, followed by chromatography at right angles. The resulting peptide pattern or 'fingerprint' is compared with that prepared from normal haemoglobin (Fig. 13). The abnormal peptide is then eluted and the amino acid sequence determined. One of the drawbacks of this method is that some of the peptides formed are insoluble, the so-called 'core'. Recently, Jones (1964) has aminoethylated the cysteinyl residues in haemoglobin by treatment of the globins with ethylenimine at $p \mathrm{H} 8.6$ in $8 \mathrm{M}$ urea. The S-(2-aminoethyl)-cysteinyl ('pseudolysine') residues formed lead to several more sites in the 'core' of the molecule, which are cleaved by trypsin, and thus no insoluble peptides are formed. The peptide mixture formed can then be conveniently separated by automatic column chromatography.

One of the questions in the examination of the abnormal haemoglobin is how far the investigation of each separate sample containing a haemoglobin variant should be taken. From the clinical point of view, only a limited amount of work is necessary. The ability of the red cells to sickle on reduction with metabisulphite would distinguish between the presence of $\mathrm{Hb}-\mathrm{D}$ and $\mathrm{Hb}-\mathrm{S}$. The identification of some of the other abnormal haemoglobins, such as $\mathrm{Hb}$-Lepore, $\mathrm{Hb}-\mathrm{H}, \mathrm{Hb}-\mathrm{M}$, and the unstable haemoglobins, is suggested by the associated clinical picture. For the remaining haemoglobins, the identification is often presumptive, depending on careful comparison with known markers. The relative proportion of the abnormal haemoglobin found in the heterozygote and the origin of the patient are both taken into consideration. From the biochemical geneticist's point of view, no identification is complete until the abnormal amino acid residue has been located. Even haemoglobins apparently identical by electrophoresis and chromatography as well as by hybridization are found to be different by fingerprinting, for example, the various types of $\mathrm{Hb}-\mathrm{D}$ and $\mathrm{Hb}-\mathrm{J}$ mentioned earlier. On the other hand, an identical fingerprint is found in Hb-J Rambam and Hb-Seattle. One of these has a glycine residue replaced by aspartic acid in tryptic peptide IX, while in the other an alanine is replaced by glutamic acid in the same peptide. In practice, rare variants found in ethnically different populations probably merit detailed study. 

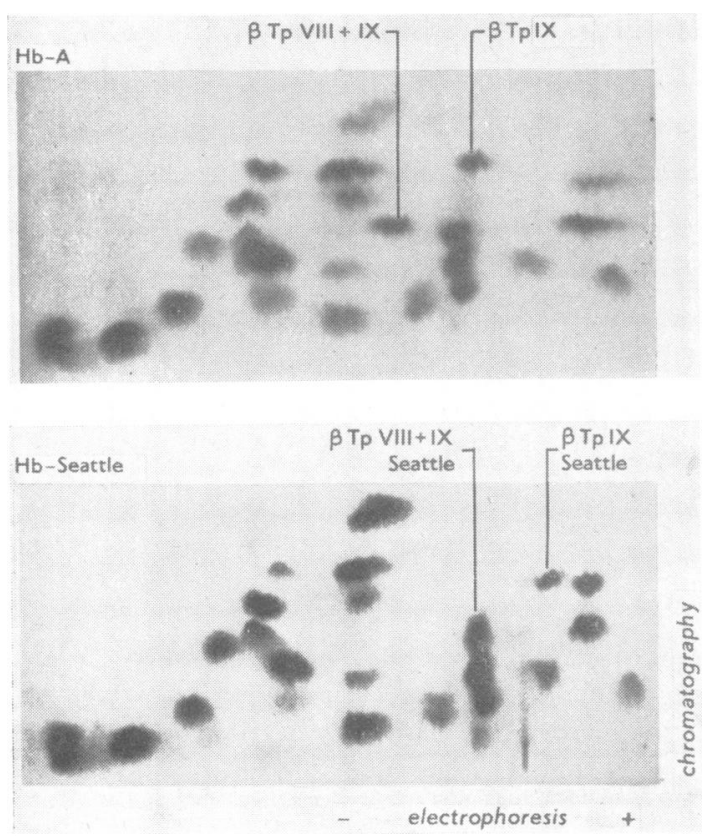

Fig. 13. The fingerprints of $\mathrm{Hb}-\mathrm{A}$ and the variant $\mathrm{Hb}$-Seattle. The peptides were stained by spraying with ninhydrin. Electrophoresis in pyridine acetic acid buffer $\mathrm{pH} 6.4$ followed by chromatography in iso-amyl alcohol-pyridine-water solvent. (Photographs supplied by Mr N. Dance.) (From Huehns and Shooter, 1964a; with kind permission of Blackwell Scientific Publications Ltd.)

(v) Separation of the Polypeptide Chains of $\mathrm{Hb}-\mathrm{A}$. The peptide analyses described above are very much simplified if the $\alpha$ - and $\beta$-chains are first separated. This can be achieved by column chromatography on Amberlite IRC 50 in a urea gradient at $p \mathrm{H}_{2}$ (Wilson and Smith, 1959) or by countercurrent distribution (Hill and Craig, 1959). Hayashi (196I) has separated the chains by differential precipitation. The globin chains can also be obtained by starch gel electrophoresis (Muller, 1960). It is much more difficult to separate the polypeptide chains with their haem groups attached, and chromatography at acid $p \mathrm{H}$ gives only small yields (Huehns et al., I96Ib). More recently, striking separations of the $\alpha$ - and $\beta$-chains of $\mathrm{Hb}-\mathrm{A}$ with their haem groups still attached have been obtained after reacting the haemoglobin with an excess of sodium para-(Chloromercuri) benzoate (PCMB) in the presence of $0.2 \mathrm{M}-\mathrm{NaCl}$ at $p \mathrm{H} 6.0$ (R. Bucci and C. Frontacelli, unpublished).

\section{Other Biochemical Studies}

(i) Immunological Studies of Human HaemoGLOBINS. Immunological studies on haemoglobin have been reported, and antibodies to $\mathrm{Hb}-\mathrm{A}, \mathrm{Hb}-\mathrm{F}$, and $\mathrm{Hb}-\mathrm{A}_{2}$ have been prepared (Chernoff, 1953a, Westendorp Boerma, Huisman, and Mandema, 1960; Heller, Yakulis, and Josephson, 1962a; Schneider and Arat, 1964; Askonas and Smyth, 1964). Rucknagel and Chernoff (1955) have used을 anti-Hb-F to measure small amounts of $\mathrm{Hb}-\mathrm{F}$ in $\frac{\bar{\sigma}}{\widehat{\phi}}$ normal adults and during pregnancy.

Recently, Westendorp Boerma and Huismano (1964) have produced antisera in rabbits which, $\rightarrow$ after suitable absorption procedures, can differen-.tiate between $\mathrm{Hb}-\mathrm{S}$ and $\mathrm{Hb}-\mathrm{C}$, a remarkable $\vec{\omega}$ degree of specificity when it is remembered thato these haemoglobins only differ by one amino acid $\overline{3}$ on each of the $\beta$-chains. Another interesting observation is that there is an immunological dif-ference between horse oxy- and deoxyhaemoglobin ${ }_{\infty}$ (Reichlin, Bucci, Antonini, Wyman, and Rossi-o Fanelli, 1964). This observation provides further? evidence that oxyhaemoglobin has a different con $\overline{3}$ formation from deoxyhaemoglobin, as has alreadyo been shown by the studies of Muirhead and Perutzs (1963) referred to above.

(ii) The Site of Chromium Attachment tog HAEMOGLOBIN. Radioactive chromium $\left({ }^{51} \mathrm{Cr}\right)$ is commonly used to label red cells for in vivo redo cell survival studies. It is known that it is attacheds to the haemoglobin molecule (Gray and Sterling. 1950). Experiments by Chernoff (I96I) suggesio that the site of attachment might be on the $\alpha$-chain $\AA$ However, the work of several other investigator $\vec{\delta}$ (Pearson and Vertrees, 196I; Heisterkamp and Ebaugh, 1962; Malcolm, Ranney and Jacobs, 1963) makes it more likely that it is mainly attached to the $\beta$-chain. Perhaps the method of labelling red cells with ${ }^{51} \mathrm{Cr}$ is critical.

\section{II: THE GENETIC CONTROL OF HAEMOGLOBIN SYNTHESIS}

\section{Structural Loci}

Adult Haemoglobin. In 1949, Pauling et al. showed that the haemoglobin of patients with sickle cell disease differed from that of normat persons and their studies indicated that,

'two normal genes lead to the production of onlos normal haemoglobin; one normal and one abnorms gene lead to the production of both normal and sickle haemoglobin and two abnormal genes lead to the production of only sickle haemoglobin'.

At about the same time, the family studies of Beet (1949) and of Neel (1949), using the sickling 


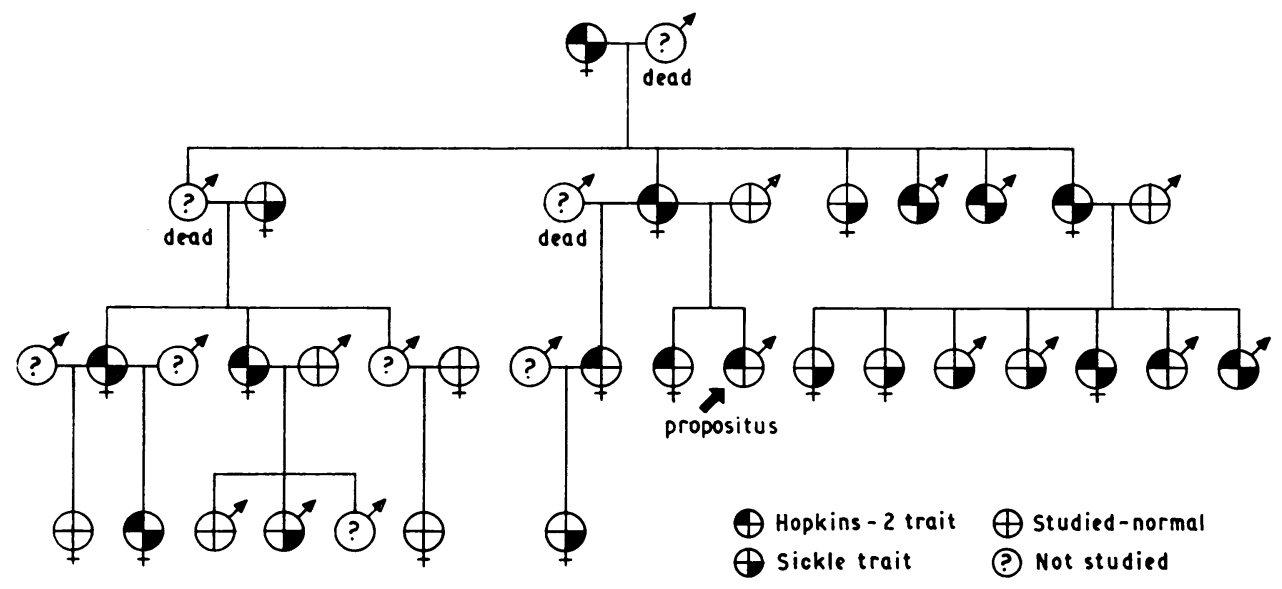

FIG. I4. Pedigree of 'Hopkins 2 pedigree' showing independent segregation of the genes for Hb-S and Hb-Hopkins 2 (from Smith and Torbert, 1958; and Bradley et al., 1961).

test, also demonstrated the inheritance of the disease. Shortly after this, a number of abnormal haemoglobins (Hb-C, Hb-D, Hb-E, etc.) were discovered which showed similar inheritance, and Itano (1953) suggested that because individuals with both $\mathrm{Hb}-\mathrm{C}$ and $\mathrm{Hb}-\mathrm{S}$ carried no $\mathrm{Hb}-\mathrm{A}$, the genes responsible for these two haemoglobins were alleles. This was shortly afterwards confirmed by the family studies of Ranney (1954). A similar allelism was proposed for $\mathrm{Hb}-\mathrm{D}$, Hb-E, and Hb-G (Neel, 1956). This rests mainly on the finding that double heterozygotes carry no $\mathrm{Hb}-\mathrm{A}$, rather than on classical genetic analysis. The discovery by Smith and Torbert (1958) of a family where two abnormal

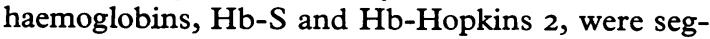
regating independently, and the finding that one had abnormal $\beta$-chains while the other had abnormal $\alpha$-chains, led to the present concept of the genetic control of haemoglobin synthesis (Itano et al., 1959).

Because the abnormal haemoglobins have either abnormal $\alpha$-chains or abnormal $\beta$-chains, it was suggested that these were controlled by separate genetic loci (Itano and Robinson, 1959; Ingram, 1959). Studies of several families (see Fig. 14) (Smith and Torbert, 1958; Itano et al., 1959; Atwater, Schwartz, and Tocantins, I96ob; Baglioni and Ingram, r96I ; Raper, Gammack, Huehns, and Shooter, 1960) in which both $\alpha$-chain and $\beta$-chain variants were segregating and in which some individuals had inherited both abnormalities showed that the locus controlling the synthesis of the $\alpha$ - chains, the so-called $\mathrm{Hb}_{\alpha}$ locus, was not linked to that controlling the $\beta$-chain, the so-called $\mathrm{Hb}_{\beta}$ locus. Furthermore, those individuals that had inherited both abnormalities carried not only both abnormal haemoglobins but also $\mathrm{Hb}-\mathrm{A}$ and a fourth haemoglobin with both abnormal $\alpha$ - and $\beta$-chains (Raper et al., 1960; Baglioni and Ingram, 196I). On the basis of all these findings, a hypothesis for the genetic control of synthesis of $\mathrm{Hb}-\mathrm{A}$ was developed (Itano and Robinson, 1960; Raper et al., 1960; Baglioni and Ingram, 196I).

The synthesis of the $\alpha$ - and $\beta$-chains of Hb-A is controlled by pairs of genes at different genetic loci, and the genotype can conveniently be written $H b_{\alpha}^{A} H b_{\alpha}^{A} H b_{\beta}^{A} H b_{\beta}^{A}$ (the superscript $A$ indicating that the gene is controlling the synthesis of a normal polypeptide chain). Each gene at each locus indirectly determines the synthesis of a particular type of polypeptide chain. These then associate to form the haemoglobins found in vivo (Fig. 15).

Those individuals who inherit one abnormal gene will make two haemoglobins (Fig. I6).

If a person inherits two abnormal genes, three different situations can arise.

(i) A person can inherit two abnormal genes of the same type, as, for example, in the genotype $H b_{\alpha}^{A} H b_{\alpha}^{A} \quad H b_{\beta}^{C} / H b_{\beta}^{C}$. In these subjects, only $\alpha^{A}$ - and $\beta^{C}$-chains are formed, and only $\mathrm{Hb}-\mathrm{C}$ $\left(\alpha_{2}^{\mathrm{A}} \beta_{2}^{\mathrm{C}}\right)$ is found in the red cells. The inheritance of two genes of the same type usually leads to a 


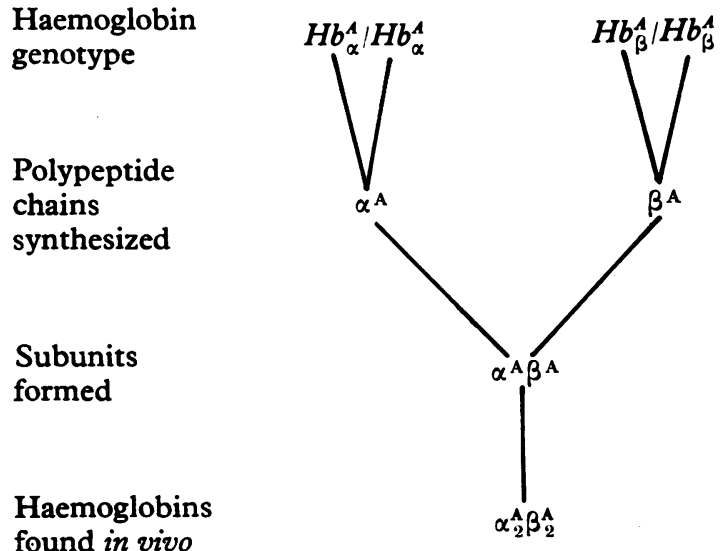

$\mathrm{Hb}-\mathrm{A}$

Fig. 15. The genetic control of the synthesis of haemoglobin A in a normal individual (from Huehns and Shooter, 1964a).

mild haemolytic disease, such as $\mathrm{Hb}-\mathrm{C}$ disease, $\mathrm{Hb}-\mathrm{E}$ disease, etc.

(ii) When two different abnormal genes occur at the same locus, as, for example, in the genotype

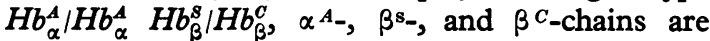
made, leading to the formation of only $\mathrm{Hb}-\mathrm{S}$ and $\mathrm{Hb}-\mathrm{C}$.

(iii) Finally, if two different mutations occur, one

Haemoglobin

genotype

Polypeptide

chains

synthesized

Subunits

formed

Haemoglobins

found in vivo

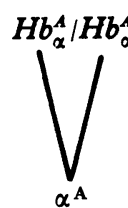

$H b_{\beta}^{\Lambda} / H b \underset{\beta}{\widehat{S}}$

Hb-A Hb-S
Fig. 16. The genetic control of the synthesis of haemoglobin in a
sickle cell heterozygote (from Huehns and Shooter, 1964a). with four adult haemoglobins mentioned earlier, four different polypetide chains are synthesized, leading to the formation of four haemoglobin species (Fig. 17).

In this connexion, it is of interest that individualsळ with clinically severe sickle cell anaemia have been reported who carry two abnormal haemoglobinsoํำ

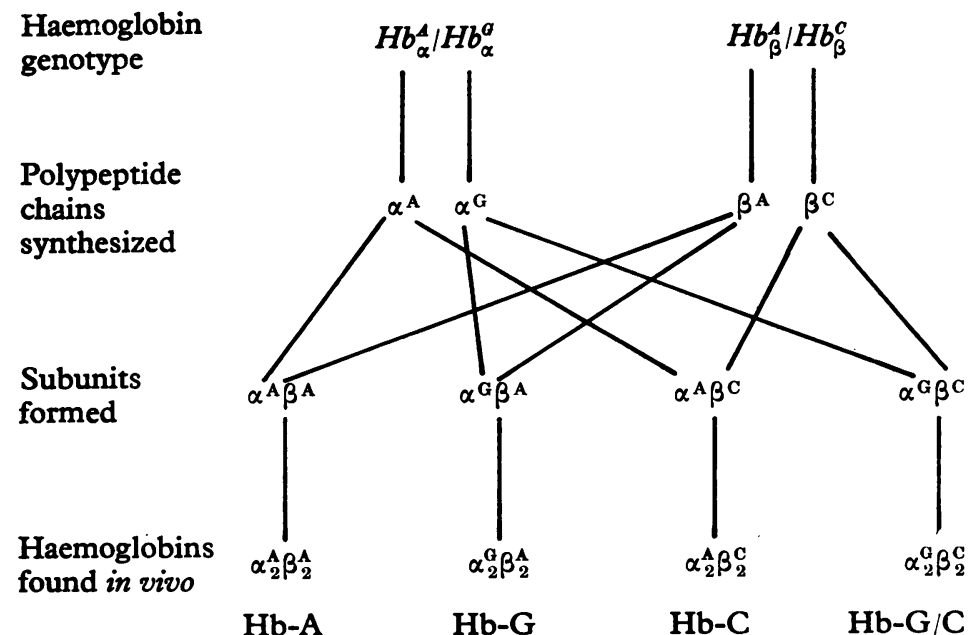

FIG. I7. The genetic control of the synthesis of haemoglobin in an individual heterozygous for the $\mathrm{Hb}-\mathrm{C}$ trait and the $\mathrm{Hb}-\mathrm{G}_{\alpha}$ trait (from Huehns and Shooter, 1964a). 


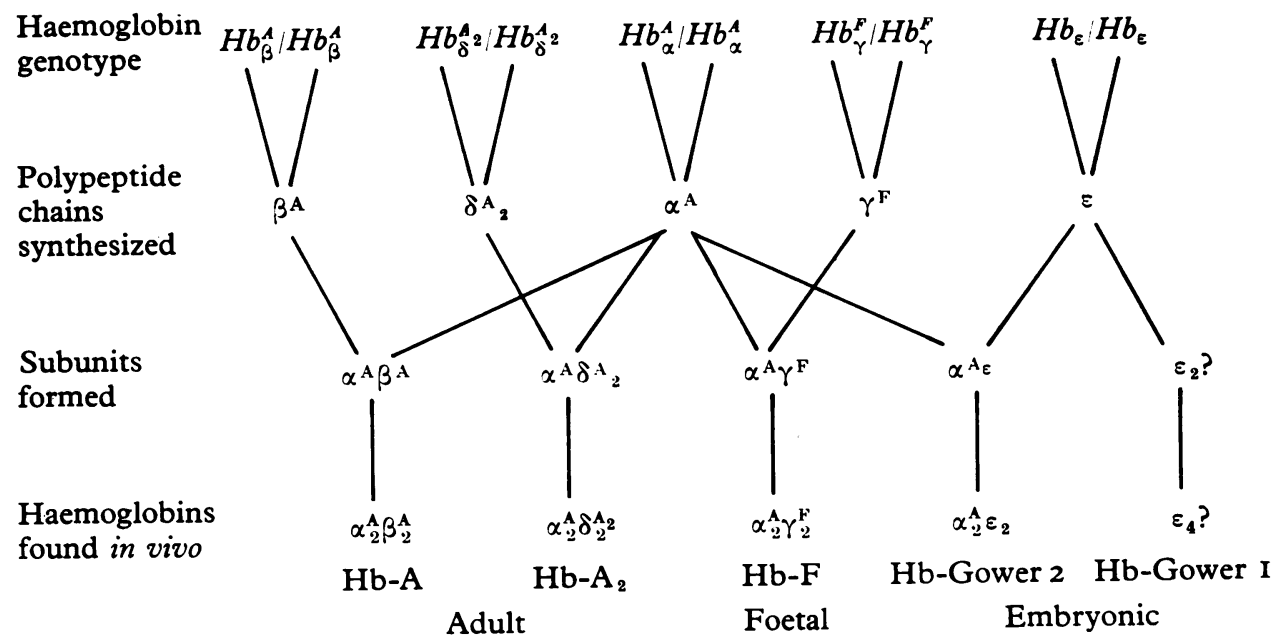

FIG. 18. The genetic control of the synthesis of normal adult haemoglobins, $\mathrm{Hb}-\mathrm{A}$ and $\mathrm{Hb}-\mathrm{A}_{2}$, foetal haemoglobin, and the embryonic haemoglobins, Hb-Gower I and $\mathrm{Hb}-\mathrm{Gower} 2$ (from Huehns and Shooter, 1964a).

(Pugh, Monical, and Minnich, 1964; Hall-Craggs, Marsden, Raper, Lehmann, and Beale, 1964). In these individuals there is homozygosity at the $\mathrm{Hb}_{3}$ locus for the $\beta^{\text {s }}$ gene but heterozygosity at the $\mathrm{Hb}$, locus, giving the genotype $H b_{\alpha}^{A} / H b_{\alpha}^{G} H b_{\beta}^{S} H b_{\beta}^{S}$. Clearly, two haemoglobins, $\mathrm{Hb}-\mathrm{S}\left(\alpha_{2}^{\mathrm{A}} \beta_{2}^{\mathrm{S}}\right)$ and Hb-G S $\left(\alpha_{2}^{\mathrm{G}} \beta_{2}^{\mathrm{S}}\right)$ will be made, and, as both contain $\beta^{s}$-chains, the patient clinically has sickle cell disease.

Haemoglobins $A_{2}$ and F. The genetic control of synthesis of $\mathrm{Hb}-\mathrm{A}_{2}$ and $\mathrm{Hb}-\mathrm{F}$ follows the same pattern as that of $\mathrm{Hb}-\mathrm{A}$. As the $\alpha$-chains of the normal human haemoglobin are all identical, it has been suggested that these arise from a common metabolic pool and thus are controlled by the same genetic locus (Huehns and Shooter, I96ra). The non- $\alpha$-chains of $\mathrm{Hb}-\mathrm{A}_{2}$ and $\mathrm{Hb}-\mathrm{F}$, the $\delta$ - and $\gamma$-chains respectively, are controlled by their own genetic loci, the $\mathrm{Hb}_{\delta}$ and $\mathrm{Hb}_{\gamma}$ loci. Although no genetic studies on the embryonic haemoglobins have been possible, it is postulated that there is a separate genetic locus for the $\varepsilon$-chain. The outline for the control of synthesis of the normal haemoglobins would then be as in Fig. 18. The above hypothesis is supported by the discovery of variants of $\delta$ - and $\gamma$-chains mentioned earlier. The idea that the $\alpha$-chains of $\mathrm{Hb}-\mathrm{F}, \mathrm{Hb}-\mathrm{A}_{2}$, and $\mathrm{Hb}-\mathrm{A}$ arise from a common metabolic pool implies that if abnormal $\alpha$-chains are being synthesized, not only will a Hb-A variant be found but also the corres- ponding variants of $\mathrm{Hb}-\mathrm{F}$ and $\mathrm{Hb}-\mathrm{A}_{2}$ with abnormal $\alpha$-chains (Fig. I9).

Studies of several people synthesizing abnormal $\alpha$-chains have, in fact, shown that they carry not only the corresponding $\mathrm{Hb}-\mathrm{A}$ variant but also the corresponding variant of $\mathrm{Hb}-\mathrm{A}_{2}: \mathrm{Hb}-\mathrm{G}_{2}$ (Shooter, Skinner, Garlick, and Barnicot, 1960; Huehns and

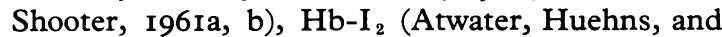
Shooter, I96r ; Boulard, Cosset, Destaing, Duzer, Jonxis, Muller, and Portier, I96I), Hb-Q ${ }_{2}$ (Dormandy, Lock, and Lehmann, I96I), $\mathrm{Hb}-\mathrm{No}_{2}$ (Baglioni, I962c), $\mathrm{Hb}-\mathrm{D}_{2}$ and $\mathrm{Hb}-\mathrm{G}_{2}$ (Weatherall and Boyer, 1962) and $\mathrm{Hb}-\mathrm{F}$ : $\mathrm{Hb}-\mathrm{G} / \mathrm{F}$ and $\mathrm{Hb}-\mathrm{D} / \mathrm{F}$ (Minnich et al., I962; Weatherall and Boyer, 1962; Weatherall and Baglioni, I962), Hb-I F (Ranney, O'Brien, and Jacobs, I962).

\section{'Controller Genes' in Haemoglobin Synthesis}

During development, the synthesis of embryonic haemoglobin is succeeded by the synthesis of foetal haemoglobin which, in turn, is replaced by the adult haemoglobins, $\mathrm{Hb}-\mathrm{A}$ and $\mathrm{Hb}-\mathrm{A}_{2}$, shortly after birth. This can be explained in terms of regulatory genes which control the rates of synthesis of various polypeptide chains, a concept derived from work in bacterial genetics (Jacob and Monod, I96I). A mutation at one of these controller loci might result in changes in the rate of synthesis of a polypeptide chain without any alteration in its structure, and it has been suggested that 'the hereditary persistence 


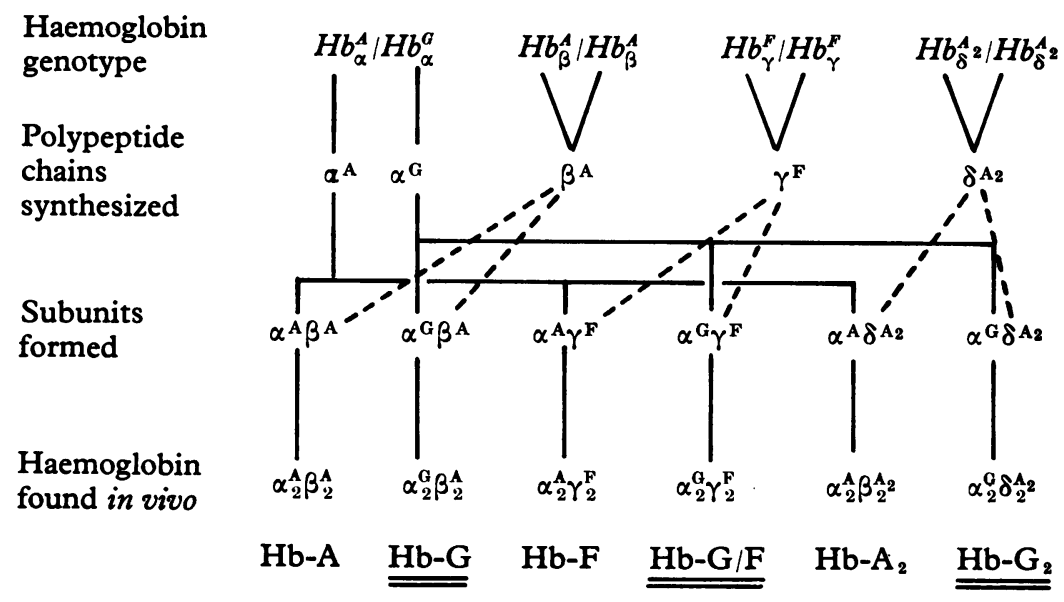

FIG. 19. The genetic control of haemoglobin in a subject heterozygous for Hb-G $\alpha$ trait, showing the formation of the three normal haemoglobins $\mathrm{Hb}-\mathrm{A}, \mathrm{Hb}-\mathrm{F}$, and $\mathrm{Hb}-\mathrm{A}_{2}$, as well as the corresponding $\alpha$-chain variants $\mathrm{Hb}-\mathrm{G}, \mathrm{Hb}-\mathrm{G} / \mathrm{F}$, and $\mathrm{Hb}-\mathrm{G}_{2}$.

of foetal haemoglobin' and 'thalassaemia' are of this type (Neel, 1961; Motulsky, I962; Sturgeon, Schroeder, Jones, and Bergren, I963; Zuckerkandl, 1964).

\section{Linkage Relationships of the Loci Controlling the Synthesis of Haemoglobin}

(i) $\mathbf{H b} \mathbf{b}_{\alpha}$ and $\mathbf{H b} \mathbf{b}_{\beta}$ Loci. Studies of several families in which both $\alpha$ - and $\beta$-chain variants of $\mathrm{Hb}-\mathrm{A}$ are segregating (quoted above) show that the locus controlling the synthesis of the $\alpha$-chains is not linked to that of the $\beta$-chains. It has also been shown that neither loci are closely linked to genetic loci controlling certain blood or serum groups (Bradley, Brawner, and Conley, I96r).

(ii) $\mathrm{Hb}_{\beta}$ and $\mathrm{Hb}_{\delta}$ Loci. There are several families in which a $\mathrm{Hb}-\mathrm{A}_{2}$ variant with abnormal $\delta$-chains segregates with a $\beta$-chain variant and no cross-overs have been detected, though this could have taken place in 45 instances (Ceppellini, 1959; Horton et al., 1961; Ranney et al., 1963; Boyer Rucknagel, Weatherall, and Watson-Williams, 1963; Horton and Huisman, 1963). These family studies thus indicate that the locus controlling the synthesis of the $\delta$-chain is closely linked to that for the $\beta$-chain. The family study of Huisman, Punt, and Schaad (I96I) showed that the locus for $\delta$-chains was linked to that for $\beta$-thalassaemia, and as the latter was linked or allelic to that controlling the synthesis of $\beta$-chains (see below), it also strengthened the finding of $\delta$ to $\beta$ linkage. (iii) $\mathbf{H b}_{\beta}$ and $\mathrm{Hb}_{\gamma}$ Loci. At the present time, $\vec{\varphi}$ no studies of families in which variants of both $\mathrm{O}$ the $\gamma$ - and $\beta$-chains occur have been reported, and 0 the question of whether the locus controlling the synthesis of the $\gamma$-chains is linked to the loci controlling the synthesis of $\beta$ - and $\delta$-chains cannot be definitely answered. However, studies of $\frac{\alpha}{\otimes}$ families in which the $\beta$-chain variants $\mathrm{Hb}-\mathrm{S}$ or $\varrho$ $\mathrm{Hb}-\mathrm{C}$ are segregating with a gene causing persistence of foetal haemoglobin, the so-called 'high-F gene', indicate that the 'high-F' gene is closely linked (or allelic) to the $\beta$-chain locus (Rucknagel and Neel, 196r; Conley, Weatherall, Richardson, Shepard, and Charache, 1963). At present, it seems reasonable to assume that the 'high-F' gene might be at, or closely linked to, the locus for the $\gamma-$ chains, and this leads to the conclusion that $\mathrm{Hb}_{\curlyvee}$ and $\mathrm{Hb}_{\beta}$ loci are closely linked.

(iv) Linkage Relationships of the Thalas- $\frac{T}{O}$ saemia Loci. The results of studies of families in which both $\beta$-thalassaemia (see later) and haemo- N globins $S, C$, or $B_{2}$ are segregating have been reviewed by Rucknagel and Neel (I96I) and $O$ Motulsky (1964b) and indicate that the gene causing $\omega$ $\beta$-thalassaemia is closely linked or allelic to the $\beta$ ? and $\delta$ structural loci. There appears to be only one clear instance of a cross-over between the $\beta$ - $\mathbb{D}$ thalassaemia gene and that for an abnormal haemoglobin, in this case, $\mathrm{Hb}-\mathrm{B}_{2}$ (Moore and Pearson, r964). Motulsky (1964b) tentatively interprets this finding as evidence in support of the idea that the locus for $\beta$-thalassaemia is outside the $\beta \delta$-structural 
locus but closely linked to it. Clearly, further family studies to resolve this point are needed.

The $\alpha$-thalassaemia locus, like the $\mathrm{Hb}_{\alpha}$ structural locus, is not linked to the $\mathrm{Hb}_{\beta}$ structural locus (Tuchinda, Rucknagel, Minnich, Boonyaprakob, Balankura, and Suvatee, 1964). There are no data yet to show whether $\alpha$-thalassaemia trait is linked to the $\mathrm{Hb}_{\alpha}$ structural locus. The biochemical interaction between $\alpha$-thalassaemia and $\alpha$-chain variants of haemoglobin is similar to that between $\beta$ thalassaemia and the various $\beta$-chain haemoglobin variants, and this suggests that the genetical situation might be analogous to that for $\beta$-thalassaemia.

\section{The Problem of the Inheritance of Haemoglobin $M$}

Although, in several families, Hb-M follows the semi-dominant pattern of Mendelian inheritance seen with other abnormal haemoglobins, in several instances the disease is not found in either of the parents of one of the affected individuals. Three families (Sahawi, Hunger, and Betke, 1962; Josephson, Weinstein, Yakulis, Singer, and Heller, 1962; Heller, Weinstein, Yakulis, and Rosenthal, 1962b) like this have now been studied in detail, and the determination of a number of blood group characters in various members of the families is consistent with the stated parentage (Sahawi et al., I962; Josephson et al., 1962). This could be explained if the formation of methaemoglobin in vivo in these individuals only occurred by the interaction of the haemoglobin abnormality with some other, as yet undiscovered, factor. This explanation is ruled out by the absence of any haemoglobin abnormality in detailed studies of the unaffected family members. It would then appear that the occurrence of $\mathrm{Hb}-\mathrm{M}$ in these individuals is due to new mutations.

\section{Haemoglobins and Chromosomal Abnormalities}

It appears firmly established, as outlined in the preceding section, that haemoglobin synthesis is controlled by a number of genetic loci, one structural locus for each of the different polypeptide chains. There are probably also a number of regulatory loci. One of the most intriguing questions is on which of the 46 chromosomes these loci are situated. The inheritance of the abnormal haemoglobins indicates that they are not X-linked. Recently, the haemoglobins from patients with the various chromosomal triplications, the so-called trisomies, have been investigated. Huehns, Hecht, Keil, and Motulsky (1964c) and Huehns et al. (1964a, b) report that, in trisomy $13-15$, trace amounts of the embryonic haemoglobin Hb-Gower 2 persist until birth and that $\mathrm{Hb}-\gamma_{4}$ is present in slightly increased amounts. They also found that in six older children with the same trisomy, $\mathrm{Hb}-\mathrm{F}$ was increased. The data on the $\mathrm{Hb}-\mathrm{F}$ in these individuals are still very scanty, but it appears that its disappearance is delayed as compared to that of normal individuals. Powars, Rohde, and Graves (1964) have also found persistence of $\mathrm{Hb}-\mathrm{F}$ in their patient with trisomy 13-15. These results can be interpreted in several ways, but raise the possibility that some of the loci controlling haemoglobin synthesis are located on the chromosome triplicated in this syndrome. However, another view is that these findings represent a more generalized immaturity in biochemical development. The haemoglobins found in trisomy $17-18$ and trisomy 2I-22 (Down's syndrome) have also been studied. Huehns et al. (1964c) report no difference from normal in both conditions (one patient with trisomy I7-I 8 and six with trisomy 21-22). D. L. Rucknagel (personal communication) has found that in $10 \%$ of Negroes with Down's syndrome, $\mathrm{Hb}-\mathrm{F}$ is increased ( 90 cases studied).

Further information will be obtained if similar patients can be found who also have an abnormal haemoglobin, since the ratio of normal to abnormal haemoglobin might differ if the triplicated chromosome carries one or more of the loci controlling haemoglobin synthesis. D. L. Rucknagel (personal communication) has studied the $\mathrm{Hb}-\mathrm{A}$ to $\mathrm{Hb}-\mathrm{S}$ ratios in patients with trisomy $2 \mathrm{I}-22$ and found them to be normal. Of course, if a patient with one of the trisomies carries, say, $\mathrm{Hb}-\mathrm{S}, \mathrm{Hb}-\mathrm{C}$, and $\mathrm{Hb}-\mathrm{A}$, he must then have inherited three different $\mathrm{Hb}_{\beta}$ structural genes, one on each of the triplicated chromosomes. Although the combination of a mating of a patient with $\mathrm{Hb}-\mathrm{S}-\mathrm{C}$ disease with a normal person giving rise to an infant with one of the trisomies must be extremely rare, the search for and detailed study of such patients may lead to further advances in this interesting field.

\section{The Abnormal Haemoglobins and the Genetic Code}

In the genetic control of protein synthesis, it is postulated that the amino acid sequence of any protein is represented on the chromosome by a definitive sequence of bases in the DNA. Crick, Barnett, Brenner, and Watts-Tobin (I96I), from their genetic experiments in bacteria, have suggested that each amino acid is coded for by three (or perhaps a multiple of three) bases and that each 
'code word' is specific for one amino acid. The different code words are non-overlapping and follow directly one after another. It appears that the code is 'degenerate', that is, there may be more than one code word for any particular amino acid. In order that synthesis of protein can take place, the DNA code is transcribed on to the so-called messenger RNA (mRNA) which is thought to form the template on the ribosomes on which the protein is synthesized. Each amino acid is added at the right place because of the complementary fit of the amino acid transfer RNA. This hypothesis implies that the amino acid sequence of a protein is co-linear with the nucleotide sequence in the corresponding gene (Sarabhai, Stretton, Brenner, and Bolle, 1964; Yanofsky, Carlton, Guest, Helinski, and Henning, 1964). The triplet 'code letters' which probably code for each amino acid on the mRNA have been the subject of much investigation (Nirenberg, Jones, Leder, Clark, Sly, and Pestka, 1963). A current summary of the proposed RNA code words is given in Table III. It can be

\section{TABLE III}

SUMMARY OF RNA CODE WORDS (Nirenberg et al., 1963)

\begin{tabular}{|c|c|c|c|c|}
\hline Amino Acid & & RNA Code & Words* & \\
\hline $\begin{array}{l}\text { Alanine } \\
\text { Arginine } \\
\text { Asparagine } \\
\text { Aspartic acid } \\
\text { Cysteine } \\
\text { Glutamic acid } \\
\text { Glutamine } \\
\text { Glycine } \\
\text { Histidine } \\
\text { Isoleucine } \\
\text { Leucine } \\
\text { Lysine } \\
\text { Methionine } \\
\text { Phenylalanine } \\
\text { Proline } \\
\text { Serine } \\
\text { Threonine } \\
\text { Tryptophan } \\
\text { Tyrosine } \\
\text { Valine }\end{array}$ & $\begin{array}{l}\text { CCG } \\
\text { CGC } \\
\text { ACA } \\
\text { GUA } \\
\text { UUG } \\
\text { GAA } \\
\text { AAC } \\
\text { UGG } \\
\text { ACC } \\
\text { UAU } \\
\text { UUG } \\
\text { AAA } \\
\text { UGA } \\
\text { UUU } \\
\text { CCC } \\
\text { UCU } \\
\text { CAC } \\
\text { GGU } \\
\text { AUU } \\
\text { UGU }\end{array}$ & $\begin{array}{l}\text { UCG } † \\
\text { AGA } \\
\text { AUA } \\
\text { GCA } \dagger \\
\text { GAU† } \dagger \\
\text { AGA } \\
\text { AGG } \\
\text { ACU } \dagger \\
\text { UAA } \\
\text { UUC } \\
\text { AAU } \\
\text { CUU } \\
\text { CCU } \\
\text { UCC } \\
\text { CAA } \\
\text { UGA } \dagger\end{array}$ & 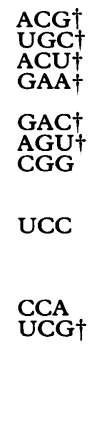 & $\begin{array}{l}\text { CCG } \\
\text { ACG }\end{array}$ \\
\hline
\end{tabular}

* Arbitrary nucleotide sequence.

$\dagger$ Probable.

seen that more than one 'code word' has been proposed for some amino acids, in keeping with the suggested 'degeneracy' of the genetic code. It has been postulated that a point mutation is a change of a single nucleotide base in a three-letter code word and all the known amino acid substitutions in the abnormal haemoglobins are consistent with this hypothesis. For example, the two substitutions at position 6 of the $\beta^{\mathrm{A}}$-chain, glutamic acid $\rightarrow$ valine in $\mathrm{Hb}-\mathrm{S}$ and glutamic acid $\rightarrow$ lysine in $\mathrm{Hb}-\mathrm{C} \stackrel{\overbrace{}}{\frac{\Phi}{9}}$ fit in as shown below.

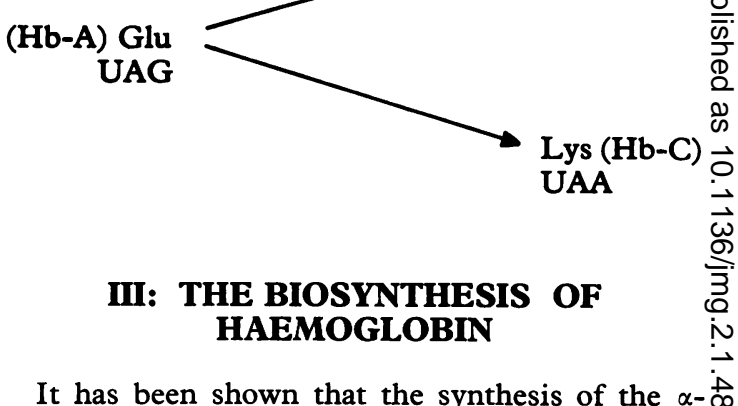
and $\beta$-chains of $\mathrm{Hb}-\mathrm{A}$ are controlled by separate, 을 unlinked genes, and that in individuals carryingboth abnormal $\alpha$-chains and abnormal $\beta$-chains 3 four types of haemoglobins are found (Fig. 17). It $\frac{0}{3}$ can thus be assumed that the $\alpha$-chains are syn- $\mathcal{\partial}$ thesized separately from the $\beta$-chains. From the $\vec{\varphi}$ work of Bishop, Leahy, and Schweet (I960) and $O$ Dintzis (196r), it is known that synthesis of the polypeptide chains begins at their $\mathrm{N}$-terminals and the amino acids are added sequentially until the chains are completed. The haem groups are separately synthesized (see Rimington, 1959). $\frac{\mathrm{Q}}{\mathrm{Q}}$ Following synthesis, the polypeptide chains and $\stackrel{\varrho}{\Rightarrow}$ haem groups are assembled into the tetramer haemo-음 globins found in the red cell. At present, it is not known at which stage the haem groups are attached, but there is some knowledge of the order in which the polypeptide chains assemble. This comes from recent experiments on the dissociation of haemoglobin.

\section{The Dissociation of Haemoglobin}

It is well known that haemoglobin dissociates at acid $p \mathrm{H}$ and that in mixtures of suitable haemo- $\frac{}{5}$ globins exchange of chains takes place with the formation of hybrid haemoglobins. A good illustration is the formation of hybrids between human $N$ and canine haemoglobins (Robinson and Itano, 1960; Huehns et al., 1962a) (Fig. 12). The composition of the hybrids formed is given by the following $\omega$ over-all reaction:

$$
\alpha_{2}^{\mathbf{A}} \beta_{2}^{\mathbf{A}}+\alpha_{2}^{\mathrm{Can}} \beta_{2}^{\mathrm{Can}} \rightarrow \alpha_{2}^{\mathbf{A}} \beta_{2}^{\mathrm{Can}}+\alpha_{2}^{\mathrm{Can}} \beta_{2}^{\mathbf{A}} .
$$

Some of each of the parent species are also reformed. $\stackrel{\mathbb{P}}{\rightarrow}$ Although this result may be explained most readily 0 by postulating that each haemoglobin dissociates $\overrightarrow{0}$ into $\alpha_{2}$ and $\beta_{2}$ subunits and that these subunits then exchange, there are a number of observations $\mathbb{\Phi}$ 
that do not fit into this scheme. For example, it is known that both $\mathrm{Hb}-\mathrm{A}$ and canine haemoglobin dissociate into subunits immediately the $p H$ is lowered below $5 \cdot 0$. Yet it is necessary to hold the two haemoglobins at these $\mathrm{pH}$ values for many hours before exchange of subunits and formation of hybrids occur (Labie, Rosa, Dreyfus, and Shapira, 1962; Huehns, Shooter, and Beaven, I964d). Clearly if the subunits were $\alpha_{2}$ and $\beta_{2}$, there would be no reason for this delay in exchange. However, it can be accounted for if it is assumed that the initial rapid dissociation is into $\alpha \beta$ subunits, that these further dissociate at a slower rate into single $\alpha$ - and $\beta$-chains, and that the exchange takes place at the single chain level (Vinograd and Hutchinson, 1960). Supporting evidence for this mechanism comes from the finding that the isolated $\alpha^{\mathrm{A}}$-chain subunits from $\mathrm{Hb}-\mathrm{A}$ do, in fact, exist in solution as stable monomers rather than $\alpha_{2}^{A}$ dimers (Huehns et al., 196Ib). The question then arises as to why only like $\alpha \beta$ subunits unite, since species with unlike $\alpha$ - or unlike $\beta$-chains have not been observed. Moreover, attempts to produce such species by a number of different experimental approaches have failed (Huehns and Shooter, I964b). For example, globins with the structure $\alpha \beta$ have been prepared which reform tetramer haemoglobins on the addition of haem (Winterhalter and Huehns, 1964). When a mixture of globin $\mathrm{C}$ is mixed with globin $\mathrm{A}$ and haem added, three haemoglobin species could form, as follows.

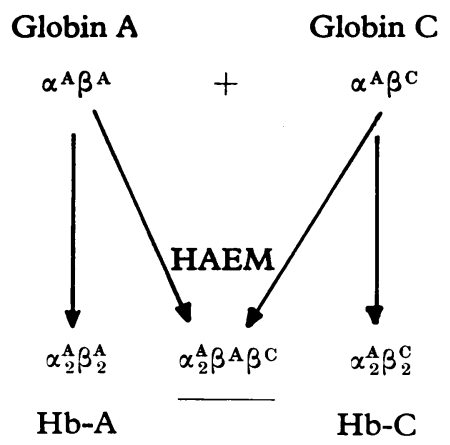

However, on starch gel analysis of the reacted product, only $\mathrm{Hb}-\mathrm{A}$ and $\mathrm{Hb}-\mathrm{C}$ were detected. What then prevents an $\alpha^{\mathrm{A}} \beta^{\mathrm{A}}$ subunit combining with an $\alpha^{\mathrm{A}} \beta^{\mathrm{C}}$ subunit to form the hybrid $\alpha_{2}^{\mathrm{A}} \beta^{\mathrm{A}} \beta^{\mathrm{C}}$ ? One explanation (Vinograd and Hutchinson, 1960) is that recombination is specific and that only like $\alpha \beta$ subunits can combine with one another. This explanation seems unlikely, since it is very difficult to see how a single amino acid substitution on the surface of the coiled polypeptide chain could prevent association of an $\alpha^{\mathrm{A}} \beta^{\mathrm{A}}$ subunit with an $\alpha^{\mathrm{A}} \beta^{\mathrm{C}}$ subunit. Moreover, all the single amino acid substitutions in the many abnormal haemoglobins would have to obey the same restriction. Recently Guidotti, Konigsberg, and Craig (1963) have put forward a plausible explanation. They suggest that such mixed hybrids with unlike $\alpha$ - and unlike $\beta$-chains do form, and that there is no specificity in the recombination of $\alpha \beta$ subunits. They argue that the reason why these species are not observed is because even at neutral $p \mathrm{H}$ haemoglobin is dissociated (Drabkin and Wise, 1962; Huehns, 1962; Huehns, Beaven, and Stevens, 1964f) and is in equilibrium with $\alpha \beta$ dimers, i.e. $\alpha_{2} \beta_{2} \rightleftharpoons 2 \alpha \beta$ (Huehns, 1962). It follows that in any separation process the species $\alpha_{2}^{A} \beta^{A} \beta^{C}$, for example, will dissociate into $\alpha^{\mathrm{A}} \beta^{\mathrm{A}}$ and $\alpha^{\mathrm{A}} \beta^{\mathrm{C}}$ subunits and that these will then predominantly form the species $\alpha_{2}^{\mathbf{A}} \beta_{2}^{\mathbf{A}}$ and $\alpha_{2}^{\mathrm{A}} \beta_{2}^{\mathrm{C}}$. This hypothesis eliminates the need to postulate steric factors to prevent unlike $\alpha \beta$ subunits combining.

There are two haemoglobin species in which unlike chains occur, Hb-F $\left(\alpha_{2}^{\mathbf{A}} \gamma^{\mathrm{F}} \gamma^{\mathrm{AcF}}\right)$ (Schroeder et al., I962) and $\mathrm{Hb}-\mathrm{A}_{\mathrm{Ic}}\left(\alpha_{2}^{\mathrm{A}} \beta^{\mathrm{A}} \beta_{\mathrm{X}}\right)$ (Holmquist and Schroeder, 1964). In $\mathrm{Hb}-\mathrm{F}_{\mathrm{I}}$, the $\mathrm{N}$-terminal of one of the $\gamma$-chains is blocked by an acetyl group, while in $\mathrm{Hb}-\mathrm{A}_{\text {Ic }}$ the $\mathrm{N}$-terminal of one of the $\beta$ chains is blocked by an unidentified grouping. If the above explanations prove correct, then some special explanation for the ability to isolate these two mixed species must be found and this is discussed elsewhere (Huehns and Shooter, 1964b).

It does not necessarily follow that the assembly of the haemoglobin molecule will maintain the same course as its dissociation, but the properties of the isolated subunits, in particular, the stability of the monomer $\alpha^{\mathrm{A}}$-chain subunit, as well as the close contact between $\alpha$ - and $\beta$-chain subunits demonstrated by the $x$-ray work, make this the most plausible mechanism.

Since, in the normal adult, equal numbers of $\alpha$ and $\beta$-chains are produced, there is presumably a mechanism adjusting the rate of synthesis of one of the chains to that of the other. In deficiency of $\alpha$-chain synthesis- $\alpha$-thalassaemia- $-\mathrm{Hb}-\beta_{4}$ is found in quantity (see later), while in the severest deficiencies of $\beta$-chain synthesis- $\beta$-thalassaemia majoronly trace amounts of free $\alpha$-chains are found (Fessas and Loukopoulos, 1964). These findings have led to the suggestion that completed $\beta$-chains are necessary for the free release of $\alpha$-chains from their site of synthesis (Huehns and Shooter, 1962). In this way, the effective rate of $\alpha$-chain synthesis 
is adjusted to that of $\beta$-chains. In release of the completed chains, an $\alpha \beta$ subunit is formed, and finally two of these combine to form the tetramer haemoglobin molecules found in the red cell. The haem group is separately synthesized. It appears that the rate of haem synthesis is linked to that of globin synthesis by a feedback mechanism, any excess haem formed depressing the activity of $\delta$ amino-laevulic acid ( $\delta$-ALA) synthetase (Lascelles, 1960; Burnham and Lascelles, 1963).

It is not clear yet at which stage the haem group combines with the globin chains. The finding that there is a small amount of free globin in the red cells (Winterhalter and Huehns, 1963) leads to the speculation that the $\alpha \beta$ intermediate postulated above is globin (which is known to have the structure $\alpha \beta$ ) and that the addition of haem brings about the association of two $\alpha \beta$ subunits.

\section{IV: CLINICAL FEATURES OF ABNORMALITIES IN HAEMOGLOBIN SYNTHESIS}

The various ways in which abnormalities of protein synthesis might cause disease are well demonstrated by the abnormalities in haemoglobin synthesis. It can be envisaged that disease can be caused in several ways:

(i) the production of an abnormal protein molecule-the haemoglobinopathies;

(ii) the reduction in the amount of normal protein synthesized-the thalassaemias;

(iii) developmental anomalies-the persistence of foetal haemoglobins.

\section{The Haemoglobinopathies}

The haemoglobinopathies can be divided into several groups. Clinically, the most important of these is sickle cell disease and its variants, and this disease process is brought about by a specific new property of the protein consequent to the amino acid substitution. The haemoglobin $\mathbf{M}$ diseases form another group, in which the ability to carry oxygen is due to the in vivo formation of abnormal methaemoglobins. Other haemoglobinopathies are characterized by the presence of haemolytic anaemia associated with the presence of unstable abnormal haemoglobins in the heterozygous state. Finally, there are the mild diseases that occur when some abnormal haemoglobin, such as $\mathrm{Hb}-\mathrm{C}, \mathrm{Hb}-\mathrm{D}$, or $\mathrm{Hb}-\mathrm{E}$, is found in the homozygous state. (i) Sickle Cell Disease. The clinical features of this disease and the milder syndromes caused by the $\underset{\mathbb{T}}{+}$ interaction with other haemoglobin syndromes are already well described (Wintrobe, 196I). However, in recent years, the way in which the substitution? of a single amino acid (glutamic to valine) in each of $\overline{=}$ the $\beta$-chains leads to this severe disease has now $\frac{\bar{N}}{\partial}$

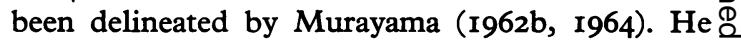
has suggested that in $\mathrm{Hb}-\mathrm{S}$ the substitution of a glutamic residue at position 6 by a valyl residue leads to the formation of a ring of amino acids at the $?$ $\mathrm{N}$-terminus of each of the $\beta$-chains, the $\mathrm{N}$-terminal $\vec{\omega}$ valine forming a non-covalent (hydrophobic) bond o with the genetically introduced valine at position $6 . \bar{\exists}$ These cyclic structures on each of the $\beta$-chains are situated in such a position that when the haemo- globin molecule is reduced, they interlock with the $\alpha$-chains of the next haemoglobin molecule, forming 0 long chains. These aggregates are presumably birefringent spindle-shaped bodies, $1-15 \mu$ in $\bar{z}$ length, the so-called tactoids (Sherman, I940), ฏ which characteristically occur in sickle cells. The $\frac{\rho}{\partial}$ fact that the in vitro and in vivo formation of $\vec{\theta}$ sickle cells depends on the oxygen tension is well $\stackrel{\circ}{\circ}$ known (Hahn and Gillespie, 1927; Lange, Minnich, and Moore, I95I; Harris, Brewster, Ham, and Castle, 1956) and fits in well with Murayama's ideas. Muirhead and Perutz (1963) have shown that the $\beta$-chains of reduced haemoglobin are $7 \AA \frac{\AA}{\varnothing}$ further apart than in the oxygenated form, while $\unrhd$ the $\alpha$-chains show no such change in position. $\overrightarrow{\overrightarrow{0}}$ Clearly, if a 'key' on each of the $\beta$-chains can fit 3 into the $\alpha$-chains of the next molecule in the reduced state, this fit will not be possible in the oxygenated state when the $\beta$-chains in the molecule are closer together.

The sickling of the erythrocyte causes two sig- $\frac{}{3}$ nificant changes. First, it causes an increase in the mechanical fragility (Diggs and Bibb, 1939; Lange $O$ et al., I95I; Harris et al., 1956) and this leads to the random destruction of a proportion of red cells $\frac{\text { 의 }}{2}$ before the process is reversed by re-oxygenation of $D$ the haemoglobin in the lungs. The second change is an increase in the viscosity of the blood (Ham N and Castle, 1940; Harris et al., 1956), which, in certain circumstances, leads to stasis of the red $N$ cells, with consequent further loss of oxygen and $\underset{\omega}{N}$ increased sickling. The sickled cells then form thrombi which give rise to the well-known throm- 0 botic symptoms of the disease. These trapped red $\stackrel{D}{D}$ cells are then lysed, adding further haemolysis to $\stackrel{\oplus}{+}$ the random destruction of red cells mentioned $T$ above. The lessened severity of the different variants of sickle cell disease is well known and appears to be due to the relative resistance to sick- 
ling of these cells when compared with sickle cell anaemia cells (Griggs and Harris, 1955). It appears that lower oxygen tensions are necessary for the production of sickling in these cells, as well as for the increase in mechanical fragility and blood viscosity. In sickle cell trait, sickling does not commence until the oxygen tension drops to less than Io $\mathrm{mm}$. $\mathrm{Hg}$, which is lower than that normally found in the tissues. This finding is, of course, in agreement with the clinical observation that the trait condition only leads to pathology under special circumstances (Levin, 1958). In Hb-SC disease and sickle-cell thalassaemia, the increase in mechanical fragility of the red cells begins at an oxygen tension of $50 \mathrm{~mm}$. $\mathrm{Hg}$. These two diseases are, therefore, almost as severe as sickle cell disease. In sickle-cell persistent $\mathrm{Hb}-\mathrm{F}$ disease, the increase in mechanical fragility does not begin until the oxygen tension drops to below $30 \mathrm{~mm}$. $\mathrm{Hg}$, and the clinical condition is relatively mild.

In this connexion, it is of interest that in vitro sickling of erythrocytes has been reported in association with other abnormal haemoglobins besides $\mathrm{Hb}-\mathrm{S}$, namely, $\mathrm{Hb}-\gamma_{4}$ (Lie Injo Luan Eng, 196r), Hb-I (Atwater, Schwartz, Erslev, Montgomery, and Tocantins, 1960a) and $\mathrm{Hb}^{-\mathrm{C}_{\mathrm{George}}}$ tow (Pierce, Rath, and McCoy, 1963). Murayama (1964) has examined the sickling phenomena in red cells from the subject with $\mathrm{Hb}-\mathrm{C}_{\mathrm{Georgetown}}$ and found that the mechanism differs from that causing sickling in red cells containing $\mathrm{Hb}-\mathrm{S}$.

(ii) Haemoglobin $M$ Disease. In this group of haemoglobinopathies, the ability to carry oxygen is impaired due to the formation of an unusually stable methaemoglobin derivative. This leads in turn to cyanosis which is present at birth or commences shortly afterwards, but is not associated with the presence of any serious physical disability. The lack of disability distinguishes 'biochemical' methaemoglobinaemia from 'physiological' methaemoglobinaemia (due to congenital heart disease). The biochemical methaemoglobinaemias fall into two groups: those due to deficiency in the methaemoglobin reductase enzyme system (Gibson, 1948; Scott, 1960; Townes and Morrison, 1962) and those due to abnormal haemoglobins; the latter are the $\mathrm{Hb}-\mathrm{M}$ diseases.

Hörlein and Weber (1948, I95I) were the first to show that primary abnormality in their cases of methaemoglobinaemia lay in the globin part of haemoglobin, while the haem group was normal. The disease is characterized by the appearance of cyanosis at birth or shortly afterwards, without any of the disabilities associated with cyanosis due

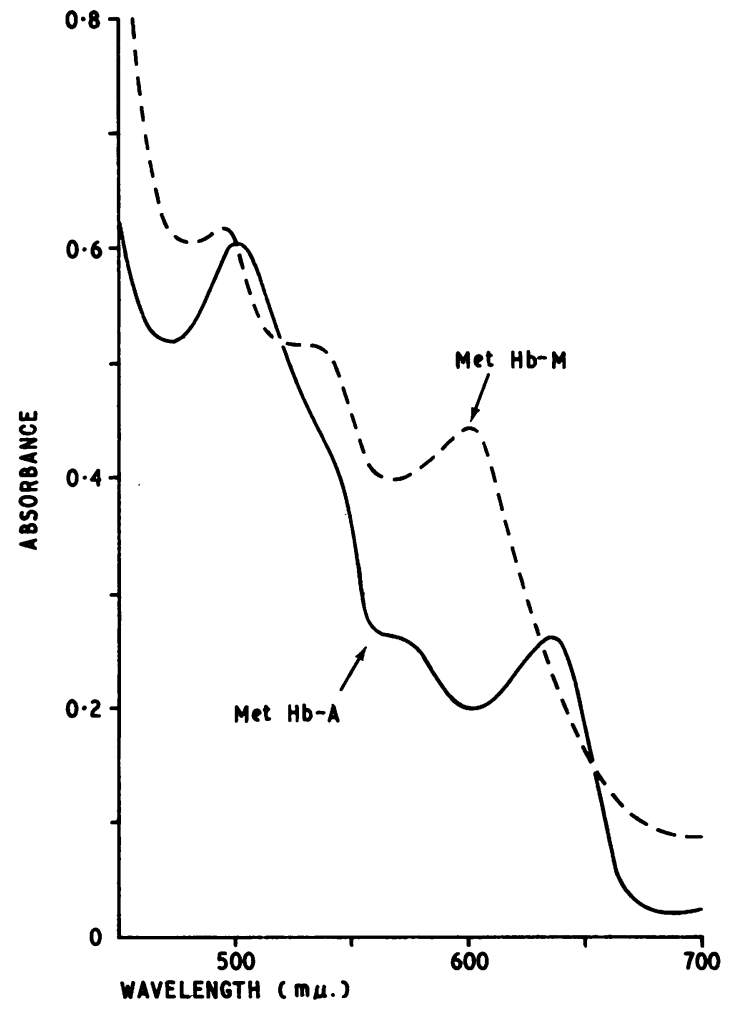

FIG. 20. Absorption spectra at $p H \quad 7.0$ of methaemoglobin A, compared with methaemoglobin $M_{\text {saskatoon (modified from Gerald }}$ and George (1959) with permission).

to congenital heart disease. The prognosis is good. The disease can be distinguished from the other 'biochemical' methaemoglobinaemias due to enzyme abnormalities by definitive differences in the spectrum of the acid methaemoglobin derivative and by the presence of the abnormal haemoglobin. The spectral difference seen is in the region of $550-650 \mathrm{~m} \mu$ and consists of a shift of the normal absorption maximum 632 to a lower wavelength at approximately $600 \mathrm{~m} \mu$ (Fig. 20). The degree of these changes varies in the different types of $\mathrm{Hb}-\mathrm{M}$ described. Minor changes in the spectrum or the presence of $\mathrm{Hb}-\mathrm{M}$ in whole haemolysates may only lead to filling in of the normal minimum at $600 \mathrm{~m} \mu$ The electrophoretic demonstration of the abnormal haemoglobin may be difficult using conventional paper or starch gel electrophoresis, and analysis of the methaemoglobin derivatives at $p H \quad 7 \cdot 0$ is recommended (Gerald, 1958).

A large number of patients with $\mathrm{Hb}-\mathrm{M}$ disease have been described and are reviewed in detail 
by Jaffe and Heller (1964). The various haemoglobins $M$ which have been chemically studied are listed in Table II, and it can be seen that several haemoglobins originally described separately are identical.

The stability of the methaemoglobin form and the spectral abnormality can readily be explained on the basis of the amino acid substitution found in these haemoglobins (Gerald and Efron, 1961; Baglioni, I963a). In two of the $\mathrm{Hb}-\mathrm{Ms}$, the substitution is at the histidine residue distal to the haem group which, as has already been noted, is bonded in Hb-A to a water molecule on the sixth co-ordination position of the iron atom. In $\mathrm{Hb}-$ $M_{\text {Boston, the histidine in the } \alpha \text {-chains is replaced }}$ by tyrosine, as is the corresponding histidine (position 63) in the $\beta$-chain in Hb-M saskatoon. The reason why the methaemoglobin form of these two haemoglobins resists reduction to the physiologically useful form of haemoglobin is explained by this substitution, the tyrosine anion being in a position to form a stable complex with the ferric iron of the haem group. Just how critical the location of this residue for the formation of such a complex is, is illustrated by the substitution in the variant $\mathrm{Hb}$-Norfolk. Here, the next amino acid to the distal histidine residue in the $\alpha^{\mathrm{A}}$-chain is involved, an aspartic acid residue replacing the glycine (position 5I), but no stable methaemoglobin results. This section of the polypeptide chain is an $\alpha$-helix and therefore the glycine residue points in a direction which is at an angle of approximately $100^{\circ}$ to the direction of the histidine residue. The side chain of the fourth residue from the distal histidine, on the other hand, points in roughly the same direction as the histidine, and a substitution here, glutamic acid replacing valine (position 367 ), produces a stable methaemoglobin, namely $\mathrm{Hb}-\mathrm{M}_{\mathrm{Mil} \text { wa u kee } 1 .}$.

In $\mathrm{Hb}-\mathrm{M}_{\mathrm{Iw} \text { ate }}$, the so-called proximal histidine at position 87 in the $\alpha$-chain is replaced by a tyrosine residue (Miyaji, Iuchi, Shibata, Takeda, and Tamura, 1963a; Jones, Coleman, and Heller, 1964). In normal haemoglobin, this histidine is linked to the iron of the haem group. Presumably, in $\mathrm{Hb}-\mathrm{M}_{\mathrm{Iw} \text { ate, }}$, the haem group is held in position by co-ordination to the histidine at position 58 on the opposite side of the haem group, and the new tyrosine residue forms a similar, stable complex with the ferric iron as the tyrosine at position 58 in $\mathrm{Hb}-\mathrm{M}_{\mathrm{Boston}}$, leading to the usual spectral abnormality.

Another haemoglobin variant that may be related to the haemoglobins $M$ has been reported (Reissmann, Ruth, and Nomura, I96I). This haemo- globin causes cyanosis due to a lowered oxygen affinity and impaired haem-haem interactions.

Some of the unstable haemoglobins referred. to in the next section have their abnormality in? the same region of the polypeptide chain, near the haem group. These haemoglobins are associated with haemolytic disease and more rapids methaemoglobin formation in the red cell. Some of them also show differences in the absorptiono spectrum of the acid methaemoglobin derivative in the region 550-650 $\mathrm{m} \mu$, similar to those seen in the Hb-Ms. Conversely, it might be expected $\vec{\omega}$ that some of the M-type haemoglobins woulde show some instability with consequent haemolytic $\overline{3}$ disease. A shortened ${ }^{51} \mathrm{Cr}$-labelled red cell surviva and increase in reticulocytes have been reportedin association with $\mathrm{Hb}-\mathrm{M}_{\text {Chicago ( Sas katoon }}$ id $_{\infty}$ (Josephson et al., 1962). In several other instances ao raised reticulocyte count has been reported (Heck? and Wolf, 1958) $(3.3 \%), \mathrm{Hb}-\mathrm{M}_{\text {Milwa uee } 1}(2-3 \%)$ (Pisciotta, Ebbe, and Hinz, 1959), Hb-M Milw a u kee (4\%) (Pisciotta et al., 1959). There was definitive? haemolysis in the patient who carried both $\mathrm{Hb}-\mathrm{C}-\vec{C}$ trait and $\mathrm{Hb}-\mathrm{M}_{\mathrm{Milw}}$ a uee 2, whereas in $\mathrm{Hb}-\mathrm{C}$ traito the reticulocyte count was normal. It thus appears that some haemolysis is present in a number of patients with $\mathrm{Hb}-\mathrm{M}$ disease.

(iii) The 'Unstable Haemoglobin' Diseases. $\stackrel{\mathscr{D}}{\circ}$ A number of abnormal haemoglobins has recently $\overrightarrow{{ }_{0}}$ been discovered in which an amino acid substitution 3 produces a molecule that is less stable than the normal form, and a number of haemoglobinopathieș. due to such haemoglobins have now been described

HaEmoglobin ZüRICH Disease. This is a familiaP haemoglobinopathy (Frick, Hitzig, and Betke 1962; Bachmann and Marti, 1962) characterizedo by severe haemolytic crises precipitated by oraR sulphonamides. During the crises, the haemo-음 globin drops to 3-6 g. per $100 \mathrm{ml}$. with a high $(40 \%)$ reticulocytosis. The red cells in the stained? smear show marked anisocytosis and fragmentation with the presence of many large inclusion bodies? thought to be precipitated haemoglobin. Durings the quiescent stage of the disease there is veryte little anaemia, but haemolysis is still present, as, shown by a raised reticulocyte count and red celb survival.

The abnormal haemoglobin is easily detected by electrophoresis at $p \mathrm{H} 8.6$, migrating on papero or starch gel with $\mathrm{Hb}-\mathrm{S}$. The amino acid substitution is in the $\beta$-chains, the so-called distap histidine at position 63 being replaced by arginin $\varepsilon_{\square}$ 
(Muller and Kingma, 196I). The rate of methaemoglobin formation in the red cells incubated in vitro at $37^{\circ} \mathrm{C}$. is significantly increased when compared to normal controls. No spectral abnormalities of this haemoglobin have been reported.

HaEmoglobin Ube-I Disease. This disease has been reported in one person from Japan (Shibata, Iuchi, Miyaji, Ueda, and Takeda, I963). His parents did not have any abnormality. It is a severe haemolytic disorder associated with Heinz body formation. The condition of the patient was considerably improved by splenectomy.

The abnormal haemoglobin is easily separated by electrophoresis, amounting to approximately $10 \%$ of total haemoglobin. It migrates between $\mathrm{Hb}-\mathrm{S}$ and $\mathrm{Hb}-\mathrm{C}$. Structural studies indicate that this abnormality is in the insoluble tryptic peptides (X-XII) of the $\beta$-chain with loss of reactivity of the sulphydryl at position 92 .

Haemoglobin Seattre Disease. This disease is a mild non-spherocytic haemolytic anaemia with a haemoglobin of approximately II g. $\%$ and $2-4 \%$ reticulocytes (Huehns, E. R., Hartmann, J., Hecht, F., and Motulsky, A. G., unpublished). In the affected family, three heterozygous carriers of the abnormal haemoglobin in two generations have the disease, making it likely that the haemoglobin is directly related to the disease.

The haemoglobin is distinctive in its electrophoretic properties. It does not separate from $\mathrm{Hb}-\mathrm{A}$ by paper or starch block electrophoresis in the usual barbiturate buffers at $p \mathrm{H} 8 \cdot 6$, though the amount of $\mathrm{Hb}-\mathrm{A}_{3}$ appears somewhat increased. It is also not separable on starch gel electrophoresis in the tris-citrate/borate discontinuous system of Poulik (1957). Thus, this abnormal haemoglobin cannot be detected by the usual electrophoretic systems. Hb-Seattle can, however, be easily separated by starch gel electrophoresis, using a sodium phosphate buffer at $p \mathrm{H} 7 \cdot 4$ or a trisE.D.T.A./borate buffer at $p \mathrm{H} 8 \cdot 6$. It amounts to $40 \%$ of total haemoglobin in the red cells. The abnormal haemoglobin is less stable than $\mathrm{Hb}-\mathrm{A}$ to heat denaturation.

Though there are no inclusion bodies or methaemoglobin in fresh red cells, both appear more rapidly than in normal cells on in vitro incubation. The absorption spectrum of the acid methaemoglobin derivative of $\mathrm{Hb}$-Seattle is slightly abnormal in the region of 550-650 $\mathrm{m} \mu$, showing some filling in of the normal minimum at $600 \mathrm{~m} \mu$. Structural studies indicate that the abnormality is in the $\beta$-chains, an alanine residue being replaced by glutamic acid at position 70 or 76 in peptide $\beta$ TpIX.

Haemoglobin St. Mary's Disease. Hb-St. Mary's disease (Buchanan, A., Barkhan, P., Crome, P. E., Mollison, P. L., and Huehns, E. R., unpublished) is a well-compensated haemolytic disease with a shortened red cell life-span and $10 \%$ reticulocytes. The patient had a number of haemolytic crises with moderately severe anaemia. The disease is distinguished from the other haemolytic anaemias due to abnormal haemoglobins in that the abnormal haemoglobin cannot be resolved by paper or starch block electrophoresis in barbiturate buffer, $p \mathrm{H} 8 \cdot 6$, or by starch gel electrophoresis in tris-citrate borate buffer, $p \mathrm{H} 8.6$, or phosphate buffer, pH 7·4. However, Hb-St. Mary's can be separated by starch gel electrophoresis in a

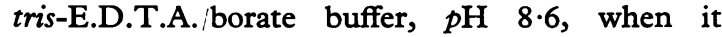
migrates close to $\mathrm{Hb}-\mathrm{S}$. It amounts to $\mathrm{II} \%$ of total haemoglobin. Structural studies of the isolated haemoglobin indicate that the abnormality is probably in the insoluble (core) tryptic peptides of the $\beta$-chains. The possibility that the abnormality is close to the haem group is suggested by the finding that the absorption spectrum of the acid methaemoglobin derivative is abnormal in the region $550-650 \mathrm{~m} \mu$. The haemoglobin is unstable and is more readily denatured by heat than is normal haemoglobin (Fig. 2I).

Both $\mathrm{Hb}-\mathrm{Seattle}$ and $\mathrm{Hb}-\mathrm{St}$. Mary's are haemoglobins which are more unstable in vitro than $\mathrm{Hb}-\mathrm{A}$, and this instability can be shown in various ways, one of which is heat denaturation. However, studies by Sephadex chromatography show that the instability of the molecule leads to both increased dissociation of the molecule as well as polymer formation at neutral $\mathrm{pH}^{*}$. This tendency is shown to a significantly greater degree by $\mathrm{Hb}-\mathrm{St}$. Mary's than Hb-Seattle, which is consistent with the in vivo pathological effect of the two haemoglobins. It is also of interest that $\mathrm{Hb}-\alpha^{\mathrm{A}}$ is found in the haemolysate containing these haemoglobins, indicating that the $\beta$-chains-the abnormal chains - of these haemoglobins are more unstable than the complementary normal $\alpha$-chains.

Haemoglobin Köln Disease. Pribilla (1962) has described a family in which some members have a mild haemolytic disease associated with an abnormal haemoglobin and the formation of

\footnotetext{
* In vitro polymer formation has been noted in one human haemoglobin without any associated disease in the heterozygous or homozygous states (Tondo, Salzano, and Rucknagel, 1963).
} 


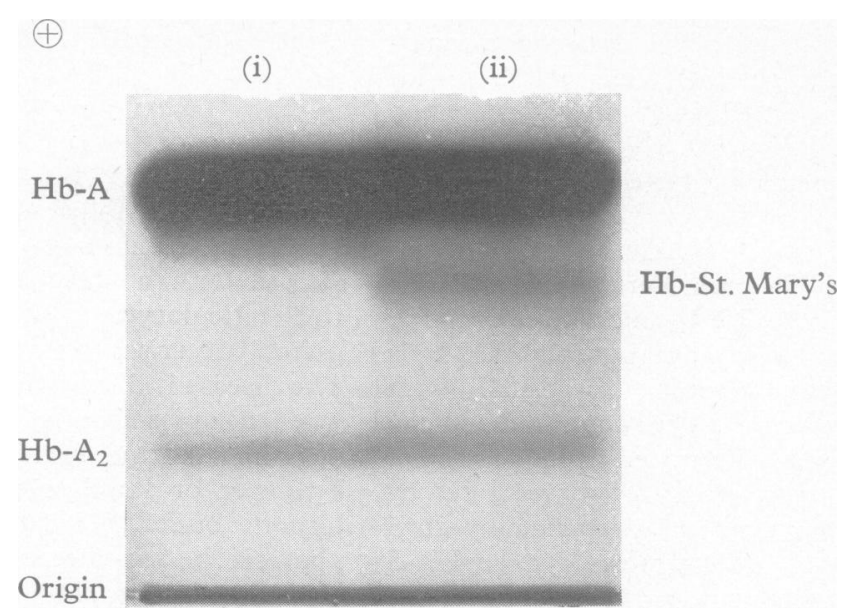

FrG. 21. Starch gel electrophoresis tris-E.D.T.A.-borate buffer $p H$ 8.6 of haemolysate containing $\mathrm{Hb}-\mathrm{A}, \mathrm{Hb}-\mathrm{A}_{2}$, and the unstable haemoglobin Hb-St. Mary's: (i) after incubation at $70^{\circ} \mathrm{C}$. for I minute, note absence of unstable haemoglobin; (ii) untreated control.

Heinz bodies. The abnormal haemoglobin amounted to $5 \%$ of total haemoglobin and on electrophoresis it migrated close to $\mathrm{Hb}-\mathrm{S}$. More recently, a second family, with the same abnormal haemoglobin, has been described in Scotland (Hutchison, Pinkerton, Waters, Douglas, Lehmann, and Beale, 1964). In this family, the haemoglobin abnormality was found in three generations, and each affected person showed haemolytic anaemia with Heinz body formation. There was some improvement of the disease on splenectomy. Structural studies show that the haemoglobin has abnormal $\beta$-chains with the abnormality in the insoluble (core) tryptic peptides. As with $\mathrm{Hb}-S e a t t l e$ and $\mathrm{Hb}$-St. Mary's, free $\alpha^{\mathrm{A}}$-chain haemoglobin was found in the haemolysate (Huehns, E. R., unpublished). The electrophoretic properties of $\mathrm{Hb}$ Köln distinguish it from $\mathrm{Hb}-\mathrm{St}$. Mary's and $\mathrm{Hb}-$ Seattle.

The 'Heat-Unstable Haemoglobin' Diseases. Two families with this type of unstable haemoglobin have been described (Grimes and Meisler, 1962; Grimes, Meisler, and Dacie, 1964; Dacie, Grimes, Meisler, Steingold, Hemsted, Beaven, and White, 1964). The first patient (Grimes et al., 1964) had a severe haemolytic anaemia with a haemoglobin of 6-8 g. per $100 \mathrm{ml}$., and $22-47 \%$ reticulocytes. Following splenectomy there was some clinical improvement, and the red cells were found to contain many Heinz bodies. No abnormal haemoglobin could be detected by electrophoresis on paper or starch gel of fresho haemolysates. However, a proportion (approximately $35 \%$ ) of the haemoglobin was relativelyo unstable and denatured readily on heating to음

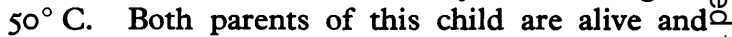
well and have normal blood counts.

In the second family (Dacie et al., 1964) a mild 3 haemolytic anaemia was found in four generations? of the same family. The haemoglobin values? ranged from $10-14 \mathrm{~g}$. per $100 \mathrm{ml}$. with reticulocyte counts of $10 \%$ Heinz bodies were found onlyo in the red cells of one patient who had previously? been splenectomized. However, Heinz bodies. could be detected in the red cells of the othero affected individuals after in vitro incubation of the red cells.

On heating the haemoglobin solution to $50^{\circ} \mathrm{C}$. for $>$ one hour, a precipitate of haemoglobin developed, indicating the presence of some heat-unstable N haemoglobin. On paper electrophoresis, onlysome trailing pigment behind $\mathrm{Hb}-\mathrm{A}$ was seen. On $\mathrm{O}$ starch gel electrophoresis in a tris-citrate/borate $\mathcal{\omega}^{-}$ buffer system at $p H$ 8.6, three abnormal zones could be seen besides $\mathrm{Hb}-\mathrm{A}, \mathrm{Hb}-\mathrm{A}_{2}$ and $\mathrm{Hb}-\mathrm{A}_{3} \cdot \mathrm{O}$ Two of these migrated between $\mathrm{Hb}-\mathrm{A}$ and $\mathrm{Hb}-\mathrm{A}_{2} \stackrel{\bar{\Phi}}{\overparen{D}}$ and one just slower than $\mathrm{Hb}-\mathrm{A}_{2}$. The total amount? of abnormal pigment was approximately $15 \%$. The three abnormal zones seen on starch gel우

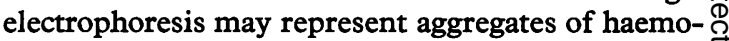
globin with different molecular weights being $\underset{\perp}{\mathbb{Q}}$ 
retarded to differing extents by the pores in the gel. At $p \mathrm{H} 6.9$, in phosphate buffer, a small zone migrating more rapidly toward the cathode was seen. This extra zone was not seen after the addition of cyanide. Further study shows that this largely consists of free haem (G. H. Beaven, personal communication), and this finding may indicate that the haem-protein linkage in this haemoglobin is less stable than in normal haemoglobin.

There are a number of other reports of haemolytic anaemias in association with inclusion bodies (Lange and Akeroyd, 1958; Schmid, Brecher, and Clemens, I959; Scott, Haut, Cartwright, and Wintrobe, 1960), and it appears likely that at least some of these will eventually be shown to be associated with an abnormal haemoglobin.

From the diseases described in this section, it is clear that a proportion of the non-spherocytic haemolytic anaemias is due to the presence of abnormal haemoglobins in the heterozygous state and that the haemolytic process is directly related to the instability of the haemoglobin. This direct relation between the presence of an abnormal unstable haemoglobin and disease seems certain in those studies where several members of a family in more than one generation are affected. In other reports, where only an isolated case has been studied, the relation is not at all clear. In these instances, the abnormal haemoglobin may be a chance finding or, alternatively, only part of the story, the disease only being manifest when the abnormal haemoglobin is accompanied by some unidentified interacting factor. A detailed study of other red cell components is clearly indicated in all cases. The difficulty of detecting some of the haemoglobin abnormalities suggests that other cases of unexplained haemolytic anaemia may also be due to the presence of an abnormal haemoglobin and that this may be detected only by the most careful studies. The properties of the various unstable haemoglobins described suggest that, in screening patients for this type of haemoglobin abnormality, electrophoresis of both the oxy- and the methaemoglobin derivatives in starch gel, using a number of different buffer systems at several $p H$ values, should be carried out. The finding of $\mathrm{Hb}-\alpha^{\mathrm{A}}$ in the haemolysate or the presence of a heat-unstable fraction may be the first indication that one is dealing with a haemoglobin abnormality.

The reasons why these haemoglobins are less stable than $\mathrm{Hb}-\mathrm{A}$ are not clear. It can be postulated that the presence of a different amino acid in the critical region near the haem group causes a strain in the molecule leading to some conformational changes, thus producing a less stable molecule.

(iv) Haemoglobinopathies Associated with the Homozygous State. These have been well described and comprise $\mathrm{Hb}-\mathrm{C}$ disease (Spaet, Alway, and Ward, I953), Hb-E disease (Lehmann, Story, and Thein, 1956; Na-Nakorn and Minnich, 1957), and Hb-D disease (Bird and Lehmann, 1956).

There is mild haemolysis which is not fully compensated, leading to haemoglobin levels of IO-12 $\mathrm{g}$. per $100 \mathrm{ml}$. The stained blood film shows some hypochromia and target cells. These diseases are found in subjects who are homozygous for any one of the above abnormal haemoglobins, the heterozygous condition being benign. The cause of the haemolysis in these syndromes is not clear but may arise because these haemoglobins show a slight instability which is not enough to cause disease when present together with $\mathrm{Hb}-\mathrm{A}$. It is also puzzling that in these cases the mild haemolysis is not fully compensated by increased red cell production, though more severe haemolysis, as, for example, in Hb-St. Mary's disease, shows so much better compensation.

\section{The Thalassaemias}

The characteristic abnormality in thalassaemia is the reduction in the amount of haemoglobin in the red cells due to diminished haemoglobin synthesis. As haemoglobin consists of the prosthetic haem group joined to the protein moiety, globin, impairment of haemoglobin synthesis could be due either to diminished synthesis of haem or globin.

The finding of Bannerman, Grinstein, and Moore (1959) of impaired incorporation of ${ }^{14} \mathrm{C}$-glycine into haem and some haem precursors in in vitro bone marrow cultures prepared from patients with thalassaemia appeared to support the idea that the prime abnormality of this disease was an abnormality of haem synthesis. On the other hand, the well-documented clinical observation that infants with thalassaemia major are normal at birth, developing the disease at about 3-6 months of age, is opposed to the idea that the primary abnormality is a defect in haem synthesis. This is because the haem groups of foetal haemoglobin and adult haemoglobin are identical, namely, ferrous protoporphyrin IX, and hence impairment of its synthesis should lead to anaemia during foetal as well as adult life. On the other hand, the protein part of these molecules differs, containing 
$\gamma$-chains in foetal haemoglobin $\left(\alpha_{2} \gamma_{2}\right)$ and $\beta$-chains in adult haemoglobin $\left(\alpha_{2} \beta_{2}\right)$. Recent work has shown that haem exerts a negative feedback on the synthesis of $\delta$-amino-laevulinic acid (ALA) in red cell precursors (Lascelles, 1960; Burnham and Lascelles, 1963; London, 1964; Steiner, Baldini, and Dameshek, 1964). The reduced rate of haem synthesis in thalassaemia can thus be explained by 'feedback' inhibition of the synthesis of $\delta$-ALA by the un-utilized haem formed in the thalassaemic red cell. Finally, Marks and Burka (1964) have shown that the synthesis of $\beta$-chains is impaired in the 'cell-free system' prepared with ribosomes from $\beta$-thalassaemic red cell precursors. From these considerations it appears that thalassaemia is an abnormality of globin synthesis.

It has already been noted that the $\alpha$-and $\beta$-chains of haemoglobin are synthesized independently and are under separate genetic control. This implies that, just as there are two main groups of abnormal haemoglobins, $\alpha$-chain variants and $\beta$-chain variants, there would also be two groups of thalassaemias, one affecting the synthesis of $\alpha$-chains and one affecting the synthesis of $\beta$-chains, and these have been called $\alpha$-thalassaemia and $\beta$-thalassaemia respectively (Ingram and Stretton, 1959). As there are also $\delta$ - and $\gamma$-chain haemoglobin variants, it might be expected that $\delta$ - and $\gamma$-thalassaemia also occur. One person without any $\mathrm{Hb}-\mathrm{A}_{2}$ has been reported, and he may be an example of $\delta$-thalassaemia (Fessas and Stamatoyannopoulos, 1962). The existence of $\gamma$-thalassaemia has also been claimed (Hamilton, Sheets, and Brosseau, 1962). However, the only two established groups are $\alpha$ - and $\beta$-thalassaemia.

The genes causing thalassaemia can, of course, occur in the heterozygous or homozygous state. Furthermore, it might be envisaged that there are a number of different mutations leading to varying degrees of impairment of polypeptide chain synthesis. Some mutations would completely, or almost completely, inhibit the synthesis of a particular polypeptide chain, while others would only partially inhibit it. This hypothesis implies that there is a whole range of mutations causing varying degrees of inhibition in the synthesis of either the $\alpha$ - or $\beta$-chains. In the simple heterozygote it is difficult to measure the degree of inhibition of any particular thalassaemia gene. However, an approximate measure of the degree of inhibition caused by a given thalassaemia gene is shown by the proportion of $\mathrm{Hb}-\mathrm{A}$ found in subjects who carry an abnormal haemoglobin. This is illustrated in mixed heterozygotes for ${ }^{\circ}$ $\beta$-thalassaemia and $\mathrm{Hb}-\mathrm{S}$ or $\mathrm{Hb}-\mathrm{C}$. If no $\mathrm{Hb}-\mathrm{A}$ is found, it may be inferred that complete sup- $\frac{\mathbb{D}}{D}$ pression of $\beta^{\mathrm{A}}$-chains has been caused by the $\stackrel{\mathbb{P}}{+}$ thalassaemia gene. In others, various amounts of $\overrightarrow{\vec{F}}$ $\mathrm{Hb}-\mathrm{A}$ are found, due to different degrees of $\stackrel{\vec{\rho}}{+}$ inhibition of $\beta^{A}$-chain synthesis. The same argu- $\frac{\text { C }}{2}$ ment applies to $\alpha$-thalassaemia interacting with 흠 haemoglobins with abnormal $\alpha$-chains. A full $\frac{\infty}{\widetilde{\Phi}}$ review of the thalassaemias has recently been $\AA$ published by Motulsky (1964b).

Classification. On the basis of the above hypothesis, the various thalassaemic syndromes $\vec{\omega}$ that have been described can be classified as shown ? below. It should be pointed out that though this classification does not embrace every described variant of thalassaemia, it does provide a useful way of categorizing these syndromes.

\section{(i) $\beta$-THALASSAEMI A}

(a) $\beta$-thalassaemia Trait. This is a mild anaemia $\vec{z}$ with the morphological changes in the blood smear typical of thalassaemia as well as a raised $\stackrel{\rho}{\supset}$ $\mathrm{Hb}-\mathrm{A}_{2}$ (Gerald and Diamond, 1958a). The increase $\vec{\bullet}$ in the proportion of $\mathrm{Hb}-\mathrm{A}_{2}$ is thought to be due $\mathrm{O}$ to the continued synthesis of $\mathrm{Hb}-\mathrm{A}_{2}$ at a normal rate while that of $\mathrm{Hb}-\mathrm{A}$ is impaired. In a proportion of these subjects, the foetal haemoglobin is also raised $2-5 \%$ above the normal maximum levelo of $0.4 \%$. In those who carry a $\beta$-thalassaemia $\frac{0}{D}$ gene, which only partially inhibits the synthesis of $\mathrm{Hb}-\mathrm{A}$, the proportion of $\mathrm{Hb}-\mathrm{A}_{2}$ might be only $\overrightarrow{\vec{O}}$ slightly increased. Several authors (Zuelzer, 3 Robinson, and Booker, 1961; Malamos, Fessas, and Stamatoyannopoulos, I962; Fessas, 1964) have? described a form of thalassaemia trait affecting the synthesis of $\beta$-chains in which $\mathrm{Hb}-\mathrm{A}_{2}$ is presento in normal concentration but $\mathrm{Hb}-\mathrm{F}$ is increased, 욱 and it is possible that this is due to a mutation. suppressing both $\beta$ - and $\delta$-chain synthesis $(\beta-\delta$-O응 thalassaemia) (Motulsky, 1964b).

(b) $\beta$-thalassaemia Major. This is the classicalo thalassaemia major. Family studies have shown $>$ that these persons have inherited two $\beta$-thalassaemia genes (Gerald and Diamond, 1958b). Becausen $\beta$-chain synthesis is almost completely inhibited, $a$ severe disease results which begins at the time $\mathcal{N}$ in development when $\gamma$-chain synthesis normally ceases and $\beta$-chain synthesis commences. The severe anaemia produces a stress situation in theo erythroid marrow, which, by a mechanism not yet understood, leads to the continuation of Hb-F $\stackrel{\oplus}{\oplus}$ synthesis but at a rate far below that necessary 0 for complete compensation. It appears that the $\mathrm{Hb}-\mathrm{F}$ produced by such a situation is unevenly@ distributed among the red cells (cf., sickle cell $\stackrel{\mathbb{Q}}{\varrho}$ 
disease-Singer and Fisher, 1952). This results in the production of red cells containing varying amounts of haemoglobin. Those cells that contain very little haemoglobin are destroyed in the marrow, the so-called 'ineffective erythropoiesis' which is a prominent feature of the disease. The remaining (smaller) proportion reaches the circulation.

One of the puzzling features of $\beta$-thalassaemia is that though the proportion of $\mathrm{Hb}-\mathrm{A}_{2}$ is raised in $\beta$-thalassaemia trait, it is normal or low in the homozygous state. If $\delta$-chain synthesis were proceeding at a normal rate, it might be expected that $\mathrm{Hb}-\mathrm{A}_{2}$ would be much higher in the homozygous condition than in the trait form. A possible explanation is that the continued synthesis of $\gamma$-chains suppresses that of the $\delta$-chains by some kind of 'feedback' mechanism.

(c) $\beta$-thalassaemia Intermedia. As the name implies, this disease is of intermediate severity to $\beta$-thalassaemia major and minor. It is characterized by a haemoglobin of 6-10 g. per $100 \mathrm{ml}$. with the typical blood picture of thalassaemia. Usually, there is gross splenic enlargement as well as the bone changes seen in thalassaemia major. $\mathrm{Hb}-\mathrm{F}$ is raised from $20-80 \%$ and the proportion of $\mathrm{Hb}-\mathrm{A}_{2}$ is often greater than normal. Family studies often do not show the $\beta$-thalassaemia trait in both parents, and it is presumed that genetically this condition is due to the interaction of two $\beta$ thalassaemia genes, one of which completely inhibits $\beta$-chain synthesis, while the other causes only partial inhibition. This clinical syndrome is also found in patients suffering from Hb-Leporethalassaemia disease (Gerald and Diamond, 1958b; Fessas et al., 1962; Neeb et al., I961; Pearson, Gerald, and Diamond, 1959; Beaven, Gratzer, Stevens, Shooter, Ellis, White, and Gillespie, 1964) or homozygous Lepore disease (Neeb et al., 1961; Fessas et al., 1962). In both these conditions, a large proportion of the haemoglobin formed in the red cells is Hb-F. Milder clinical syndromes of this type are the well-documented interactions of abnormal haemoglobins such as $\mathrm{Hb}-\mathrm{C}$, Hb-E, or Hb-D with $\beta$-thalassaemia described below.

(d) Interaction of $\beta$-thalassaemia with a $\beta$-chain Variant of $\mathrm{Hb}-\mathrm{A}$. Hb-S thalassaemia disease is a clinical variant of sickle cell disease (Singer, Singer, and Goldberg, 1955). Hb-C-thalassaemia disease (Singer, Kraus, Singer, Rubinstein, and Goldberg, 1954; Zuelzer and Kaplan, 1954), Hb-D-thalassaemia disease (Hynes and Lehmann, 1956), and Hb-E-thalassaemia disease (Na-Nakorn and Minnich, 1957; Kochhar and Kathpalia, 1963) are some interactions of this type. Clinically, these are variants of thalassaemia of intermediate to mild severity. The diagnosis is made from the clinical picture and the electrophoretic analysis of the haemolysates. Often the abnormal haemoglobin and $\mathrm{Hb}-\mathrm{A}$ will be found, but the proportion of $\mathrm{Hb}-\mathrm{A}$ is lower than $50 \%$, whereas in the simple abnormal haemoglobin trait $\mathrm{Hb}-\mathrm{A}$ usually exceeds the abnormal haemoglobins in amount. In some patients, no Hb-A is synthesized, and the differentiation from the homozygous haemoglobinopathies rests on family studies. Hb-Lepore-thalassaemia disease (Gerald and Diamond, 1958b) is a much more severe disease closely resembling thalassaemia major, with a haemoglobin level of approximately $8 \mathrm{~g}$. per $100 \mathrm{ml}$. The main pigment in the red cells is $\mathrm{Hb}-\mathrm{F}(65-70 \%)$ with $5-7 \% \mathrm{Hb}$-Lepore and a low level of $\mathrm{Hb}-\mathrm{A}_{2}$.

(ii) INTERACTION OF $\alpha$ - WITH $\beta$-THALASSAEMIA (Fessas, 1962). Clinically, this disease is a form of thalassaemia minor. The diagnosis can only be established by family studies.

(iii) $\alpha$-THALASSAEMIA. As the $\alpha$-chains of Hb-A, $\mathrm{Hb}-\mathrm{F}$, and $\mathrm{Hb}-\mathrm{A}_{2}$ are identical, $\alpha$-thalassaemia affects haemoglobin production both before birth as well as later in life, and it appears that the effect is clinically more severe during foetal life than later.

(a) $\alpha$-thalassaemia Trait. This trait is somewhat milder than the $\beta$-thalassaemia trait, presumably because there is good compensation by the remaining normal $\mathrm{Hb}_{\alpha}$ gene. The clinical features of the trait in persons in whom one $\mathrm{Hb}_{\alpha}$ gene is completely inhibited have been outlined by Malamos et al. (1962). At birth, these people carry 5-10\% $\mathrm{Hb}-\gamma_{4}$, and this disappears during the neonatal period together with $\mathrm{Hb}-\mathrm{F}$. Later in life, the patient has a slight anaemia, with a blood film suggesting thalassaemia. The $\mathrm{Hb}-\mathrm{A}_{2}$ level is normal. There are no clinical signs. The diagnosis can be confirmed by finding occasional cells with inclusion bodies after incubation with brilliant cresyl blue. In a few patients, a trace of $\mathrm{Hb}-\gamma_{4}$ is found in the haemolysate.

Subjects who inherit an $\alpha$-thalassaemia gene which only partially suppresses the synthesis of $\alpha$-chains have no detectable abnormality later in life but at birth have a slight increase of $\mathrm{Hb}-\gamma_{4}$ in the range of $1-2 \%$.

(b) $\alpha$-thalassaemia Major. This is due to the inheritance of two $\alpha$-thalassaemia genes causing severe $\alpha$-chain suppression (see above). In these subjects, no $\alpha$-chains are synthesized, and death in utero apparently occurs at approximately 32 
weeks' gestation and the foetus shows severe hydrops foetalis, anaemia, and erythroblastosis. (Lie-Injo Luan Eng and Jo Biwan Hie, I960; Lie-Injo Luan Eng and Lie Hong Gie, r96I; Lie-Injo Luan Eng, 1962).

(c) $\alpha$-thalassaemia Intermedia or Haemoglobin $H$ Disease. Recent work on $\mathrm{Hb}-\mathrm{H}$ disease leaves little doubt that it is caused solely by a deficiency of $\alpha$-chain synthesis. Since the $\alpha$-chains for the three normal haemoglobins, $\mathrm{Hb}-\mathrm{A}, \mathrm{Hb}-\mathrm{A}_{2}$, and $\mathrm{Hb}-\mathrm{F}$, are derived from a common metabolic pool, $\alpha$-chain deficiency should lead not only to the formation of $\mathrm{Hb}-\beta_{4}$, but also in the same person to the formation of haemoglobins consisting solely of $\gamma$ - and $\delta$-chains, $\mathrm{Hb}-\gamma_{4}$ and $\mathrm{Hb}-\delta$, respectively. The fact that this occurs has recently been demonstrated in four patients with $\mathrm{Hb}-\mathrm{H}$ disease (Dance, Huehns, and Beaven, 1963). The finding that some of the $\delta$-chains synthesized are used in the formation of $\mathrm{Hb}-\delta$ accounts for the low levels of $\mathrm{Hb}-\mathrm{A}_{2}$ found consistently in the disease. Secondly, the occurrence of $\mathrm{Hb}-\gamma_{4}$ without $\mathrm{Hb}-\beta_{4}$ in some of the individuals who are synthesizing both $\beta$ - and $\gamma$-chains must be explained. It has previously been suggested that the available $\alpha$-chains are used preferentially for the formation of $\mathrm{Hb}-\mathrm{A}$ rather than Hb-F (Huehns, Flynn, Butler and Shooter, 1960), and this has been confirmed by in vitro recombination experiments using the isolated chain subunits (Huehns, Beaven, and Stevens, 1964e). When the published pedigrees of families with $\mathrm{Hb}-\mathrm{H}$ disease are studied, it appears likely that the disease is caused by the interaction of two abnormal genes. The occurrence of detectable $\alpha$-thalassaemia trait in some of the relatives is well documented. Huehns et al. (1960) have suggested that $\mathrm{Hb}-\mathrm{H}$ disease is due to two $\alpha$-thalassaemia genes. The work of Lie Injo Luan Eng already referred to indicates that the inheritance of two severe $\alpha$-thalassaemia genes leads to intrauterine death. It is therefore suggested that $\mathrm{Hb}-\mathrm{H}$ disease is caused by the interaction of a severe $\alpha$-thalassaemia gene (causing complete suppression of $\alpha$-chain synthesis) with a milder $\alpha$-thalassaemia gene (causing partial suppression of $\alpha$-chain synthesis) (Huehns, 1962). As the incidence of the severe type of $\alpha$-thalassaemia genes is known (Malamos et al., 1962), the occurrence of families in which $\mathrm{Hb}-\mathrm{H}$ appears in several generations (Gouttas et al., 1955; Bingle, Huehns, and Prankerd, 1958; Ramot, Sheba, Fisher, Ager, and Lehmann, 1959; Minnich, Na-Nakorn, Tuchinda, Pravit, and Moore, 1956) indicates that the mild $\alpha$-thalassaemia gene is relatively common, occurring in approximately $20 \%$ of the population.
The published family data of $\mathrm{Hb}-\mathrm{H}$ disease are consistent with this hypothesis (E. R. Huehns ? and A. G. Motulsky, unpublished; Wasi, NaNakorn, and Suingdamrong, 1964). Confirmation of this explanation for $\mathrm{Hb}-\mathrm{H}$ disease could be obtained if it is shown that all newborns from parents with the disease carry some $\mathrm{Hb}-\gamma_{4}$, and also if the incidence in the affected population of the mild type of $\alpha$-thalassaemia gene postulated क above could be shown to be approximately $20 \%$. $\overrightarrow{0}$ To date five newborns from patients with $\mathrm{Hb}-\mathrm{H}$ disease have been examined and four of these $\vec{\omega}$ carried increased amounts of $\mathrm{Hb}-\gamma_{4}$ (Fessas 1960 ; E. R. Huehns, unpublished). It is, however, not known whether the methods used would have if detected the small increases postulated to occur in some of these cases.

(d) The Interaction of $\alpha$-thalassaemia With an 윽 $\alpha$-chain Variant of Haemoglobin A. Hb-Q- $\alpha--$ thalassaemia disease clinically resembles $\mathrm{Hb}-\mathrm{H} \$ disease, except that instead of $\mathrm{Hb}-\mathrm{A}, \mathrm{Hb}-\mathrm{Q}$ is found (Vella, Wells, Ager, and Lehmann, I958; Dormandy et al., 196r; Lie-Injo Luan Eng and $\vec{\bullet}$ Hart, 1963). Because no $\mathrm{Hb}-\mathrm{A}$ is present in these of cases, the $\alpha$-thalassaemia would be of the severe 0 type. One patient with $\mathrm{Hb}$-I- $\alpha$-thalassaemia disease has been described (Atwater et al., 1960a). Clinically, the picture was that of thalassaemia. The patient's haemolysate showed approximately $80 \% \mathrm{Hb}-\mathrm{I}$ and $20 \% \mathrm{Hb}-\mathrm{A}$; $\mathrm{Hb}-\mathrm{A}_{2}$ and $\mathrm{Hb}-\mathrm{I}_{2} \mathrm{O}$ were also present (Atwater et al., 196I). In this case, the $\alpha$-thalassaemia allowed the formation of significant amounts of $\mathrm{Hb}-\mathrm{A}$ and was therefore of the mild type.

The Genetic Abnormality in Thalassaemia. During the past few years, consideration has been given to the type of mutation that gives rise to thalassaemia. Studies of offspring in families in which $\beta$-thalassaemia and abnormal haemoglobins occur indicate that the genetic loci controlling the synthesis of the $\beta$-chains and those causing $\frac{D}{O}$ $\beta$-thalassaemia are either allelic or closely linked (see above). Several hypotheses have been ad- N vanced.

(a) The rate of haemoglobin synthesis is diminished because the ' $\mathrm{Hb}-\mathrm{A}$ ' synthesized in these $\mathrm{C}$ persons is not normal Hb-A but contains a 'silent' amino acid substitution (Itano, 1957; Ingram 0 and Stretton, 1959). The finding (Guidotti, G., quoted by Baglioni, I963a) that the amino acid? composition of isolated peptides from two such samples of ' $\mathrm{Hb}-\mathrm{A}$ ' was identical to normal $\mathrm{Hb}-\mathrm{A}$ argues against this idea but does not altogether exclude it. 
(b) The alternative view that the reduced rate of synthesis is due to a mutation of a closelylinked rate-controlling locus, such as the operator locus postulated in the control of bacterial protein synthesis by Jacob and Monod (1961), has been discussed by a number of workers (Neel, I96I; Motulsky, 1962; Sturgeon et al., 1963; Zuckerkandl, 1964). However, these hypotheses do not explain all the findings in thalassaemia.

(c) Recently, Itano (1964) has advanced a third hypothesis. This depends on the idea that the genetic code is degenerate, that is, that two different triplet code words (see above) can code for the same amino acid. In normal persons, the normal triplet code word is present, but in thalassaemic persons, the normal code triplet is replaced by a different one which codes for the same amino acid. One of the factors that limits the rate of addition of any particular amino acid to the growing end of a polypeptide chain during synthesis is the availability of amino acid transfer-RNA fitting any particular coding triplet, and it is argued that there is plenty of transfer-RNA to fit the normal coding triplet but a deficiency of transfer-RNA for the abnormal triplet. This deficiency of availability of a particular amino acid leads to a block in the synthesis of the affected polypeptide chain and the decreased normal globin production seen in thalassaemia.

(d) Ingram (1964) has put forward still another hypothesis. This proposes that in thalassaemia the messenger RNA for the affected chain is abnormal and blocks some of the ribosomal sites of protein synthesis so that they are not available for haemoglobin synthesis.

(e) Another possibility is that the messenger RNA formed, if abnormal, would be less stable than normal in mRNA. Each mRNA would then only be available for the synthesis of a smaller number of polypeptide chains than its normal counterpart.

The multiplicity of hypotheses put forward to explain the findings in thalassaemia indicates that at the present time the data on which a sound theory can be based are not yet available, and it is possible that there is more than one cause of thalassaemia.

\section{The Hereditary Persistence of Foetal Haemoglobin}

A number of investigators have described a benign condition in Negroes in which the production of $\mathrm{Hb}-\mathrm{F}$ continues into adult life, $20-30 \%$ of total haemoglobin being foetal in type, the re- mainder being $\mathrm{Hb}-\mathrm{A}$ and $\mathrm{Hb}-\mathrm{A}_{2}$ (Edington and Lehmann, I955a, b; Jacob and Raper, 1958; Went and MacIver, 1958; Herman and Conley, 1960; Bradley et al., I96I; Kraus, Koch, and Burkett, 196I; Thompson, Mitchener, and Huisman, 196I ; Conley et al., 1963). It occurs in about $1 \%$ of American Negroes. The distribution in Africa is not known in detail, but about $1 \%$ of the population is affected in West Africa (Conley et al., I963). Several studies have indicated that the foetal haemoglobin in these persons is the same as that found in normal cord blood (Thompson et al., 196r; Schroeder, Sturgeon, and Bergren, 1962; Baglioni, 1963b). The foetal haemoglobin is uniformly distributed in the red cells (Thompson et al., I96I; Bradley et al., 196I). This contrasts with the finding of uneven $\mathrm{Hb}-\mathrm{F}$ distribution in the red cells in other conditions, such as sickle cell anaemia (Singer and Fisher, 1952) or thalassaemia major (Shepard, Weatherall, and Conley, 1962), where the persistence of $\mathrm{Hb}-\mathrm{F}$ is not the direct result of the genetic abnormality but secondary to a stress situation in the bone marrow.

When a person inherits this condition as well as a gene causing the production of a haemoglobin variant with abnormal $\beta$-chains, no $\mathrm{Hb}-\mathrm{A}$ is produced*. When such persons are mated to normal persons, their children carry either the 'high $\mathrm{F}$ gene' or the abnormal haemoglobin (Thompson and Lehmann, 1962; Conley et al., 1963; see also Rucknagel and Neel, 196I), indicating that the 'high $\mathrm{F}$ gene' is closely linked or allelic to the $\mathrm{Hb}_{\beta}$ locus. Whether the $\gamma$-chain structural locus is linked to that at which the 'high F gene' is situated is not known. Data on this point will come from the study of families in which both the "high $F$ gene' and a $\gamma$-chain variant of $\mathrm{Hb}-\mathrm{F}$ are found.

Besides the interaction with abnormal haemoglobins, interaction with $\beta$-thalassaemia has been reported. These patients have approximately 65$70 \% \mathrm{Hb}-\mathrm{F}$ and the clinical picture of thalassaemia intermedia (Kraus et al., I96I; Wheeler and Krevans, I96r ; Barkham and Adinolfi, 1962).

One person probably homozygous for the 'high F gene' has been reported (Wheeler and Krevans, 1961). He had only slight haematological abnormality; he carried only $\mathrm{Hb}-\mathrm{F}$, and no $\mathrm{Hb}-\mathrm{A}$ or $\mathrm{Hb}-\mathrm{A}_{\mathbf{2}}$ could be detected.

\footnotetext{
* These people carry these traits in repulsion. If the 'high $\mathrm{F}$ gene' occurred in coupling to an abnormal $\mathrm{Hb}_{\beta}$ gene, the production of the corresponding abnormal haemoglobin would be suppressed and the phenotype could not be distinguished from the simple trait. The same applies to the progeny of the matings mentioned, and the only cross-over that could be distinguished would be one that leads to a normal person.
} 
Several hypotheses to explain these findings have been advanced. Wheeler and Krevans (196I) suggest that it might be due to a deletion of the $\mathrm{Hb}_{\beta}$ and $\mathrm{Hb}_{\delta}$ loci. The deletion must also lead to the continued production of $\mathrm{Hb}-\mathrm{F}$ in sufficient amounts to compensate for the lack of $\mathrm{Hb}-\mathrm{A}$ production. Other workers (Neel, I96I; Motulsky, I962; Sturgeon et al., 1963; Zuckerkandl, 1964) have postulated that it is due to a mutation affecting the regulatory mechanism controlling the $\mathrm{Hb}_{\beta}$ and $\mathrm{Hb}_{\delta}$ loci, leading to failure to turn on the synthesis of these chains and at the same time failure to turn off $\gamma$-chain production.

Two further types of inherited persistence of foetal haemoglobin have been described, which differ from the 'high $F$ gene' described above in that the amount of $\mathrm{Hb}-\mathrm{F}$ found in the heterozygotes is significantly lower. The first occurs in $0.25 \%$ of Greeks (Fessas and Stamatoyannopoulos, 1964). In these individuals, $\mathrm{Hb}-\mathrm{F}$ levels vary from II$18 \%$, and $\mathrm{Hb}-\mathrm{A}_{2}$ is within the lower range of normal. There are no haematological abnormalities, and $\mathrm{Hb}-\mathrm{F}$ is evenly distributed in all red cells. This trait has also been described in association with $\beta$-thalassaemia; clinically, this is a form of $\beta$ thalassaemia intermedia, with $20-40 \% \mathrm{Hb}-\mathrm{F}$ and a raised $\mathrm{Hb}-\mathrm{A}_{2}$. The other type occurs in about $\mathrm{I} \%$ of the population of Southern Switzerland. It is not associated with any clinical or haematological abnormality (Marti and Bütler, 196I; Marti, 1963).

\section{The Occurrence of Haemoglobin Abnormalities in Other Diseases}

Haemoglobin $\mathbf{A}_{2}$. Variation between normal people in the level of $\mathrm{Hb}-\mathrm{A}_{2}$ is small, and there is also little variation in disease besides that occurring in thalassaemia. There is one report that $\mathrm{Hb}-\mathrm{A}_{2}$ is raised in pernicious anaemia and low in irondeficiency anaemia (Josephson, Masri, Singer, Dworkin, and Singer, 1958). Another report suggests that $\mathrm{Hb}-\mathrm{A}_{2}$ is raised after bone marrow transplantation (Bridges, Neill, and Lehmann, I96I). From the small amount of data available, it is not possible to determine whether the above changes are present in all patients.

Haemoglobin F (for review, see Beaven et al., 1960b). Delayed disappearance of $\mathrm{Hb}-\mathrm{F}$ after birth is associated with a number of conditions such as prematurity (Jonxis, I95I), congenital spherocytosis, and other congenital haemolytic anaemias. The foetal haemoglobin levels in these infants eventually reach normal levels. There is also a delay in the disappearance of $\mathrm{Hb}-\mathrm{F}$ in trisomy $13-15$ and in a proportion of Negroes with: Down's syndrome (trisomy 21-22) already referred to.

In acute leukaemia in young children, high $\mathrm{Hb}-\mathrm{F}$ levels are often found. In adult patients with leukaemia, small increases in $\mathrm{Hb}-\mathrm{F}$ are occasionally found, particularly in patients with erythroleukaemia. A raised $\mathrm{Hb}-\mathrm{F}$ has also been reported in ${ }^{\infty}$ aplastic anaemia (Jones, 196r; Jonxis, 196I). In $\vec{\circ}$ pernicious anaemia, $\mathrm{Hb}-\mathrm{F}$ is present in smallamounts $(\mathrm{I}-2 \%)$ in approximately half the patients $\mathrm{\sigma}^{\omega}$ examined. It is of interest that the proportion of this pigment often rises shortly after the com-6 mencement of treatment with vitamin $B_{12}$ before? the maximum reticulocyte response has been reached $d_{\vec{D}}$ (Beaven et al., 1960b).

Small amounts of foetal haemoglobin have also을 been found in approximately $10 \%$ of women during $\overrightarrow{-}$ the second trimester of pregnancy by a sensitive immunological technique. These slightly raised levels fall to normal adult levels in the last trimester (Rucknagel and Chernoff, 1955). The occasionalo finding of high $\mathrm{Hb}-\mathrm{F}$ levels in late pregnancy may. indicate transplacental foetal haemorrhage. Bromberg, Salzberger, and Abrahamov (1957) report a乏 significantly raised $\mathrm{Hb}-\mathrm{F}$ in four patients with $\mathrm{a} \frac{\mathrm{O}}{\mathrm{O}}$ molar pregnancy.

Iron deficiency, acquired haemolytic anaemias, and congenital cyanotic heart disease are not associated with a raised $\mathrm{Hb}-\mathrm{F}$.

Haemoglobin H. A number of patients with $\mathrm{Hb}-\mathrm{H}$ in association with erythroleukaemia have been described (Bergren and Sturgeon, 1960: White, Ellis, Coleman, Beaven, Gratzer, Shooter, and Skinner, 1960; Beaven, Stevens, Dance, and 3 . White, 1963; C. A. Finch, A. G. Motulsky, un-o̊ published). The red cells in these patients show hypochromia and some target cells and resembleo those seen in the congenital form of $\mathrm{Hb}-\mathrm{H}$ disease. As these patients come from populations in which $\mathrm{Hb}-\mathrm{H}$ disease has not been reported, it appears that the appearance of this abnormalos haemoglobin is due to the leukaemia. In two off them, small amounts of $\mathrm{Hb}-\gamma_{4}$ were also presentus (E. R. Huehns, unpublished). Another report of an unstable haemoglobin associated with leukaemia comes from India (Mathur and Misra, 1962).

Sickle Cell Trait. There is one report of avariation in the proportion of $\mathrm{Hb}-\mathrm{A}$ to $\mathrm{Hb}-\mathrm{S}$ in megaloblastic anaemia (Heller, Yakulis, Epstein, $\overrightarrow{\mathbb{D}}$ and Friedland, 1963). It was found that the pro- $\frac{\mathrm{O}}{\mathrm{O}}$ portion of $\mathrm{Hb}-\mathrm{S}$ present was unusually low when the 
patient was first seen. After recovery from the anaemia, the proportion of $\mathrm{Hb}-\mathrm{S}$ increased significantly.

Animal Haemoglobins. Van Vliet and Huisman (1964) have studied experimental anaemia in sheep and shown definitive changes in the relative proportion of types of haemoglobin present in the red cells. If the experimental animals were allowed to recover, the haemoglobin pattern returned to that at the beginning of the study.

\section{Distribution of Abnormalities of Haemoglobin Synthesis}

Since the discovery of the abnormal haemoglobin, it has been shown that some, such as $\mathrm{Hb}-\mathrm{S}, \mathrm{Hb}-\mathrm{C}$, $\mathrm{Hb}-\mathrm{D}$, and $\mathrm{Hb}-\mathrm{E}$, occur quite frequently in some parts of the world, while in others they are only found occasionally. It has also been found that the thalassaemias only have a high incidence in certain areas. The harmful, and often lethal, effects of these inherited abnormalities in the homozygous state raise the problem of why these deleterious genes are not rapidly eliminated from the population. Theoretically, this can be prevented if the heterozygous state confers some compensating advantage (heterosis) and is fitter in the Darwinian sense than either the normal or abnormal homozygote. At certain frequencies the harmful effects of the abnormal gene in a given population will be exactly balanced by the conferred advantage. Such an equilibrium is stable and is known as a balanced polymorphism (Stern, 1960). In other words, if homozygotes die prematurely or are so infertile that they seldom reproduce (and hence do not transmit the abnormal gene), their Darwinian fitness is said to be near zero. The gene can, nevertheless, be maintained in the population if the heterozygotes are fitter than the normal homozygotes in this sense. This increased fitness may be due to a relative immunity to some disease which can cause premature mortality or impairs fertility. Clearly, such a disease must be prevalent in the areas in which the relevant red cell traits are found and much effort has been directed towards identifying such factors. Haldane (1949) suggested that thalassaemia protected against malaria. Allison (1954) drew attention to the possible role of sickle cell trait in protecting against malignant tertian malaria and provided the first data in support of this hypothesis. He also pointed out that in a hyperendemic region the effect should be most marked during the first years of life, before immunity to malaria is acquired. There is now a great deal of support for the hypothesis that the sickling trait protects against malaria, and in particular against plasmodium falciparum, and this hypothesis is now widely accepted. The importance of malaria in maintaining the frequency of thalassaemia is not yet fully documented. In relation to the other common haemoglobin traits, only scanty data are available. This interesting aspect of the haemoglobin story is discussed in more detail by a number of authors (Allison, 196I; Motulsky, I964a; Rucknagel and Neel, 196I; Livingstone, 1958; Allison, 1964).

The Distribution of Sickle Cell Trait. The distribution of the sickle cell gene is shown in Fig. 22. It can be seen that sickling occurs in tropical Africa and also in the Mediterranean region, southern Arabia, and India. Besides occurring in these areas, it is, of course, also found in emigré populations, such as the American and West Indian Negroes. The incidence of the gene varies enormously from place to place; the highest frequencies are found in certain peoples of East Africa, reaching $40 \%$ in Amba on the slopes of Mount Ruwenzori.

The distribution of the sickling gene, in general, corresponds well to that of falciparum malaria (Fig. 23). There are, however, areas where falciparum malaria is common and the sickling trait is not found, such as South-east Asia. The reasons for this are not entirely clear. It may be that the trait has never been introduced into these areas either by mutation or immigration. Alternatively, protection against malaria may be afforded by one of the other red cell traits. For example, in Southeast Asia Hb-E, thalassaemia, and glucose 6phosphate dehydrogenase (G6PD) deficiency all occur, and all are thought to give protection against malaria, the relatively more lethal sickle gene being excluded. This problem has been studied in Greece, where the sickle cell trait and thalassaemia are found. It was found that in regions where the sickle gene frequency is high, the frequency of thalassaemia is low and vice versa (Barnicot, Allison, Blumberg, Deliyannis, Krimbas, and Ballas, 1963). The theoretical aspects of this situation have been discussed by Penrose, Smith, and Sprott (1956).

It would be expected that considerable protection against death from malaria would be needed to balance the loss of sickle cell genes in regions where its frequency is high. The demonstration of this is one of the most vital links in the malaria hypothesis. In general, death rates from malaria are difficult to obtain, because it is often difficult to be sure that malaria, if present, is not just an incidental finding 


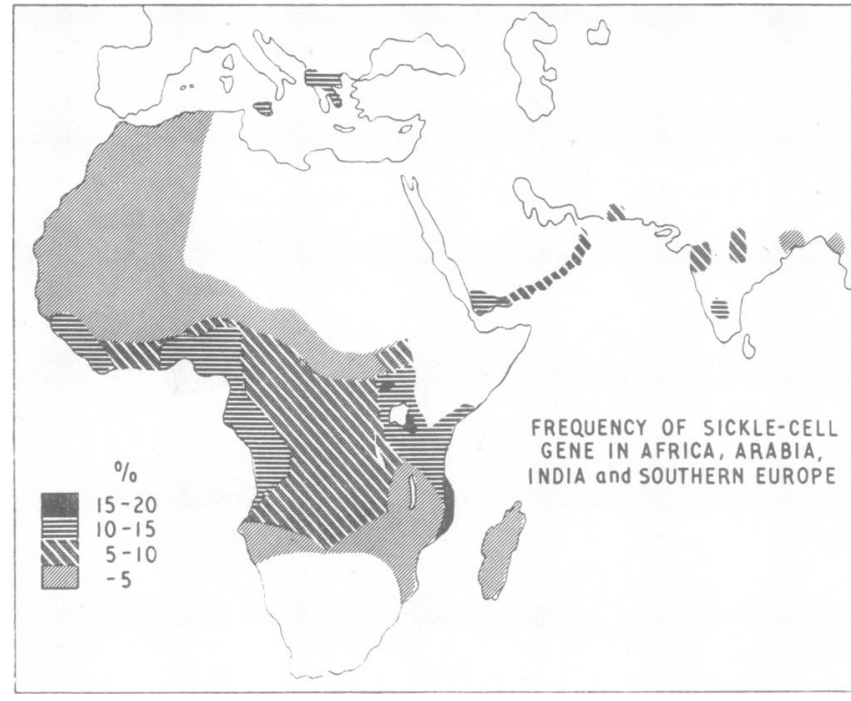

Frg. 22. Frequency of the sickle cell gene $\mathrm{Hb}_{\beta}^{\mathrm{S}}$ in various parts of the Old World (after Allison, 196r).

rather than the primary cause of death. Hence cerebral malaria provides the most favourable material for this kind of study. Several groups of workers have determined the incidence of sickling in infants dying from cerebral malaria and compared this with that found in the general population.
The results of these studies have been summarized by Motulsky (1964a) and $\Phi$ are given in Table IV. This shows that whereas 23 out of the I00 patients dying from cerebral malaria would have beeno expected to carry the sickling trait, only흐 one such patient was found, and this gives strong support to the hypothesis $\mathbb{\Omega}$ that the high incidence of sickling traito is due to its protection against death' from falciparum malaria.

The Distribution of Haemoglobin ${ }^{\omega}$ C. High frequencies of $\mathrm{Hb}-\mathrm{C}$ are only found in certain regions of West Africa, the trait reaching a frequency of almost ${ }_{-}^{N}$ $30 \%$. Besides this, sporadic cases are found elsewhere in the African continent. $\infty$ There is some evidence that in those areas where both $\mathrm{Hb}-\mathrm{S}$ and $\mathrm{Hb}-\mathrm{C}$ are $\overrightarrow{-}$ found in the population, their frequencies are inversely related (Rucknagel andō Neel, 196I). As might be expected, $\mathrm{Hb}-\mathrm{C}$ is also found in the Negro popu- $\mathscr{C}$ lations of America and the West Indies. The high frequency of $\mathrm{Hb}-\mathrm{C}$ is also thought to be due to its protective effect against malaria, and this is supported, but by no means proved, by the few studies that have been carried out (Motulsky, ֶ, 1964a). Hb-C disease is much milder than sickle $\stackrel{\mathbb{\perp}}{\circ}$ cell disease and an equilibrium frequency of $\mathrm{Hb}-\mathrm{C} \underset{\overrightarrow{\mathrm{O}}}{\Rightarrow}$

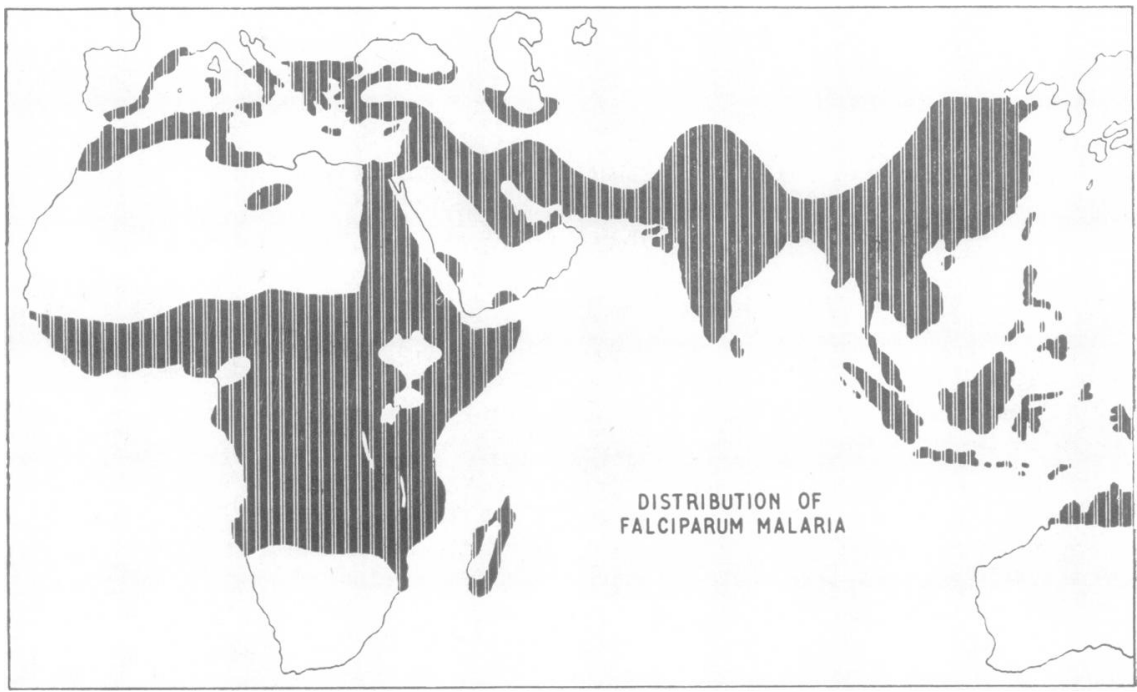

FIG. 23. Distribution of falciparum malaria before 1930 (from M. F. Boyd's Malariology). 
TABLE IV

MALARIAL MORTALITY IN Hb-S TRAIT (AS) (From Motulsky, 1964a)

\begin{tabular}{|c|c|c|c|c|}
\hline & $\underset{\text { Population }}{\stackrel{\%}{\text { AS in }}}$ & $\begin{array}{c}\text { No. Dead } \\
\text { From } \\
\text { Malaria }\end{array}$ & $\begin{array}{l}\text { Observed } \\
\text { No. AS } \\
\text { Dead From } \\
\text { Malaria }\end{array}$ & $\begin{array}{l}\text { Expected } \\
\text { No. AS } \\
\text { Dead From } \\
\text { Malaria }\end{array}$ \\
\hline $\begin{array}{l}\text { Leopoldville, Congo (Lambotte-Legrande and Lambotte-Legrande, 1958) } \\
\text { Luluaburg, Congo (Vandepitte and Delaisse, 1957) } \\
\text { Ibadan, Nigeria (Edington and Watson-Williams, 1964) } \\
\text { Accra, Ghana (Edington and Watson-Williams, I964) } \\
\text { Kampala, Uganda (Raper, I956) }\end{array}$ & $\begin{array}{r}26 \\
29 \\
24 \\
8 \\
19\end{array}$ & $\begin{array}{l}23 \\
21 \\
27 \\
13 \\
16\end{array}$ & $\begin{array}{l}0 \\
\mathbf{I} \\
0 \\
0 \\
0\end{array}$ & $\begin{array}{l}6 \\
6 \cdot 1 \\
6 \cdot 5 \\
1 \\
3\end{array}$ \\
\hline Total & & 100 & $I^{*}$ & $22 \cdot 6$ \\
\hline
\end{tabular}

$\chi^{2}=20.5 ; p<0.001$.

could be maintained by a much smaller selective advantage of the heterozygote than that conferred by the sickle cell trait, making it correspondingly more difficult to demonstrate.

The Distribution of Haemoglobin D. Hb-D is found sporadically in many parts of the world. It occurs somewhat more commonly in certain regions of India but even there the maximum incidence of the trait is $2 \%$ in Sikhs of the Punjab (Bird and Lehmann, 1956). As has already been mentioned, detailed studies of samples of $\mathrm{Hb}-\mathrm{D}$ have shown that there are several chemically distinct forms.

The Distribution of Haemoglobin E. This is shown in Fig. 24. It can be seen that $\mathrm{Hb}-\mathrm{E}$ is found almost exclusively in South-east Asia, although cases have been reported to occur as far away as Turkey (Aksoy and Lehmann, 1957). The distribution of the abnormal haemoglobins in Southeast Asia has recently been reviewed by Lie Injo Luan Eng (1964). The reasons for the frequency of $\mathrm{Hb}-\mathrm{E}$ in this region are not clear, but again protection against malaria has been suggested (Kruatrachue, Na-Nakorn, Charoenlarp, and Suwanakul, I96I; see Allison, I96I ; Motulsky, I964a).

The Distribution of Thalassaemia. The map shown in Fig. 25 does not differentiate between the distribution of $\alpha$ - and $\beta$-thalassaemia, but mainly represents that of the latter. $\alpha$-thalassaemia is, however, known to occur in at least some of the areas in which $\beta$-thalassaemia is present and has been reported from Italy, Greece, Israel, and other Eastern Mediterranean countries, South-east Asia, and West Africa (see Motulsky, 1964b). Again, it has been suggested that protection against falci-

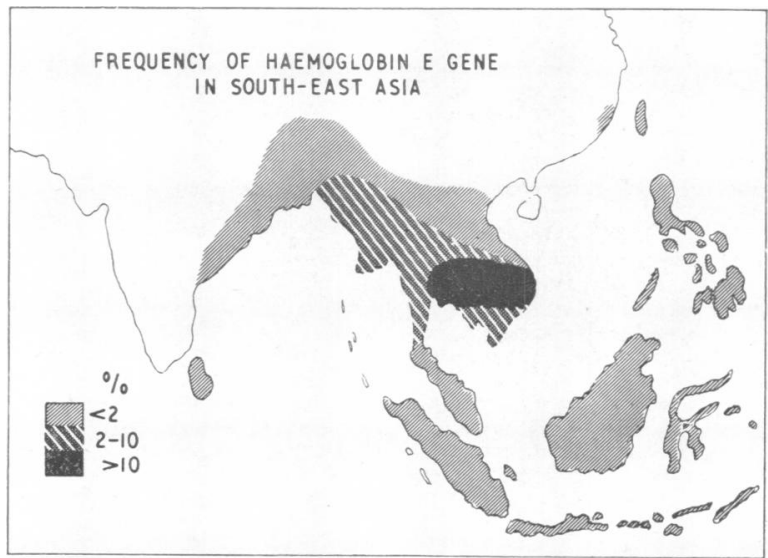

FIG. 24. Distribution of haemoglobin E (from Allison, 1961). 


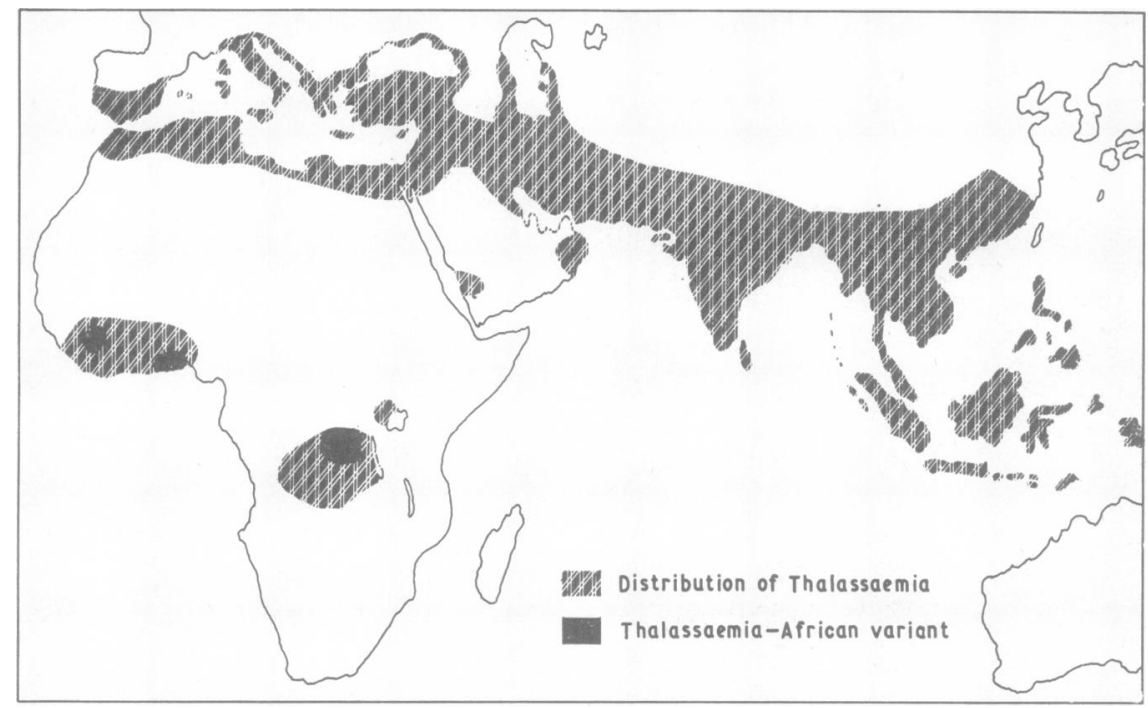

FIG. 25. Distribution of thalassaemia (from Allison, 196I).

parum malaria maintains the frequency of the thalassaemia traits, but the evidence for this is not nearly so convincing as in the case of the sickle cell trait.

We wish to thank Professor N. A. Barnicot for helpful discussion during the preparation of this review. The work was supported by grant $\mathrm{NB}-04270$ from the National Institute of Health.

\section{REFERENCES}

Ager, J. A. M., and Lehmann, H. (1958). Observations on some 'fast' haemoglobins: K, J, N, and 'Bart's'. Brit. med. F., I, 929.

Aksoy, M., and Lehmann, H. (1957). The first observation of sickle-cell haemoglobin E disease. Nature (Lond.), 179, 1248.

Allen, D. W., Schroeder, W. A., and Balog, J. (1958). Observations on the chromatographic heterogeneity of normal adult and fetal human haemoglobin: a study of the effects of crystallization and chromatography on the heterogeneity and isoleucine content. F. Amer. chem. Soc., 80, 1628.

Allison, A. C. (1954). The distribution of the sickle-cell trait in East Africa and elsewhere and its apparent relationship to the incidence of subtertian malaria. Trans. roy. Soc. trop. Med. Hyg., 48, 312.

(1961). Abnormal haemoglobin and erythrocyte enzymedeficiency traits. In Genetical Variation in Human Populations, ed. G. A. Harrison, p. 16, Pergamon Press, Oxford.

(1964). Polymorphism and natural selection in human populations. Cold Spr. Harb. Symp. quant. Biol., 29. In the press.

Anson, M. L., and Mirsky, A. E. (1930). Protein coagulation and its reversal; the preparation of insoluble globin, soluble globin and heme. F. gen. Physiol., 13, 469.

Askonas, B. A., and Smyth, D. G. (1964). Antigenicity of the $\beta$-chain of human haemoglobin. Nature (Lond.), 201, 496.

Atwater, J., Huehns, E. R., and Shooter, E. M. (196I). Haemoglobin $I_{2}$, a further variant of haemoglobin $A_{2}$. F. molec. Biol., 3, 707.
Schwartz, I. R., Erslev, A. J., Montgomery, T. L., and Tocantins, L. M. (1960a). Sickling of erythrocytes in a patient with thalassemia-hemoglobin-I disease. New Engl. f. Med., 263, 1215.

, - and Tocantins, L. M. (1960b). A variety of human hemoglobin with 4 distinct electrophoretic components. Blood, I5, 901 .

Babin, D. R., Jones, R. T., and Schroeder, W. A. (1964). Haemoglobin $\mathrm{D}_{\text {Los }} \mathrm{Angeles} \alpha_{2}^{\mathrm{A}} \beta_{2}^{i 21} \mathrm{GluNH}_{2}$. Biochim. biophys. Acta (Amst.), 86, 136 .

Bachmann, F., and Marti, H. R. (r962). Hemoglobin Zürich. II. Physicochemical properties of the abnormal hemoglobin. Blood, 20, 272.

Baglioni, C. (196r). An improved method for the fingerprinting of human hemoglobin. Biochim. biophys. Acta (Amst.), 48, 392.

- (1962a). Abnormal human haemoglobins. VIII. Chemical studies on haemoglobin D. ibid., 59, 437.

(1962b). The fusion of two peptide chains in hemoglobin Lepore and its interpretation as a genetic deletion. Proc. nat. Acad. Sci. (Wash.), 48, 1880 .

- (1962c). A chemical study of hemoglobin Norfolk. F. biol. Chem., 237, 69.

(1963a). Correlations between genetics and chemistry of human hemoglobins. In Molecular Genetics, ed. J. H. Taylor, Pt. I, p. 405. Academic Press, New York.

(I963b). A child homozygous for persistence of fetal haemoglobin. Nature (Lond.), 198, 177.

, and Ingram, V. M. (1961). Abnormal human haemoglobins. V. Clinical investigation of haemoglobins A, G, C, X from one individual. Biochim. biophys. Acta (Amst.), 48, 253.

- and Lehmann, H. (1962). Chemical heterogeneity of haemo- N globin O. Nature (Lond.), 196, 229.

, and Weatherall, D. J. (1963). Abnormal human hemoglobins. IX. Chemistry of hemoglobin J Baltimore. Biochim. biophys. Acta (Amst.), 78, 637.

Bannerman, R. M. (1961). Thalassemia-A Survey of Some Aspects. Grune and Stratton, New York.

-, Grinstein, M., and Moore, C. V. (1959). Haemoglobin synthesis in thalassaemia; in-vitro studies. Brit. F. Haemat., $5,102$.

Barkhan, P., and Adinolf, M. (1962). Observations on the high foetal haemoglobin gene and its interaction with the thalassaemia gene. F. clin. Path., 15, 350. 
- , Stevenson, M. E., Pinker, G., Dance, N., and Shooter, E. M. (I964). Haemoglobin Lepore trait: an analysis of the abnormal haemoglobin. Brit. F. Haemat., ro, 437.

Barnabas, J., and Muller, C. J. (1962). Haemoglobin-

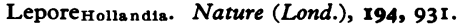

Barnicot, N. A., Allison, A. C., Blumberg, B. S., Deliyannis, G., Krimbas, C., and Ballas, A. (1963). Haemoglobin types in Greek populations. Ann. hum. Genet., 26, 229.

Bayrakci, C., Josephson, A., Singer, L., Heller, P., and Coleman, R. D. (1964). A new fast haemoglobin. Proc. int. Soc. Haemat., Io. In the press.

Beale, D., and Lehmann, H. (1964). Haemoglobin Joxford. Biochem. $\mathcal{F}$, 93, 8.

Beaven, G. H., Ellis, M. J., and White, J. C. (1960a). Studies on human foetal haemoglobin. I. Detection and estimation. Brit. F. Haemat., 6, 1 .

$\longrightarrow$, and - (1960b). Studies on human foetal haemoglobin. II. Foetal haemoglobin levels in healthy children and adults and in certain haemotological disorders. ibid., 6, 201.

- and Gratzer, W. B. (1959). A critical review of human haemoglobin variants. $f$. clin. Path., 12, I, ror.

J, - Stevens, B. L., Shooter, E. M., Ellis, M. J., White, J. C., and Gillespie, J. E. O'N. (r964). An abnormal haemoglobin (Lepore/Cyprus) resembling haemoglobin-Lepore and its interaction with thalassaemia. Brit. F. Haemat., 10, 159.

- Stevens, B. L., Dance, N., and White, J. C. (I963). Occurrence of haemoglobin $\mathrm{H}$ in leukaemia. Nature (Lond.), 199, 1297.

Beet, E. A. (1949). Genetics of the sickle-cell trait in a Bantu tribe. Ann. Eugen. (Lond.), I4, 279.

Benzer, S., Ingram, V. M., and Lehmann, H. (1958). Three varieties of human haemoglobin D. Nature (Lond.), 182, 852.

Bergren, W. R., and Sturgeon, P. (I960). Hemoglobin H. Some additional findings. Proc. int. Soc. Haemat., 7, (2), part 1, 488.

Betke, K., Marti, H. R., and Schlicht, I. (1959). Estimation of small percentages of foetal haemoglobin. Nature (Lond.), 184, 1877 .

Bianco, I., Modiano, G., Bottini, E., and Lucci, R. (1963). Alteration in the $\alpha$-chain of haemoglobin LFerrara. ibid., r98, 395.

Bingle, J. P., Huehns, E. R., and Prankerd, T. A. J. (1958). Haemoglobin-H disease. Brit. med. f., 2, 1389.

Bird, G. W. G., and Lehmann, H. (1956). Haemoglobin D in India. ibid., 1,514 .

Bishop, J., Leahy, J., and Schweet, R. (1960). Formation of the peptide chain of hemoglobin. Proc. nat. Acad. Sci. (Wash.), 46, 1030.

Boulard, C., Cosset, A., Destaing, F., Duzer, A., Jonxis, J. H. P., Muller, C. J., and Portier, A. (I96r). Hb I trait in an Algerian Mussulman family, presenting two abnormal components. Blood, 18, 750.

Bowman, B. H., Oliver, C. P., Barnett, D. R., Cunningham, J. E., and Schneider, R. G. (1964). Chemical characterization of three hemoglobins G. ibid., 23, 193 .

Boyer, S. H., Rucknagel, D. L., Weatherall, D. J., and WatsonWilliams, E. J. (1963). Further evidence for linkage between the $\beta$ and $\delta$ loci governing human hemoglobin and the population dynamics of linked genes. Amer. F. hum. Genet., I5, 438.

Bradley, T. B., Jr., Brawner, J. N., III, and Conley, C. L. (I96r). Further observations on an inherited anomaly characterized by persistence of fetal hemoglobin. Bull. Fohns Hopk. Hosp., 108, 242.

Braunitzer, G., Gehring-Müller, G., Hilschmann, N., Hilse, K., Hobom, G., Rudloff, V., and Wittmann-Liebold, B. (r96r). Die Konstitution des normalen adulten Humanhămoglobins. Hoppe-Seylers Z. physiol. Chem., 325, 283.

Bridges, J. M., Neill, D. W., and Lehmann, H. (I96r). Increase in $\mathrm{Hb}-\mathrm{A}_{2}$ appearing after homograft of foetal haemopoietic tissue. Brit. med. F., I, 1349.

Bromberg, Y. M., Salzberger, M., and Abrahamov, A. (1957). Alkali resistant type of hemoglobin in women with molar pregnancy. Blood, 12, 1122.

Burnham, B. F., and Lascelles, J. (1963). Control of porphyrin biosynthesis through a negative-feedback mechanism. Studies with preparations of $\delta$-aminolaevulate synthetase and 8 aminolaevulate dehydratase from Rhodopseudomonas spheroides. Biochem. F., 87, 462

Ceppelini, R. (1959). In Ciba Foundation Symposium on Biochemistry of Human Genetics, p. 133, eds G. E. W. Wolstenholme and C. M. O'Connor. Churchill, London.
Chernoff, A. I. (1953a). Immunologic studies of hemoglobins. I. The production of antihemoglobin sera and their immunologic characteristics. Blood, 8, 399.

- (1953b). Immunologic studies of hemoglobins. II. Quantitative precipitin test using anti-fetal hemoglobin sera. ibid., 8, 413.

(196I). Chromium-5I tagging of the $\alpha$-chain of human haemoglobin. Nature (Lond.), r92, 327.

- (1964). Hb-A . A naturally occurring hemoglobin possessing only $\alpha$-chains. Proc. int. Soc. Haemat., ro. In the press.

- and Liu, J. C. (I96I). The amino acid composition of hemoglobin. II. Analytical technics. Blood, 17, 54 .

, and Perillie, P. E. (1964). The amino acid composition of Hgb New Haven 2 (Hgb N New Haven). Biochem. biophys. Res. Commun., 16, 368.

Clegg, M. D., and Schroeder, W. A. (1959). A chromatographic study of the minor components of normal adult human hemoglobin, including a comparison of hemoglobin from normal and phenylketonuric individuals. f. Amer. chem. Soc., 81, 6065.

Conley, C. L., Weatherall, D. J., Richardson, S. N., Shepard, M. K., and Charache, S. (1963). Hereditary persistence of fetal hemoglobin: a study of 79 affected persons in 15 negro families in Baltimore. Blood, 21, 26r.

Crick, F. H. C., Barnett, L., Brenner, S., and Watts-Tobin, R. J. (196I). General nature of the genetic code for proteins. Nature (Lond.), 192, 1227.

Cullis, A. F., Muirhead, H., Perutz, M. F., Rossmann, M. G., and North, A. C. T. (I962). The structure of hemoglobin. IX. A three-dimensional Fourier synthesis at $5.5 \AA$ resolution: description of the structure. Proc. roy. Soc. Lond., Series A, 265, I6I.

Dacie, J. V., Grimes, A. J., Meisler, A., Steingold, L., Hemsted, E. H., Beaven, G. H., and White, J. C. (1964). Hereditary Heinz-body anaemia: a report of studies on five patients with mild anaemia. Brit. f. Haemat., 10, 388.

Dance, N., and Huehns, E. R. (1962). A haemoglobin containing only 8 -chains. Biochem. biophys. Res. Commun., 7, 444.

$\longrightarrow$, and Beaven, G. H. (1963). The abnormal haemoglobins in haemoglobin-H disease. Biochem. $\mathcal{F}, \mathbf{8 7}, 240$.

, - , and Shooter, E. M. (1964). The chemical investiga-

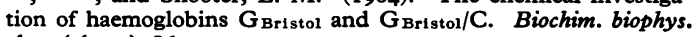
Acta (Amst.), 86, 144.

De Vries, A., Joshua, H., Lehmann, H., Hill, R. L., and Fellow, R. E. (r963). The first observation of an abnormal haemoglobin in a Jewish family: haemoglobin Beilinson. Brit. F. Haemat., 9, 484

Diggs, L. W., and Bibb, J. (1939). The erythrocyte in sickle cell anemia. F. Amer. med. Ass., I12, 695.

Dintzis, H. M. (196r). Assembly of peptide chains of hemoglobin. Proc. nat. Acad. Sci. (Wash.), 47, 247.

Dormandy, K. M., Lock, S. P., and Lehmann, H. (196r). Haemoglobin Q-alpha-thalassaemia. Brit. med. F., I, 1582.

Drabkin, D. L., and Wise, C. D. (1962). Creation of a crystalline interspecies hybrid of hemoglobin at $\mathrm{pH}$ close to neutrality. f. biol. Chem., 237, $26 \mathrm{r}$.

Drescher, H., and Künzer, W. (1954). Der Blutfarbstoff des menschlichen Feten. Klin. Wschr., 32, 92.

Edington, G. M., and Lehmann, H. (1955a). Expression of the sickle-cell gene in Africa. Brit. med. $\mathcal{F}$., $1,1308$.

, and - (r955b). Expression of the sickle-cell gene in Africa. ibid., 2, 1328.

$\longrightarrow$, and Watson-Williams, E. J. (1964). Sickling, haemoglobin C, glucose-6-phosphate dehydrogenase deficiency and malaria in Western Nigeria. C.I.O.M.S. Symposium on Abnormal Haemoglobins and Enzyme Deficiency. Blackwell, Oxford. In the press.

Fessas, P. (1960). Observations on a second haemoglobin abnormality in haemoglobin-H disease. Proc. 7 th Congr. europ. Soc. Haemat., part II, 1043.

(1962). Haemoglobin $\mathbf{H}$ and Bart's. In Haemoglobin Colloquium, Vienna, I96r, ed. H. Lehmann and K. Betke, p. 74. Thieme, Stuttgart.

(1964). Forms of thalassaemia. In C.I.O.M.S. Symposium on Abnormal Haemoglobins and Enzyme Deficiency. Blackwell, Oxford. In the press.

- Karaklis, A., and Gnafakis, N. (196r). A further abnormality of foetal haemoglobin. Acta Haemat. (Basel), $25,62$.

, and Loukopoulos, D. (I964). Alpha-chain of human hemoglobin: occurrence in vivo. Science, 143, 590. 
-, Mastrokalos, N., and Fostiropoulos, G. (1959). New variant of human foetal haemoglobin. Nature (Lond.), 183, 30.

, and Papaspyrou, A. (1957). New 'fast' hemoglobin associated with thalassemia. Science, 126, 1119.

, and Stamatoyannopoulos, G. (1962). Absence of haemoglobin $A_{2}$ in an adult. Nature (Lond.), 195, 1215.

, and - (1964). Hereditary persistence of fetal hemoglobin in Greece. A study and a comparison. Blood, 24, 223.

$\longrightarrow,-$, and Karaklis, A. (1962). Hemoglobin 'Pylos': study of a hemoglobinopathy resembling thalassemia in the heterozygous, homozygous and double heterozygous state. ibid., 19, 1 .

Frick, P. G., Hitzig, W. H., and Betke, K. (1962). Hemoglobin Zürich. I. A new hemoglobin anomaly associated with acute hemolytic episodes with inclusion bodies after sulfonamide therapy. ibid., 20, $26 \mathrm{r}$.

Gammack, D. B., Huehns, E. R. Lehmann, H., and Shooter, E. M. (196I). The abnormal polypeptide chains in a number of haemoglobin variants. Acta Genet. (Basel), II, I.

,-- Shooter, E. M., and Gerald, P. S. (1960). Identification of the abnormal polypeptide chain of hemoglobin $\mathrm{G}_{\mathrm{Ib}}$. F. molec. Biol., 2, 372.

Gerald, P. S. (1958). The electrophoretic and spectroscopic characterization of $\mathrm{Hgb}$ M. Blood, 13, 936.

- and Diamond, L. K. (1958a). The diagnosis of thalassemia trait by starch block electrophoresis of the hemoglobin. ibid., r3, 6r.

13, and - (1958b). A new hereditary hemoglobinopathy (the Lepore trait) and its interaction with thalassemia trait. ibid., 13, 835 .

, and Efron, M. L. (196r). Chemical studies of several varieties of Hb. M. Proc. nat. Acad. Sci. (Wash.), 47, 1758.

-, and George, P. (1959). Second spectroscopically abnormal methemoglobin associated with hereditary cyanosis. Science, 129, 393.

-, and Ingram, V. M. (196I). Recommendations for the nomenclature of hemoglobins. F. biol. Chem., 236, 2155.

Gibson, Q. H. (1948). Reduction in methaemoglobin in red blood cells and studies on the cause of idiopathic methaemoglobinaemia. Biochem. F., 42, 13.

Gottlieb, A. J., Restrepo, A., and Itano, H. A. (I964). Hb J Jedellin. Chemical and genetic study. Fed. Proc., 23, 172.

Gouttas, A., Fessas, P., Tsevrenis, H., and Xefteri, E. (1955). Description d'une nouvelle variété d'anémie hémolytique congénitale: étude hématologique électrophorétique et génétique. Sang, 26, 911 .

Gray, S. J., and Sterling, K. (1950). The tagging of red cells and plasma proteins with radioactive chromium. f. clin. Invest., 29, 1604 .

Griggs, R. C., and Harris, J. W. (1955). The biophysics of the variants of sickle cell disease. ibid., 34, 937.

Grimes, A. J., and Meisler, A. (I962). Possible cause of Heinz bodies in congenital Heinz-body anaemia. Nature (Lond.), 194, 190.

194, 190., and Dacie, J. V. (1964). Congenital Heinz-body anaemia: further evidence on the cause of Heinz-body production in red cells. Brit. F. Haemat., 10, $28 \mathrm{r}$.

Guidotti, G., Konigsberg, W., and Craig, L. C. (1963). On the dissociation of normal adult human hemoglobin. Proc. nat. Acad. Sci. (Wash.), 50, 774.

Hahn, E. V., and Gillespie, E. B. (1927). Sickle cell anemia: a report of a case greatly improved by splenectomy. Arch. intern. Med., 39, 233.

Haldane, J. B. S. (1949). Disease and evolution. La Ricerca Scientif. (suppl.), 19, 68.

Hall-Craggs, M., Marsden, P. D., Raper, A. B., Lehmann, H. and Beale, D. (1964). Homozygous sickle-cell anaemia arising from two different haemoglobins S. Interaction of haemoglobin $S$ and Stanleyville-II. Brit. med. f., 2, 87.

Ham, T. H., and Castle, W. B. (1940). Relation of increased hypotonic fragility and of erythrostasis to the mechanism of hemolysis in certain anemias. Trans. Ass. Amer. Phycns, 55, 127.

Hamilton, H. E., Sheets, R. F., and Brosseau, G. (1962). Gamma thalassemia. F. Lab. clin. Med., 60, 880.

Hanada, M., and Rucknagel, D. L. (1963). The abnormality of the primary structure of hemoglobin Shimonoseki. Biochem. biophys. Res. Commun., 11, 229.
Harris, J. W., Brewster, H. H., Ham, T. H., and Castle, W. B. (D (1956). Studies on the destruction of red blood cells. $X$. The $\overparen{\mathbb{D}}$ biophysics and biology of sickle-cell disease. Arch. int. Med., $\stackrel{\mathbb{P}}{?}$

Hayashi, H. (196r). A simple method for the fractionation of globins into their $\alpha$ - and $\beta$-chains. F. Biochem. (Tokyo), 50, 70.

Heck, W., and Wolf, H. (1958). Angeborener Herzfehler mit Cyanose durch pathologischen Blutfarbstoff (Hämoglobin $M$ ). 음 Ann. paediat. (Basel), 190, 135.

Heisterkamp, D., and Ebaugh, F. G., Jr. (1962). Site of attachment $\frac{\hbar}{\partial}$ of the chromate ion to the haemoglobin molecule. Nature (Lond.), 193, 1253.

Heller, P., Weinstein, H. G., Yakulis, V. J., and Rosenthal, I. M. ڤ) (I962b). Haemoglobin M Manka kee, a new variant of haemoglobin $\overrightarrow{-}$ M. Blood, 20, 287.

, Yakulis, V. J., Epstein, R. B., and Friedland, S. (I963). $\rightarrow$ Variation in the amount of hemoglobin $S$ in a patient with sickle $\vec{\omega}$ cell trait and megaloblastic anemia. ibid., 21, 479.

,-- , and Josephson, A. M. (1962a). Immunologic studies of human hemoglobins. F. Lab. clin. Med., 59, 401.

Herman, E. C., Jr., and Conley, C. L. (1960). Hereditary persis-ĩ tence of fetal hemoglobin. A family study. Amer. F. Med., 29, 9.

Hill, R. J., and Craig, L. C. (1959). Countercurrent distribution studies with adult human hemoglobin. F. Amer. chem. Soc., 81, $\infty$ 2272. 2272.
of and Kraus, A. P. (1963). Studies on the amino acid sequence $\frac{O}{\triangle}$
of A $_{2}$. Fed. Proc., 22, 597.

Hill, R. L. (196I). The abnormal human hemoglobins. Lab.

Invest., 10, IOI2. of a chemical abnormality in hemoglobin G. F. biol. Chem.,

235, 3182.
Holmquist, W. R., and Schroeder, W. A. (1964). Properties and $\overrightarrow{\mathscr{G}}$ partial characterization of adult hemoglobin AIc. Biochim. G biophys Acta (Amst.), 82, 639.

Hörlein, H., and Weber, G. (1948). Über chronische familiäre Methämoglobinämie und eine neue Modifikation des Methämoglobin. Dtsch. med. Wschr., 73, 476. , and - (I95I). Chronische familiäre Methämoglobinämie. $\bar{O}$ Z. ges. inn. Med., 6, 197.

Horton, B., Payne, R. A., Bridges, M. T., and Huisman, T. H. J. 을 (196I). Studies on an abnormal minor hemoglobin componente $\left(\mathrm{Hb}-\mathrm{B}_{2}\right)$. Clin. chim. Acta, 6, 246.

Horton, B. F., and Huisman, T. H. J. (1963). Linkage of the $\beta$-chain and $\delta$-chain structural genes of human hemoglobins. 3 Amer. F. hum. Genet., 15, 394.

Huehns, E. R. (1962). Haemoglobin H Disease. Clinical and Experi mental Studies. M.D. Thesis, University of London.

$\longrightarrow$, Beaven, G. H., and Stevens, B. L. (1964e). Reaction of haemoglobin $\alpha^{\mathrm{A}}$ with haemoglobins $\beta_{+}^{\mathrm{A}}, \gamma_{+}^{\mathrm{F}}$, and $\delta^{\mathrm{A}}{ }_{2}$. Biochem. F.

92, 444. globins at neutral pH. ibid., $92,440$.

, Dance, N., Beaven, G. H. Hecht, F., and Motulsky, A. G.'ं (1964b). Human embryonic haemoglobins. Cold Spr. Harb. O근 Symp. quant. Biol., 29. In the press.

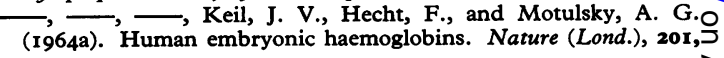
1095.

preparation and properties of haemoglobin $\alpha^{\mathrm{A}}$, a haemoglobin consisting of $\alpha^{A}$-polypeptide chains. F. molec. Biol., 5, 511 . $N$ , Flynn, F. V., Butler, E. A., and Beaven, G. H. (r96ra). Two new haemoglobin variants in a very young human embryo.N Nature (Lond.), 189, 496.

$\longrightarrow,-$, and Shooter, E. M. (1960). The occurrence of haemoglobin 'Bart's' in conjunction with haemoglobin H. Brit.
f. Haemat., 6, 388.

1. Hecht, F., Keil, J. V., and Motulsky, A. G. (1964c). DetO velopmental hemoglobin anomalies in a chromosomal triplication: $\mathrm{D}_{1}$ trisomy syndrome. Proc. nat. Acid. Sci. (Wash.), 51, 89.

, and Shooter, E. M. (196ra). Polypeptide chains of haemo-? globin $\mathrm{A}_{2}$. Nature (Lond.), 189, 918.

, and $-(196 \mathrm{Ib})$. The polypeptide chains of haemoglobin- $-\bar{O}$ $A_{2}$ and haemoglobin- $G_{2}$. F. molec. Biol., 3, 257.

, and - (1962). Reaction of haemoglobin $\alpha^{A}$ with haemo- $\subseteq$ globin H. Nature (Lond.), 193, 1083. 
- , and - (1964a). Haemoglobin. Sci. Progr., 52, 353.

, and (1964b). The subunits of haemoglobins. Ist Meeting of the Federation of European Biochemical Societies, London. I964 Symposium. The Structure and Activity of Enzymes. 167.

- - - and Beaven, G. H. (I962a). On the recombination of canine and human haemoglobins. F. molec. Biol., 4, 323

$\longrightarrow$, and - (I964d). The time course of the recombination of human adult and canine haemoglobins. Biochem. F., 91, 331.

- Dance, N., Beaven, G. H., and Shooter, K. V. (196rb) Haemoglobin $\alpha^{\mathbf{A}}$. Nature (Lond.), 192, 1057.

Huisman, T. H. J. (1960). Genetic aspects of two different minor haemoglobin components found in cord blood samples of Negro babies. ibid., 188, 589 .

- (1962). A new alpha chain-abnormal hemoglobin in a white family. In Haemoglobin Colloquium, Vienna 196r, ed. H. Lehmann and K. Betke, p. 37. Thieme, Stuttgart.

-, and Dozy, A. M. (I962). Studies on the heterogeneity of hemoglobin. IV. Chromatographic behaviour of different human haemoglobins on anion-exchange cellulose (DEAE cellulose) f. Chromatog., 7, 180 .

-, Martis, E. A., and Dozy, A. (1958). Chromatography of hemoglobin types of carboxymethylcellulose. f. Lab. clin. Med., 52, 312.

, and Meyering, C. A. (1960). Studies on the heterogeneity of hemoglobin. I. The heterogeneity of different human hemoglobin types in carboxymethylcellulose and in Amberlite IRC-50 chromatography: qualitative aspects. Clin. chim. Acta, 5, 103.

- and Prins, H. K. (1955). Chromatographic estimation of four different human hemoglobins. f. Lab. clin. Med., 46, 255.

associated with hemoglobin-B, heterozygosity. A family report. Blood, 17, 747.

of two electrophoretically identical 'minor' haemoglobin components. Nature (Lond.), 193, 489.

Hunt, J. A. (1959). Identity of the $\alpha$-chains of adult and foetal human haemoglobins. ibid., $183,1373$.

- and Ingram, V. M. (1958). Abnormal human haemoglobins. II. The chymotryptic digestion of the trypsin-resistant 'core' of haemoglobins A and S. Biochim. biophys. Acta (Amst.), 28, 546. - and - (1960). Abnormal human haemoglobins. IV. The chemical difference between normal human haemoglobin and haemoglobin C. ibid., 42, 409.

, and - (I96I). Abnormal human haemoglobins. VI. The chemical difference between haemoglobins $\mathrm{A}$ and E. ibid., 49, 520.

- , and Lehmann, H. (1959). Haemoglobin 'Bart's': a foetal haemoglobin without $\alpha$-chains. Nature (Lond.), 184, 872.

Hutchison, H. E., Pinkerton, P. H., Waters, P., Douglas, A. S., Lehmann, H., and Beale, D. (I964). Hereditary Heinz-body anaemia, thrombocytopenia, and haemoglobinopathy (Hb Köln) in a Glasgow family. Brit. med. F., 2, 1099.

Hynes, M., and Lehmann, H. (I956). Haemoglobin D in a Persian girl: presumably the first case of haemoglobin-D-thalassaemia. ibid., 2, 923.

Ingram, V. M. (1956). A specific chemical difference between the globins of normal human and sickle-cell anaemia haemoglobin. Nature (Lond.), 178, 792.

- (1958). Abnormal human haemoglobins. I. The comparison of normal human and sickle-cell haemoglobins by 'fingerprinting'. Biochim. biophys. Acta (Amst.), 28, 539.

- (1959). Separation of the peptide chains of human globin. Nature (Lond.), 183, 1795.

(1961). Hemoglobin and its Abnormalities. Charles C. Thomas, Springfield, Illinois.

(1964). A molecular model for thalassaemia. Ann. N.Y. Acad. Sci. In the press.

, and Stretton, A. O. W. (1959). Genetic basis of the thalassemia diseases. ibid., 184, 1903 .

$\longrightarrow$, and Stretton, A.O.W. (I96I). Human haemoglobin $\mathbf{A}_{2}$ : chemistry, genetics and evolution. ibid., 190, 1079.

$\longrightarrow$, and - (1962a). Human haemoglobin $A_{2}$. I. Comparison of haemoglobins $\mathrm{A}_{2}$ and A. Biochim. biophys. Acta (Amst.), $62,456$.

, and - (1962b). Human haemoglobin $A_{2}$. II. The chemistry of some peptides peculiar to haemoglobin $A_{2}$. ibid., 63, 20.
Itano, H. A. (I953). Qualitative and quantitative control of adult hemoglobin synthesis-a multiple allele hypothesis. Amer. $\mathfrak{F}$. hum. Genet., 5, 34 .

- (1957). The human hemoglobins: their properties and genetic control. Advanc. Protein Chem., 12, 215.

- (1964). The synthesis and structure of normal and abnormal hemoglobins. In C.I.O.M.S. Symposium on Abnormal Haemoglobins and Enzyme Deficiency. Blackwell, Oxford. In the press.

, Bergren, W. R., and Sturgeon, P. (1956). The abnormal human hemoglobins. Medicine (Baltimore), 35, I21.

, and Robinson, E. (1959). Properties and inheritance of haemoglobin by asymmetric recombination. Nature (Lond.), 184, 1468. , and - (1960). Genetic control of the $\alpha$ - and $\beta$-chains of hemoglobin. Proc. nat. Acad. Sci. (Wash.), 46, 1492.

- , and Singer, S. J. (1958). Dissociation and recombination of human adult hemoglobins $\mathrm{A}, \mathrm{S}$ and $\mathrm{C}$. ibid., 44, 522 .

- — a a Robinson, E. (1959). Abnormal and genetical units of the haemoglobin molecule. In Ciba Found. Symp. Biochemistry of Human Genetics, ed. G. E. W. Wolstenholme and C. M. O'Connor, p. 96 . Churchill, London.

Jaffe, E. R., and Heller, P. (1964). Methemoglobinemia in man. Progr. Hemat., 4, 48.

Jacob, F., and Monod, J. (I96I). Genetic regulatory mechanisms in the synthesis of proteins. $\mathcal{F}$. Mole. Biol., 3, 318 .

Jacob, G. F., and Raper, A. B. (1958). Hereditary persistence of foetal haemoglobin production, and its interaction with the sicklecell trait. Brit. f. Haemat., 4, 138.

Jones, J. H. (1961). Foetal haemoglobin in Fanconi type anaemia. Nature (Lond.), $192,982$.

Jones, R. T. (I964). Structural studies of amino ethylated hemoglobins by automatic peptide chromatography. Cold Spr. Harb. Symp.Quant. Biol., 29. In the press.

-, Coleman, R. D., and Heller, P. (1964). The chemical struct-

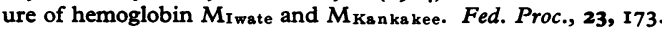
, Koler, R. D., and Lisker, R. (1963). The chemical structure of hemoglobin Mexico determined by automatic peptide chromatography and subunit hybridization. Clin. Res., I1, ro5.

, and Schroeder, W. A. (1963). Chromatography of human hemoglobin. Factors influencing chromatography and differentiation of similar hemoglobins. $\mathcal{F}$. Chromat., 10, 421 .

-, Balog, J. E., and Vinograd, J. R. (1959). Gross structure of hemoglobin H. F. Amer. chem. Soc., 8r, 3161 .

Jonxis, J. H. P. (195I). Personal communication. In The Physiology of the Newborn Infant, by C. A. Smith, and ed., p. 9. Blackwell, Oxford.

- (I96r). Uber hämoglobinopathien mit besonderer Berücksichtigung der Cooley-Anämie. Schweiz. med. Wschr., 91, 1037. (1963). Hemoglobinopathies. Ann. Rev. Med., r4, 297.

Jope, E. M. (1949). The ultraviolet spectral absorption of haemoglobin inside and outside the red blood cell. In Haemoglobin (Barcroft Memorial Conference), ed. F. J. W. Roughton and J. C. Kendrew, p. 205. Butterworth, London.

Josephson, A. M., Masri, M. S., Singer, L., Dworkin, D., and Singer, K. (1958). Starch block electrophoretic studies of human hemoglobin solutions. II. Results in cord blood, thalassemia and other hematologic disorders: comparison with Tiselius electrophoresis. Blood, 13, 543.

, Weinstein, H. G., Yakulis, V. J., Singer, L., and Heller, P. (I962). A new variant of hemoglobin $M$ disease: hemoglobin Mchicago. F. Lab. clin. Med., 59, 918 .

Karaklis, A., and Fessas, P. (1963). Normal minor components of human foetal haemoglobin. Acta haemat. (Basel), 29, 267.

Kekwick, R. A., and Lehmann, H. (1960). Sedimentation characteristics of the $\gamma$-chain haemoglobin (haemoglobin 'Bart's'). Nature (Lond.), $187,158$.

Kochhar, B. R., and Kathpalia, P. M. L. (1963). Hemoglobin Ethalassaemia disease. Indian $\mathcal{f}$. med. Sci., 17, 138 .

Konigsberg, W., and Hill, R. J. (1962). The structure of human hemoglobin. III. The sequence of amino acids in the tryptic peptides of the $\alpha$-chain. $\mathcal{F}$. biol. Chem., 237, 2547.

Körber, E. (1866). Ueber Differenzen des Blutfarbstoffe. Inaugural Dissertation, Dorpat, cited by J. C. White and G. H. Beaven (1959). Brit. med. Bull., 15, 33.

Kraus, A. P., Koch, B., and Burckett, L. (I96I). Two families showing interaction of haemoglobin $C$ or thalassaemia with high foetal haemoglobin in adults. Brit. med. $\mathcal{F}$., 1,1434 
Kruatrachue, M., Na-Nakorn, S., Charoenlarp, P., and Suwanakul, L. (r $96 \mathrm{r}$ ). Haemoglobin $\mathrm{E}$ and malaria in south-east Thailand. Ann. trop. Med. Parasit., 55, 468.

Kunkel, H. G. (1954). Zone electrophoresis. Meth. biochem. Anal., p. I4I.

$\longrightarrow$, and Bearn, A. G. (1957). Minor hemoglobin components of normal human blood. Fed. Proc., 16, 760.

- Ceppellini, R., Müller-Eberhard, U., and Wolf, J. (1957). Observations on the minor basic hemoglobin component in the blood of normal individuals and patients with thalassemia. $\mathcal{f}$. clin. Invest., 36, I6I5.

blood. Science, 122, 288.

Labie, D., Rosa, J., Dreyfus, J.C., and Shapira, G. (1962). Interspecific hybridization of haemoglobin. Nature (Lond.), 194, 384

Lambotte-Legrande, J., and Lambotte-Legrande, C. (1958). Notes complémentaires sur la drépanocytose. II. Sicklémie et anémie par ankylostomiase. Ann. Soc. belge Méd. trop., 38, 55.

Lange, R. D., and Akeroyd, J. H. (1958). Congenital hemolytic anemia with abnormal pigment metabolism and red cell inclusion bodies: a new clinical syndrome. Blood, 13, 950.

-, Minnich, V., and Moore, C. V. (195I). Effect of oxygen tension and of $\mathrm{pH}$ on the sickling and mechanical fragility of erythrocytes from patients with sickle cell anemia and sickle cell trait. f. Lab. clin. Med., 37, 789 .

Lascelles, J. (1960). The synthesis of enzymes concerned in bacteriochlorophyll formation in growing cultures of Rhodopseudomonas spheroides. F. gen. Microbiol., 23, 487.

Lehmann, H. (I960). The laboratory detection of abnormal haemoglobins. Ass. clin. Path. Broadsheets No. 27.

- , and Ager, J. A. M. (1960). The Metabolic Basis of Inherited Disease, p. ro86. McGraw-Hill, New York.

, Beale, D., and Boi-Doku, F. S. (1964). Haemoglobin $\mathrm{G}_{\text {Acera. }}$ Nature (Lond.), 203, 363.

- Story, P., and Thein, H. (1956). Haemoglobin E in Burmese. Two cases of haemoglobin E disease. Brit. med. $\mathcal{F}$., 1,544

Levin, W. C. (1958). 'Asymptomatic' sickle cell trait. Blood, r3, 904.

Lie-Injo Luan Eng (196r) Haemoglobin 'Bart's' and the sickling phenomenon. Nature (Lond.), 191, 1314.

- (1962). Alpha-chain thalassemia and hydrops fetalis in Malaya: report of five cases. Blood, $20,58 \mathrm{I}$.

(1964). Haenozlobinopathies in East Asia. Ann. hum. Genet., 28, ror.

- and Hart, P. L. de V. (1963). Splenectomy in two cases of haemoglobin Q-H-disease (Hb Q- $\alpha$-thalassaemia). Acta haemat. (Basel), 29, 358.

- , and Jo Bwan Hie (1960). Hydrops foetalis with a fast-moving haemoglobin. Brit. med. $\mathcal{F} ., 2,1649$.

- , and Lie Hong Gie (196I). Abnormal haemoglobin production as a probable cause of erythroblastosis and hydrops foetalis in uniovular twins. Acta haemat. (Basel), 25, 192.

Livingstone, F. B. (1958). Anthropological implications of sickle cell gene distribution in West Africa. Amer. Anthrop., 60, 633 .

London, I. (1964). The synthesis of haemoglobin. Proc. Int. Soc. Haemat., 10. In the press.

Malamos, B., Fessas, P., and Stamatoyannopoulos, G. (1962). Types of thalassaemia-trait carriers as revealed by a study of their incidence in Greece. Brit. $\mathcal{F}$. Haemat., 8, 5 .

Malcolm, D., Ranney, H. M., and Jacobs, A. S. (1963). Association of radioactive chromium with various components of hemoglobin. Blood, $21,8$.

Marks, P. A., and Burka, E. R. (1964). Hemoglobin A and F: formation in thalassemia and other hemolytic anemias. Science, I44, 552.

Marti, H. R. (1963). Normale and anomale menschliche Hämoglobine, p. 85. Springer, Berlin

, and Bütler, R. (196r). Hämoglobin F-und hämoglobin $A_{2}$ Vermehrung bei der Schweizer Bevölkerung. Acta haemat. (Basel), 26, 65.

Mathur, K. S., and Misra, G. M. (1962). An unstable haemoglobin associated with myeloid leukaemia (a case report). f. Ass. Phycns India, 10, 225.

Meyering, C. A., Israels, A. L. M., Sebens, T., and Huisman, T. H. J. (1960). Studies on the heterogeneity of hemoglobin. II. The heterogeneity of different human hemoglobin types in carboxymethylcellulose and in Amberlite IRC-50 chromatography: quantitative aspects. Clin. chim. Acta, 5, 208.
Minnich, V., Cordonnier, J. K., Williams, W. J., and Moore, C. V. (1962). Alpha, beta and gamma hemoglobin polypeptide chains during the neonatal period with description of a fetal form of hemoglobin $\mathrm{D} \alpha$ st. Lou1s. Blood, 19, 137.

- , Na-Nakorn, S., Tuchinda, S., Pravit, W., and Moore, C. V. (1956). Inclusion body anemia in Thailand (Hemoglobin Hthalassemia disease). Proc. 6th Congr. Int. Soc. Hemat., 743.

Miyaji, T., Iuchi, I., Shibata, S., Takeda, I., and Tamura, A. (1963a). Possible amino acid substitution in the $\alpha$-chain ( $\alpha 87 \mathrm{Tyr}$ )

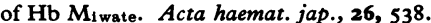

$\longrightarrow$ - - Takeda, I., and Shibata, S. (1963b). Haemoglobin Shimonoseki $\left(\alpha_{2}^{5+A r g} \beta_{2}^{A}\right)$, a slow-moving hemoglobin found in a Japanese family, with special reference to its chemistry. ibid., 26, 531 .

Moore, M. M., and Pearson, H. A. (1964). Human hemoglobin gene linkage with an apparent crossing over between thalassemia and delta loci. Clin. Res., 12, 34.

Motulsky, A. G. (1962). Controller genes in synthesis of human haemoglobin. Nature (Lond.), 194, 607.

(I964a). Hereditary red cell traits and malaria. Amer. $f$. trop. Med. Hyg., I3, 147.

- (1964b). Thalassaemia. Cold Spr. Harb. Symp. quant. Biol., 29 , In the press.

Muirhead, H., and Perutz, M. F. (1963). Structure of haemoglobin. A three-dimensional Fourier synthesis of reduced human haemoglobin at 5.5 $\AA$ resolution. Nature (Lond.), 199, 633.

Muller, C. J. (1960). Separation of the $\alpha$ - and $\beta$-chains of globins by means of starch-gel electrophoresis. ibid., $186,643$.

- (196r). A Comparative Study of the Structure of Mammalian and Avian Haemoglobins, Doctoral Thesis.

, and Jonxis, J. H. P. (1960). Identity of haemoglobin $\mathbf{A}_{2}$. Nature (Lond.), 188, 949.

, and Kingma, S. (I96I). Haemoglobin Zurich $\alpha_{2}{ }^{A} \beta_{2}{ }^{63} A R G$. Biochim. biophys. Acta (Amst.), 50, 595.

Murawski, K., Antonini, E., Brundri, M., Carta, S., Rossi-Fanelli, A., Sorcini, M., Tentori, L., Vivaldi, G., and Wyman, J. (r964). The functional and structural abnormality of hemoglobin $M_{\text {Radom }}$ Proc. Int. Soc. Haemat., 10, 1964.

Murayama, M. (I962a). Chemical difference between normal human haemoglobin and haemoglobin-I. Nature (Lond.), 196, 276.

(1962b). A sub-molecular mechanism of gel formation in sickle cell haemolysate. ibid., 194, 933

- (I964). A molecular mechanism of sickled erythrocyte formation. ibid., 202, 258 .

Na-Nakorn, S., and Minnich, V. (1957). Studies on hemoglobin E. III. Homozygous hemoglobin $\mathrm{E}$ and variants of the lassemia and hemoglobin E. A family study. Blood, 12, 529.

Neeb, H., Beiboer, J. L., Jonxis, J. H. P., Kaars Sijpesteijn, J. A., and Muller, C. J. (r96r). Homozygous Lepore haemoglobin disease appearing as thalassaemia major in two Papuan siblings. Trop. geogr. Med., 13, 207.

Neel, J. V. (1949). The inheritance of sickle cell anemia. Science, r10, 64

- (1956). The genetics of human haemoglobin differences: problems and perspectives. Ann. hum. Genet., 21,1 . - (196I). The hemoglobin genes: a remarkable example of the clustering of related genetic functions on a single mammalian chromosome. Blood, 18, 769 .

Nirenberg, M. W., Jones, O. W., Leder, P., Clark, B. F. C., Sly, W. S., and Pestka, S. (1963). On the coding of genetic information. Cold Spr. Harb. Symp. quant. Biol., 28, 549 .

O'Gorman, P., Allsopp, K. M., Lehmann, H., and Sukumaran, S P. K. (1963). Sickle-cell haemoglobin $\mathrm{K}$ disease. Brit. med. F., 2, 1381 .

Ohya, I. (1963). Abnormal hemoglobins in North Kyshu, Japan, N with special reference to Hb-Kokura and Hb-Fukuoka. $\mathcal{f} a p$. $\mathcal{F}$. C hum. Genet., 8, 23.

Pauling, L., Itano, H. A., Singer, S. J., and Wells, I. C. (I949). Sickle-cell anemia, a molecular disease. Science, 1 10, 543.

Pearson, H. A., Gerald, P. S., and Diamond, L. K. (1959). Thalassemia intermedia due to interaction of Lepore trait with thalas- $\mathcal{N}$ semia trait. Amer. F. Dis. Child., 97, 464.

, and Vertrees, K. M. (I96r). Site of binding of chromium-5r to haemoglobin. Nature (Lond.), 189, rorg.

Penrose, L. S., Smith, S. M., and Sprott, D. A. (1956). On the $\vec{D}$ stability of allelic systems, with special reference to haemoglobins $\frac{\Omega}{T}$ A, S, and C. Ann. hum. Genet., 21, 90. 
Perutz, M. F. (1964). Structure and function of haemoglobin. In Symposium: the structure and activity of enzymes. Proceedings of the rst meeting of the Federation of European Biochemical Societies, p. I4I.

-, Rossmann, M. G., Cullis, A. F., Muirhead, H., Will, G., and North, A. C. T. (1960). Structure of haemoglobin. A threedimensional Fourier synthesis at $5 \cdot 5 \AA$. resolution, obtained by $\mathrm{X}$-ray analysis. Nature (Lond.), 185, 416.

Pierce, L. E., Rath, C. E., and McCoy, K. (1963). A new hemoglobin variant with sickling properties. New Engl. f. Med., 268, 862.

Pisciotta, A. V., Ebbe, S. N., and Hinz, J. E. (1959). Clinical and laboratory features of two variants of methemoglobin $M$ disease. 7. Lab. clin. Med., 54, 73.

Poulik, M. D. (1957). Starch gel electrophoresis in a discontinuous system of buffers. Nature (Lond.), 180, 1477.

Powars, D., Rohde, R., and Graves, D. (1964). Foetal haemoglobin and neutrophil anomaly in the $D_{1}$-trisomy syndrome. Lancet, 1 , 1363.

Pribilla, W. (1962). Thalassämie-ähnliche Erkrankung mit neuem Minor-Hämoglobin (Hb Köln). In Haemoglobin Colloquium, Vienna 1961, ed. H. Lehmann and K. Betke, p. 73. Thieme, Stuttgart.

Pugh, R. P., Monical, T. V., and Minnich, V. (1964). Sickle cell anemia with two adult hemoglobins- $\mathrm{Hb} \mathrm{S}$ and $\mathrm{Hb} \mathrm{G}_{\mathrm{Ph} \text { hladel phia/ }}$ S. Blood, 23, 206.

Ramot, B., Sheba, Ch., Fisher, S., Ager, J. A. M., and Lehmann, H. (1959). Haemoglobin $H$ disease with persistent haemoglobin 'Bart's' in an Oriental Jewess and her daughter; a dual alpha-chain deficiency of human haemoglobin. Brit. med. F., 2, 1228 .

Ranney, H. M. (1954). Observations on the inheritance of sicklecell hemoglobin and hemoglobin C. F. clin. Invest., 33, 1634.

- Jacobs, A. S., Bradley, T. B., Jr., and Cordova, F. A. (1963). $A$ 'new' variant of haemoglobin $A_{2}$ and its segregation in a family with haemoglobin S. Nature (Lond.), 197, 164.

-, O'Brien, C., and Jacobs, A. S. (1962). An abnormal human foetal haemoglobin with an abnormal alpha-polypeptide chain. ibid., 194, 743.

Raper, A. B. (1956). Sickling in relation to morbidity from malaria and other diseases. Brit. med. F., 1, 965.

- Gammack, D. B., Huehns, E. R., and Shooter, E. M. (1960). Four haemoglobins in one individual. A study of the genetic interaction of $\mathrm{Hb}-\mathrm{G}$ and $\mathrm{Hb}-\mathrm{C}$. ibid., 2, 1257.

Reichlin, M., Bucci, E., Antonini, E., Wyman, J., and RossiFanelli, A. (1964). The immunochemical difference between horse oxy- and deoxyhaemoglobin. F. molec. Biol., 9, 785.

Reissman, K. R., Ruth, W. E., and Nomura, T. (196r). A human hemoglobin with lowered oxygen affinity and impaired hemeheme interactions. F. clin. Invest., 40, 1826.

Rigas, D. A., Koler, R. D., and Osgood, E. E. (1955). New hemoglobin possessing a higher electrophoretic mobility than normal adult hemoglobin. Science, 121, 372.

$\longrightarrow$, and - (1956). Hemoglobin $\mathrm{H}$ : clinical, laboratory and genetic studies of a family with a previously undescribed hemoglobin. F. Lab. clin. Med., 47, 51 .

Rimington, C. (1959). Biosynthesis of haemoglobin. Brit. med. Bull., 15, 19.

Robinson, A. R., Robson, M., Harrison, A. P., and Zuelzer, W. W. (1957). A new technique for differentiation of hemoglobin. f. Lab. clin. Med., 50, 745 .

Robinson, E. A., and Itano, H. A. (1960). Identification of the recombinant products of canine and human haemoglobins. Nature (Lond.), 188, 798.

Rosa, J., and Labie, D. (1962). Change in $A_{3}$ haemoglobin due to ß-chain. ibid., 196, 901.

Rossi-Fanelli, A., Antonini, E., and Caputo, A. (1958). Pure native globin from haemoglobin, preparation and some physico-chemical properties. Biochim. biophys. Acta (Amst.), 28, 221.

,-- and - (1964). Hemoglobin and myoglobin. Advanc. Protein Chem., 19, 74.

Rucknagel, D. L., and Chernoff, A. I. (1955). Immunologic studies of hemoglobins. III. Fetal hemoglobin in the circulation of pregnant women. Blood, ro, 1092.

C, and Neel, J. V. (1961). The hemoglobinopathies. In Prog. med. Genet., I, 158.
Sahawi, E., Hunger, H., and Betke, K. (1962). Sporadisches Auftreten von $\mathrm{Hb}-\mathrm{M}$ (Boston type?) in einer mitteldeutschen Familie. Schweiz. med. Wschr., 92, 1090.

Salomon, H., Tatarski, I., Dance, N., Huehns, E. R., and Shooter, E. M. (1964). A new hemoglobin variant found in a Bedouin tribe: hemoglobin 'Rambam'. Proc. of the International Congress of Pacific and Asiatic Pathology Soc. Haifa, 1964. In the press.

Sarabhai, A. S., Stretton, A. O. W., Brenner, S., and Bolle, A. (1964). Co-linearity of the gene with the polypeptide chain Nature (Lond.), 201, 13.

Schmid, R., Brecher, G., and Clemens, T. (1959). Familial hemolytic anemia with erythrocyte inclusion bodies and a defect in pigment metabolism. Blood, 14, 991 .

Schneider, R. G., and Arat, F. (1964). Immunological relationships of various types of haemoglobin. I. Reactions of antisera $A, F$ and 'Bart's' to haemoglobins with various polypeptide chains. Brit. f. Haemat., 10, 15 .

, - and Haggard, M. E. (1964a). An inhomogeneous foetal haemoglobin variant (Texas type). Nature (Lond.), 202, 1346.

-, Haggard, M. E., McNutt, C. W., Johnson, J. E., Jr., Bowman, B. H., and Barnett, D. R. (1964b). Haemoglobin G coushstta : a new variant in an American Indian family. Science, 143, 697.

Schnek, A. G., and Schroeder, W. A. (196I). The relation between the minor components of whole normal adult hemoglobin as isolated by chromatography and starch block electrophoresis. 7. Amer. chem. Soc., 83, 1472.

Schroeder, W. A. (1959). The chemical structure of normal human hemoglobins. Fortschr. Chem. org. NatStaffe, 17, 322.

- (1963). The hemoglobins. Ann. Rev. Biochem., 32, 301.

-, Cua, J. T., Matsuda, G., and Fenninger, W. D. (1962). Hemoglobin $\mathrm{F}_{1}$ : an acetyl-containing hemoglobin. Biochim. biophys. Acta (Amst.), 63, 532.

, and Matsuda, G. (1958). N-terminal residues of human fetal hemoglobin. F. Amer. chem. Soc., 80, 1521 .

-, Shelton, J. R., Shelton, J. B., and Cormick, J. (1962). Further sequences in the $\gamma$-chain of human fetal hemoglobin. Proc. Nat. Acad. Sci. (Wash.), 48, 284.

-, Sturgeon, P., and Bergren, W. R. (1962). Chemical investigation of haemoglobin $\mathbf{F}$ from an individual with persistent foetal haemoglobin. Nature (Lond.), 193, I I61.

Scott, E. M. (1960). The relation of diaphorase of human erythrocytes to inheritance of methemoglobinemia. f. clin. Invest., 39, 1176.

Scott, J. L., Haut, A., Cartwright, G. E., and Wintrobe, M. M. (1960). Congenital hemolytic disease associated with red cell inclusion bodies, abnormal pigment metabolism and an electrophoretic hemoglobin abnormality. Blood, 16, 1239.

Shepard, M. K., Weatherall, D. J., and Conley, C. L. (1962). Semi-quantitative estimation of the distribution of fetal hemoglobin in red cell populations. Bull. fohns Hopk. Hosp., 110, 293.

Sherman, I. J. (1940). The sickling phenomenon, with special reference to the differentiation of sickle cell anemia from the sickle cell trait. ibid., 67, 309 .

Shibata, S., and Iuchi, I. (1962). Agar gel electrophoresis for rapid separation of hemoglobin. Proc. Int. Soc. Haemat., Tokyo, 1960, 8 (2), 1239.

-, - Miyaji, T., Ueda, S., and Takeda, I. (1963). Hemolytic disease associated with the production of abnormal hemoglobin and intraerythrocytic Heinz bodies. Acta haemat. fap., 26, I64.

- - Ueda, S., Miyaji, T., and Takeda, I. (I962b). Agar gel electrophoresis of the hybrid of canine and human haemoglobins: a simple convenient means for the determination of chain anomaly. ibid., 25, 675 .

, Miyaji, T., Iuchi, I., Ueda, S., and Takeda, I. (1964). Hemoglobin Hikari $\left(\alpha_{2}^{A} \beta_{2}^{\prime 1}{ }_{A B D N H 2}\right)$ : a fast-moving hemoglobin found in two unrelated Japanese families. Clin. chim. Acta, 10, ror. $,-1,-1,-$ Kimura, N., and Kodama, S. (1962a). Hemoglobin M-Kurume: its identity with hemoglobin $M$ Saskatoon. Acta haemat. Fap., 25, 690 .

Shooter, E. M., Skinner, E. R., Garlick, J. P., and Barnicot, N. A. (1960). The electrophoretic characterization of haemoglobin $G$ and a new minor haemoglobin, G, . Brit. F. Haemat., 6, 140.

Silvestroni, E., and Bianco, I. (1958). Associazione di Hb G e microcitemia in due membri di una famiglia italiana del ferrarese. Policlinico, Sez. prat., 65, 203.

, and - (1963). A new variant of human fetal hemoglobin: Hb Froma. Blood, 22, 545 . 
- , and Brancati, C. (1963). Haemoglobins $N$ and $P$ in Italian families. Nature (Lond.), 200, 658.

Singer, K., Chernoff, A. I., and Singer, L. (1951). Studies on abnormal hemoglobins. I. Their demonstration in sickle-cell anemia and other hematologic disorders by means of alkali denaturation. Blood, 6, 413.

-, and Fisher, B. (I952). Studies on abnormal hemoglobins. V. The distribution of type $S$ (sickle cell) hemoglobin and type $F$ (alkali resistant) hemoglobin within the red cell population in sickle cell anemia. ibid., 7, 1216.

, Kraus, A. P., Singer, L., Rubinstein, H. M., and Goldberg, S. R. (1954). Studies on abnormal hemoglobins. X. A new syndrome: hemoglobin C-thalassemia disease. ibid., 9, 1032. , Singer, L., and Goldberg, S. R. (1955). Studies on abnormal hemoglobins. XI. Sickle cell-thalassemia disease in the Negro. The significance of the $\mathbf{S}+\mathbf{A}+\mathbf{F}$ and $\mathbf{S}+\mathbf{A}$ patterns obtained by hemoglobin analysis. ibid., 10, 405 .

Smith, E. W., and Torbert, J. V. (1958). Study of two abnormal hemoglobins with evidence for a new genetic locus for hemoglobin formation. Bull. fohns Hopk. Hosp., 102, 38.

Spaet, T. H., Alway, R. H., and Ward, G. (1953). Homozygous type 'c' hemoglobin. Pediatrics, 12, 483.

Steiner, M., Baldini, M., and Dameshek, W. (1964). Studies of haem synthesis in thalassaemia, refractory sideroblastic anaemia and the di Guglielmo Syndrome. Proc. int. Soc. Haemat., 10. In the press.

Stern, C. (1960). Principles of Human Genetics, 2nd ed. W. H. Freeman, San Francisco and London.

Sturgeon, P., Schroeder, W. A., Jones, R. T., and Bergren, W. R. (1963). The relation of alkali-resistant haemoglobin in thalassaemia ard abnormal haemoglobin syndromes to foetal haemoglobin. Brit. f. Haemat., 9, 438.

Swenson, R. T., Hill, R. L., Lehmann, H., and Jim, R. T. S. (1962). A chemical abnormality in hemoglobin $G$ from Chinese individuals. F. biol. Chem., 237, 1517.

Teale, F. W. J. (1959). Cleavage of the haem-protein link by acid methylethylketone. Biochim. biophys. Acta (Amst.), 35, 543 .

Thompson, G. R., and Lehmann, H. (1962). Combinations of high levels of haemoglobin $F$ with haemoglobins $A, S$, and $C$ in Ghana. Brit. med. F., I, 1521.

Thompson, R. B., Mitchener, J. W., and Huisman, T. H. J. (1961) Studies on the fetal hemoglobin in the persistent high $\mathbf{H b}-\mathrm{F}$ anomaly. Blood, 18, 267.

Tondo, C. V., Salzano, F. M., and Rucknagel, D. L. (1963) Hemoglobin Porto Alegre, a possible polymer of normal hemoglobin in a Caucasian Brazilian family. Amer. F. hum. Genet., 15, 265.

Townes, P. L., and Morrison, M. (1962). Investigation of the defect in a variant of hereditary methemoglobinemia. Blood, $19,60$.

Tuchinda, S., Rucknagel, D. L., Minnich, V., Boonyaprakob, U., Balankura, K., and Suvatee, V. (I964). The coexistence of genes of hemoglobin $E$ and $\alpha$-thalassaemia in Thais, with resultant suppression of hemoglobin E synthesis. Amer. F. hum. Genet., 16, 311 .

Vandepitte, J., and Delaisse, J. (1957). Sicklémie et paludisme. Ann. Soc. belge Méd. trop., 37, 703.

Van Vliet, G., and Huisman, T. H. J. (1964). Changes in the haemoglobin types of sheep as a response to anaemia. Biochem. f., 93,401 .

Vella, F., Ager, J. A. M., and Lehmann, H. (1959). New variant of human foetal haemoglobin. Nature (Lond.), 183, 31.
Wells, R. H. C., Ager, J. A. M., and Lehmann, H. (1958). A haemoglobinopathy involving haemoglobin $\mathrm{H}$ and a new (Q) haemoglobin. Brit. med. F., 1, 752.

Vinograd, J., and Hutchinson, W. D. (1960). Carbon-14 labelled hybrids of haemoglobin. Nature (Lond.), 187, 216.

Wasi, P., Na-Nakorn, S., and Suingdamrong, A. (1964). Thalassaemia-Hb.-H in Thailand: a genetical study. Proc. $X$ th Cong. int. Soc. Haemat. In the press.

Weatherall, D. J., and Baglioni, C. (1962). A fetal hemoglobin variant of unusual genetic interest. Blood, 20, 675 .

- and Boyer, S. H., IV (1962). Evidence for the genetic identity of alpha chain determinants in hemoglobins $A, A_{2}$, and $F$. Bull. Fohns Hopk. Hosp., 110, 8.

- Sigler, A. T., and Baglioni, C. (1962). Four hemoglobins in each of three brothers. Genetic and biochemical significance. ibid., III, 143 .

Went, L. N., and MacIver, J. E. (1958). An unusual type of hemoglobinopathy resembling sickle cell-thalassemia disease in a Jamaican family. Blood, 13, 559 .

Westendorp Boerma, F., and Huisman, T. H. J. (I964). Serological investigations of human hemoglobins. II. Antibodies produced by isolated human hemoglobin types with known structural differences. F. Lab. clin. Med., 63, 264 .

- - - and Mandema, E. (1960). Serological investigations of some human and animal hemoglobins by agar gel-diffusion method. Clin. chim. Acta, 5, 564 .

Wheeler, J. T., and Krevans, J. R. (I96I). The homozygous state of persistent fetal hemoglobin and the interaction of persistent fetal hemoglobin with thalassemia. Bull. fohns Hopk. Hosp., 109, 217.

White, J. C., and Beaven, G. H. (1959). Foetal haemoglobin. Brit. med. Bull., 15, 33.

- Ellis, M., Coleman, P. N., Beaven, G. H., Gratzer, W. B., Shooter, E. M., and Skinner, E. R. (I960). An unstable haemoglobin associated with some cases of leukaemia. Brit. f. Haemat., 6, 171 .

Wilson, S., and Smith, D. B. (1959). Separation of the valylleucyl- and valyl-glutamyl-polypeptide chains of horse globin by fractional precipitation and column chromatography. Canad. F. Biochem., 37, 405 .

Winterhalter, K. H., and Huehns, E. R. (1963). Free globin in red cells. F. clin. Invest., 42, 995.

- and - (1964). Preparations, properties and specific recombination of $\alpha \beta$ globin subunits. F. biol. Chem., 239, 3699.

Wintrobe, M. M. (196I). Clinical Hematology, sth ed. Kimpton London.

Yakulis, V. J., Heller, P., Josephson, A. M., and Singer, L. (1960). Rapid demonstration of $\mathrm{A}_{2}$ hemoglobin by means of agar gel electrophoresis. Amer. F. clin. Path., 34, 28.

Yanofsky, C., Carlton, B. C., Guest, J. R., Helinski, D. R., and Henning, U. (1964). On the colinearity of gene structure and protein structure. Proc. nat. Acad. Sci. (Wash.), 51, 266.

Zuckerkandl, E. (1964). Controller-gene diseases. The operon model applied to $\beta$-thalassaemia, familial fetal hemoglobinemia and the normal switch from the production of fetal hemoglobin to that of adult hemoglobin. f. molec. Biol., 8, 128 .

Zuelzer, W. W., and Kaplan, E. (1954). Thalassemia-hemoglobin C disease. Blood, 9, ro47.

- Robinson, A. R., and Booker, C. R. (196I). Reciprocal relationship of hemoglobins $A_{2}$ and $F$ in beta chain thalassemias, a key to the genetic control of hemoglobin F. ibid., 17, 393. 